DOI: 10.20520/Jel-Kep.2015.3.25

\author{
Fokasz Nikosz ${ }^{a, b}$, Tóth Gergely ${ }^{a}$, Micsinai István ${ }^{a}$, \\ Jelenfi Gábor ${ }^{a}$, Elöd Zoltán ${ }^{a}$ \\ ${ }^{\mathrm{a}}$ MTA-ELTE Peripato Kutatócsoport, \\ ${ }^{\mathrm{b}}$ Alexander S. Onassis Public Benefit Foundation
}

\title{
KAMPÁNY ÉS VALÓSÁGKONSTRUKCIÓ \\ A 2010-es és a 2014-es választási kampányok összehasonlító elemzése a NOL és az MNO oldalakon megjelent kampány-témák dinamikája alapján
}

\begin{abstract}
Absztrakt
Tanulmányunk közvetlen célja, hogy feltárjuk a 2010-es és 2014-es magyarországi parlamenti választási kampányok legföbb médiadinamikai jellemzöit. Elemezzük a tömegmédia valóságkonstrukciójának legföbb empirikus tényeit, rendszerszerü strukturális jegyeit, és a kampányokhoz kapcsolódó dinamikai finomhangolását. Tanulmányunk az elsö lépés azon törekvésünkben, hogy egy empirikus médiadinamikai vizsgálatot összekapcsoljunk Niklas Luhmann-nak a tömegmédia valóságkonstrukciójára vonatkozó elméletével.
\end{abstract}

Kulcsszavak: médiadinamika, kampány, parlamenti választások

\section{Bevezetés}

Közismert, hogy Niklas Luhmann abbéli törekvésében, hogy a modern társadalom vizsgálatára alkalmas általános elméletet állítson elő egy rendkívül absztrakt koncepcióval, egyesek szerint egyenesen - a tudományos paradigmák átfogó jellegét megközelítő - szuperteóriával ${ }^{1}$ állt elő. Világos, hogy egy ilyen elméletnek bármiféle empíriával való tesztelése igazi kihívás minden empirikus kutató számára. A tömegmédia valósága címü müvében azonban Luhmann, ha érdemben nem is csökkenti elmélete absztrakciós szintjét, vizsgálódása körét mégis leszükíti annyira, hogy esélyt kínáljon, ha nem is a tesztelésre, de legalább az empíriával való valamiféle összekapcsolásra.

\footnotetext{
${ }^{1}$ Lásd még: Weber (2003).
} 
Ilyen kapcsolódási pontok felmutatására törekszünk mi is ${ }^{2}$ a jelen tanulmányban. Vizsgálódási terepül olyan területet - a 2010-es és 2014-es magyarországi választási kampányoknak a hírközlő média egy szegmensében történő megjelenése összehasonlító elemzését - választottuk, amelynek kutatása mindenféle luhmanni indíték nélkül is számot tarthatna érdeklődő figyelmünkre.

Tanulmányunkat az általunk összegyüjtött adatbázis egyszerü, leíró statisztikai elemzésével indítjuk. Innen próbálunk fokozatosan, az empíria egyre elmélyültebb vizsgálatára támaszkodva a luhmanni elvontságnak legalább az alsó régióihoz kapcsolódási pontokat találni.

\section{Eseményképzés, közbeszédi témák}

Lármás világban élünk. S ehhez a tömegmédia is hozzáteszi a magáét. Hatalmas médiavállalkozások rendezkedtek be arra a várakozásra, hogy folyamatosan találnak kellő nyersanyagot a hírgyártáshoz. S csakugyan a hírek/tudósítások már nem is naponta, szinte percenként igénylik figyelmünket. A hírek azonban amilyen gyorsan keletkeznek, ugyanolyan gyorsan el is pukkannak. „Semmi sem régibb, mint egy tegnapi újság” - mondta Mark Twain (idézi A. Bandy 2014). A ma híre holnapra már nem az.

De nem csak a kínálat folyamatos, a kereslet is az. Jó ideje olyan világban élünk, amelyben „mindenkinek szüksége van hírekre.” (Molotch-Lester 2007: 413) Már kétszáz évvel ezelött is megállapíthatták, hogy a „hírek iránti csillapíthatatlan étvágy a köszönés új, általános formáját termelte ki, amelyet ma már barátok és idegenek egyaránt szívesen használnak: Mi újság?" (idézi J. Alexander 2007: 160)

A médiumok persze nem várnak passzívan arra, hogy majd csak történik valami. „Azt, hogy minek van hírértéke, a média dönti el.” (Murray 2007: 452) E szelekció nélkül a média egyszerüen „mindennek ki volna szolgáltatva, ami adódik.” (Luhmann 2008: 26) Bár a „valóságnak a tömegmédiában való bemutatását legtöbbször úgy tekintik, mint a valóság egy szeletének tükörképét" (Kepplinger 2007: 391), egyes szerzők a hetvenes években a hírek olyan, általunk is osztott megközelítésmódját dolgozták ki, amely szerint a hír a „hírterjesztök, hírösszeállítók és hírfogyasztók gyakorlati, célirányos és kreatív tevékenységének - szerintünk nem mindig szándékolt - eredménye”, s ennyiben „konstruált realitás.” (MolotchLester 2007: 413)

A továbbiakban a társadalmi vagy természeti történéseket, eseteket terminológiailag is megkülönböztetjük az ezekről tudósító, ezekböl képzett média eseményektöl. A média által gyakorolt hír/nem hír szelekció legelemibb kritériuma, hogy a hírnek újnak kell lennie. Az újdonságok felismeréséhez azonban ismert kontextusokra van szükség

Az eseményképzés ezen folyamatának állomásain az adott történést, esetet „észlelik, összeállítják jellemző jegyeit, s beillesztik az előzmények és a jövőben várható események kontextusába” (Molotch-Lester 2007: 413) „Időnként alkalom nyílik arra is, hogy beszámoljanak hasonló esetekről, vagy akár események egész soráról.” (Luhmann 2008: 44) Az egyszeri eseményeknek ez az összekapcsolása többé-kevésbé állandósult közbeszédi témákat teremthet. Ezen témák formálódó identitásának legnyilvánvalóbb jelei az olyan hívószavak mint például „Csernobil”, „olajszőkités”, „9/11”, „Öszöd” „Olaszliszka” - felbukkanása, amelyek akár hosszabb idő távlatából is képesek egyértelmüen megnevezni, megjelölni a kérdéses közbeszédi témákat.

Tanulmányunk empirikus részében éppen e hívószavak felbukkanásának tényére támaszkodunk.

\footnotetext{
${ }^{2}$ Lásd még: Görke - Scholl (2006).
} 


\section{Napirendek}

A sajtótémák vizsgálatával foglalkozó korábbi kommunikációs és empirikus médiakutatások arra a megállapításra jutnak, hogy a kampányok során a média, ha nem is változtatja meg jelentősen az attitüdöket, a szavazók tanulnak az óriási információtömegből. Méghozzá egyenesen arányosan a tömegmédia által az egyes témákra helyezett (mennyiségi és minőségi) hangsúllyal. A média napirend-kijelölő tevékenysége alakítja ki az egyes témák iránti érdeklődés erősségét egyrészt a közvélemény, a politikai közbeszéd, másrészt a politikusok, a közpolitikai szféra számára.

A napirend-elemzések fontos megállapítása, hogy a kampányhírek egy jelentős része nem a fö politikai témákkal vagy a szereplökkel, hanem magának a kampánynak az elemzésével foglalkozik (szavazás, kampány, elemzés). A médiában megjelenő fő témák rangsora és a választók által felállított fontossági sorrendek (közvélemény) között rendkívül erōs összefüggés, szoros pozitív korreláció mutatható ki. Az egyes pártok szavazóink véleménye és az összes hír tartalma közötti korreláció alapján megállapítható, hogy általában az emberek nem figyelnek jobban azokra a hírekre, amelyek saját pártjukat, jelöltjeiket érintik. Ezzel magyarázható, hogy a média témakijelölő funkciója erősebben érvényesül, mint a szelektív percepció hatása. A különböző médiumok között is nagy az egyetértés a kampány fontos témáit illetően. Ahogy eltávolodunk a kampány fö eseményeitől, amelyekben mindenki egyetért, megnő az egyéni értelmezés tere. A különbségek egyrészt a médiumok alapvető eltérő jellemzőivel, illetve értékrendjével, előítéleteikkel magyarázhatóak.

A korai kommunikációs modellek, a médiának erős és direkt, lineáris hatását feltételezték. Ezzel szemben a későbbi iskolák, mint a kétlépcsős modell vagy a társadalmi diffúzió, a napirendkijelölés (agenda-setting) inkább a gyengébb, nem közvetlen hatást, és a különböző hatások kölcsönös kapcsolódását, konvergenciáját állapították meg. (Rogers-Kincaid 1981: 32-65)

A tematizációval kapcsolatos kutatások nem mindegyike szorítkozik a megjelenő témák egyszerü rangsorolására. Sok esetben megkülönböztetnek három napirendet, a közvéleményét, a politikáét és a médiáét, de kevés olyan kutatás van, amely a napirend komplexitását, a három terület egymásra hatását, dinamikus rendszerét elemezné. (Török 2005: 167-176) A média napirend esetében a legdöntöbb momentumok a láthatóság (mennyiség, fontosság), a hír jelentősége, relevanciája és vegyértéke, azaz pozitív vagy negatív hangvétele, megítélése. A közvélemény és a politika napirendjét más tényezők határozzák meg, azonban a három terület egymással erős kölcsönhatásban van. (Manheim 1986: 499-516)

A napirend-tanulmányok másik fontos ismérve, hogy általában egy adott időszak keresztmetszeti vizsgálatára vállalkoznak, és csak nagyon kevés kutatás dolgozik longitudinális adatokkal. A kutatások a média és a másik két napirend, valamint a különböző orgánumok között komoly hasonlóságot, kongruenciát állapítottak meg. (Baumgartner-Jones 1993, 2002, 2004) A szakpolitikában és a közvéleményben az ügystruktúra eltérését azzal magyarázzák, hogy a közvélemény tömöríti, összegyüjti a témákat, míg pl. a parlament egyszerre rengeteg üggyel tud foglalkozni. A „punctuated equilibrum” modell szerint a lassú inkrementális változásokat mutató egyensúlyi állapotokat drámai események által kiváltott, rövid ideig tartó, jelentős szakpolitikai változások szakítják meg.

A fenti megállapításokat megerősíti egy másik kutatás alapján készült modell is, amely szerint azok a (fontos) társadalmi problémák jelennek meg a szakpolitikában - és adott esetben változásokat, reformokat is eredményezhetnek -, amelyeket a média is napirendre tüz. És az ügyhöz kapcsolódó szenzációk, újdonságok a téma tálalását (framing) is megváltoztathatják. (Dearing-Rogers 1996) A szerzők a három napirendi elemet modelljükben kiegészítették a személyes tapasztalatok és az emberek közötti interperszonális kommunikáció hatásával és a téma vagy az esemény „valódi fontosságával”, valamint a média napirendjére ható külső 
ingerekkel. A külső hatások a médiatulajdonosok, -döntéshozók (a kapuőrök) befolyása, értékei, érdekei, illetve az egyes hírek látványossága. A tanulmány azt is megállapítja, hogy a valóban fontos ügyek nem automatikusan kerülnek a média látókörébe, sokkal inkább a téma percepciója határozza meg ezt a folyamatot. A modell azt mutatja be, hogy a média (napirendjén keresztül - lásd pl: McCombs-Shaw 2007: 252-260) részben közvetlenül, de elsősorban közvetve, a közvéleményen keresztül képes hatni a politikára, miközben a szakpolitika (napirendjén keresztül) visszahat a médiára is.

\section{Empirikus elemzés}

A napirend-kutatások alapján - de akár saját választói emlékeinkre támaszkodva is - könnyüszerrel nevesíthetjük a 2010-es és 2014-es kampányidőszakok ${ }^{3}$ leglátványosabb közbeszédi témáit. A fenti ismeretek persze legfeljebb csak a kiindulópontot jelenthették a 2010-es és 2014-es kampányidőszak föbb témáinak kiválasztásában. A 2010-es kampány esetében Magyarország Politikai Évkönyvének 2009-es és 2010-es kiadását, valamint Szabó Gabriella, Mihályffy Zsuzsanna, Kiss Balázs 2011-ben megjelent Kritikus kampány címü munkáját használtuk. A 2014-es kampány esetében az adatgyüjtés idején ilyen adatbázis nem állt rendelkezésünkre, ezért a HVG releváns lapszámait felhasználva állítottuk össze a témák listáját. Utóbb ezt több lépcsőben kiegészítettük a közelmúltban lezajlott kampány szerintünk legfontosabb közbeszédi témáival. A mintegy kétszáz témát jellegzetes hívószavak - például „hln1”, „végkielégítés” „rezsicsökkentés”, „békemenet”, „válság” - vagy összetettebb kifejezések - úgy, mint „,pénzügyi válság”, „,szociális kártya”, „Zuschlag-per”, ,,keleti nyitás”, „bajai videó" - illetve a párt- és politikusnevek segítségével ragadtuk meg.

Mindkét kampányidőszakra külön-külön összeállítottuk a hívószavak listáját, majd összegyüjtöttük az összes olyan cikket, amelyek tartalmazták a hívószavak valamelyikét. A vizsgálatot a Magyar Nemzet és a Népszabadság online oldalaira szükítettük. ${ }^{4}$

Az általunk vizsgált két kampányidőszakban, s a két médiumban összesen 95.182 olyan cikket találtunk, amelyben szerepeltek azok a hívószavak, amelyeket mi kampánytémaként azonosítottunk. A vizsgált közbeszédi témák dinamikájának a két lap és a kampányidőszakok közötti összehasonlíthatósága érdekében relatív mutatószámokat is képeztünk. Egy adott témában, valamely napon megjelent cikkek számát, az azon a napon az általunk vizsgált valamennyi témában megjelent cikkek összes számához viszonyítottuk. Ezt a mutatószámot a továbbiakban napi relatív-cikkszámként emlegetjük és százalékban mérjük.

A két lapban együttvéve 2009-2010-ben átlagosan 234.8, míg 2013-2014-ben 191.9 cikk jelent meg. Újságok és időszakok szerint külön-külön vizsgálva a naponta megjelent cikkek száma 7 cikktől (a NOL-ban 2013-14 folyamán), 213 cikkig terjedt (az MNO-ban 2009-10 során), a napi cikkszámok átlaga pedig minimum 82.7 (NOL 2013-14), maximum 140.8 (MNO 2009-10) cikk volt. A naponta megjelenő cikkek számának alakulása tehát meg-

3 A kampányidőszak nyitányát szeptember 1-vel datáltuk, elemzésünk 2010-ben és 2014-ben is ekkortól kezdődik. A 2010-es választásokat a köztársasági elnök 2010. január 22-én tüzte ki, ekkor indult a hivatalos kampány. Az akkor még kétfordulós parlamenti választások két időpontja pedig 2010. április 11. és április 25. voltak. 2014-ben a választás az új alaptörvény elöírásai szerint egyfordulós volt. Ezt a választást a köztársasági elnök 2014. január 15-én április 6-ára tüzte ki. A két kampány időtartama így öt nappal eltérne egymástól, azért az általunk vizsgált kampányidőszak zárását április 11-re datáltuk.

${ }^{4}$ Tudatában vagyunk annak, hogy az utóbbi években mindkét médium szerepe csökkent a politikai közbeszéd tematizálásában. Meggyőződésünk ugyanakkor, hogy jelen elemzésünkkel előkészítjük a média valóságkonstrukciójának komplexebb vizsgálatát is. 
lehetősen hektikusnak bizonyult. A cikkek napi számának hétnapos mozgóátlagait tartalmazó diagram (1. ábra) már bizonyos szabályszerüséget, szezonalitást sugall. A november közepe tájától Karácsonyig terjedő időszak rendre megismétlődő enyhe lejtmenete után KarácsonyÚjév időszaka visszatérően erős apályt mutat. Az általunk mért médiaaktivitás január közepére érte el a kampányüzemi szintet, amelynek lendületét rendre március 15 -dike ${ }^{5}$ környéke törte meg.

1. ábra

A kampánytémákat tartalmazó cikkek napi számának hét napos mozgóátlagai

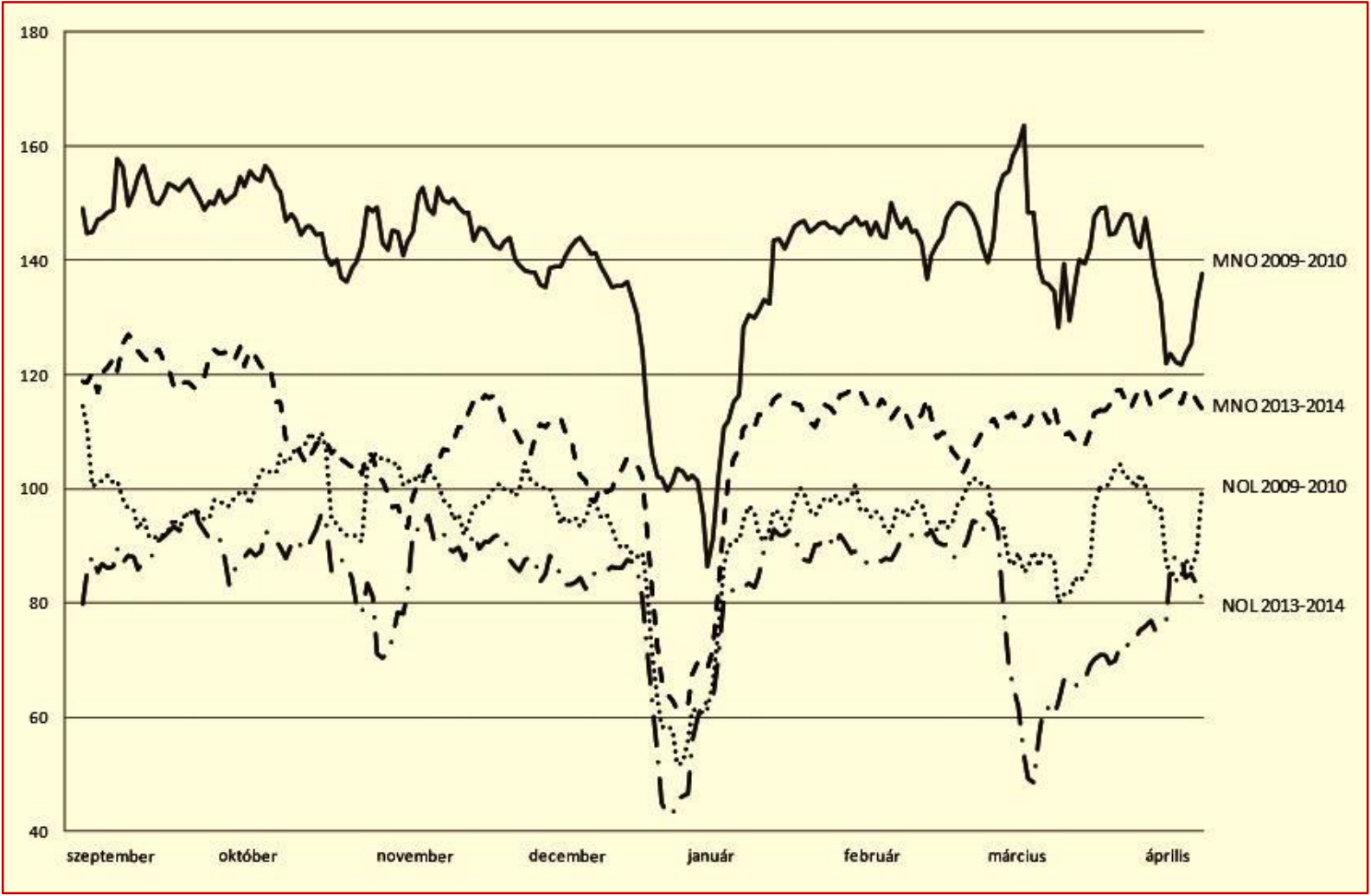

Nem értékelnénk persze túl a fenti áttekintő megállapításokat. Világos, hogy a hívószavak kiválasztása - akkor is, ha számos független forrásra támaszkodtunk - szubjektív elemeket is tartalmaz. Ez rajta hagyja nyomát azon, hogy egyáltalán mit láthatunk, mérhetünk. E sajátos megfigyelöi pozíció hatása akkor is megmarad, ha a szubjektivitás hatását a hívószavak számának növelésével igyekeztünk csökkenteni. Ez utóbbi viszont növelte az esélyét annak, hogy egy cikkben akár több hívószó is jelen legyen, az egyes témák között tehát akár többszörös átfedés is lehet.

A névadás kétségtelenül teremtő aktus. Egy meghonosodott hívószó biztos jele egy közbeszédi téma létezésének. A „rezsicsökkentés”, „,békemenet”, „Zuschlag-per”, „keleti nyitás”, „,bajai videó” a kampányidőszak kétségkívül létező közbeszédi témái voltak. Mérési eljárásunk azonban csavar egyet ezen a tényen. Önmagában az, hogy bizonyos szavak előfordulnak egy cikkben - márpedig mi ezt mérjük - nem garantálja azt, hogy a kérdéses cikk éppen az adott kifejezéssel jelölt közbeszédi témáról szól.

5 Az MNO 2014-es március 15-i aktivitása kivételnek számít, a 2010-es kampány-időszakvégi mélypont pedig annak volt köszönhető, hogy a Húsvét abban az évben április 4-re esett. 
Ráadásul az általunk alkalmazott hívószavak státusza ebben a tekintetben rendkívül eltérö. Tudható, hogy egyes hívószavak egészen konkrét eseményekre utalnak, s feltételezhetö, hogy az ezeket a szavakat tartalmazó cikkek nagy valószínűséggel éppen ezekkel az eseményekkel kapcsolatos hírekröl tudósítanak. Különösen így van ez, ha a kérdéses tudósítássorozatot úgynevezett „kulcsesemények”, többnyire személyek vagy szervezetek körül kitörő botrányok - mint történt például a „kötcsei beszéd”, „Kubatov lista”, „Zuschlag”, „Veritas”, „szobordöntés” témák esetében - indítják el. Ezek ugyanis erős „,szívóhatást fejtenek ki, és több korábbi eseményt és aspektust szippantanak magukba."7

Ezzel szemben a „választás” „kampány”, „program”, „válság” vagy akár a „Fidesz”, „MSZP” kifejezések inkább gyüjtőfogalomként müködnek. Könnyen előfordulhat, hogy egyszerre több témát is magukba foglalnak, így egyáltalán nem magától értetődő, hogy ezek a cikkek valójában miről is szólnak. Emiatt, s a korábban már említett átfedések miatt csaknem biztosak lehetünk abban, hogy a fenti kifejezéseket tartalmazó cikkek egy bizonyos számunkra pillanatnyilag ismeretlen - hányada nem egyedül, vagy egyáltalán nem az adott hívószóval jelzett közbeszédi témáról tudósít.

E probléma megoldásához azonban, ha minimális mértékben is, de a cikkek tartalomelemzésének irányába kellene elmozdulnunk. Ez meghaladja jelen tanulmányunk kereteit. Vizsgálatainkat a továbbiakban ezért annak tudtával végezzük, hogy a hívószavakra támaszkodó mérésünk egy immanens problémát hordozz magában. Ezzel együtt úgy véljük, így is marad tere annak, hogy a kampánytémák dinamikája terén érvényes megállapításokat tehessünk.

\section{Az alapstruktúra}

Kiindulásként először madártávlatból vetünk pillantást a kampánytémák dinamikájára. Ha az egyes témák napi relatív-cikkszámaiból (az MNO-ban példul a „választás” relatív cikkszáma 2009. szeptember elsején 8.6-nak, másodikán 4.6-nak, harmadikán 10.0-nek, negyedikén pedig 12.3-nak adódott) előállítjuk a kérdéses kampánytémák időben kumulatív relatív-cikkszámait ábrázoló diagramokat (az előbbi példánál maradva a kumulatív relatív-cikkszám elsején marad 8.6, másodikán már 13.2-re növekszik, míg harmadikán 23.2 és így tovább), akkor mindenekelött egy újságonként és kampányidőszakokként is megismétlődő kettős szerkezet egyöntetü dominanciája jelenik meg elöttünk.

A teljes kampányidőszakban maximum 500 kumulatív relatív-cikkszámmal rendelkező témák áttekinthetetlen talapzatából a leggyakrabban szereplö témák legyezőszerüen szétnyíló alakzata emelkedik ki. Ráadásul e témák kumulatív relatív-cikkszám szerinti rangsora feltűnő, a kampányidőszakoktól és a vizsgált újságoktól is független, stabilitást mutat (lásd 2a-b. és 3a-b. ábra). A ,választás”, a „program”, a „vita”, a „kampány” vagy a pártok közül a „Fidesz” és az „MSZP” - tehát a kampányidőszak leginkább technikainak tekinthető témái - minden esetben az említési rangsor élmezőnyében helyezkednek el. Figyelemre méltó, hogy 2014-re még a „válság” kifejezés is csak néhány helyet csúszott vissza a rangsorban, miközben azt gondolhattuk volna, hogy a 2008-as hitelválság és annak hazai következményei miatt a 2010es kampányban jóval előkelöbb helyre kerülhet. ${ }^{8}$

${ }^{6}$ Hans Matthias Kepplinger 2007: 397.

7 Hans Matthias Kepplinger 2007: 396.

${ }^{8}$ Megjegyezzük, hogy a 2., valamint a későbbiekben a 3., 8., 9., 10., 11. és 15. ábrák alján megfigyelhető fekete vonalak is tényleges közbeszédi témák grafikonjai. Nem nevesítjük őket, mert ezzel érzékeltetnénk a közbeszédi témák tömeges jellegét. Az ábrákon éppen nevesített témák ebből a "tématengerből" lettek kiemelve. Ezt a szelekciós folyamatot kívánjuk érzékeltetni azzal, hogy ennek a tengernek egy részét ott hagytuk az ábrák alján. 


\section{2(a-b). ábra}

2a) 2010 NOL: kampánytémák kumulatív gyakoriságának idősorai

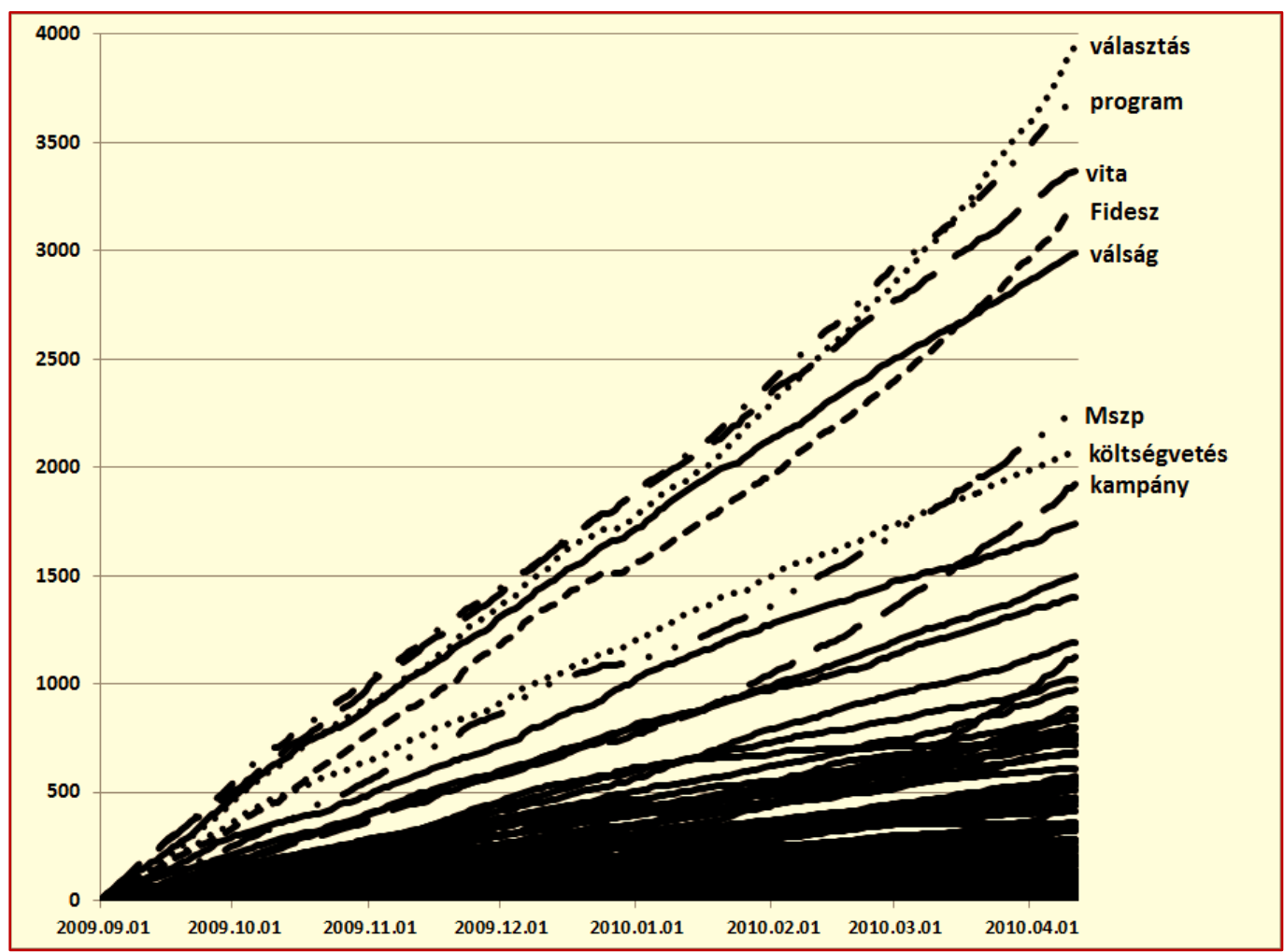

2b) 2010 MNO: kampánytémák kumulatív gyakoriságának idösorai

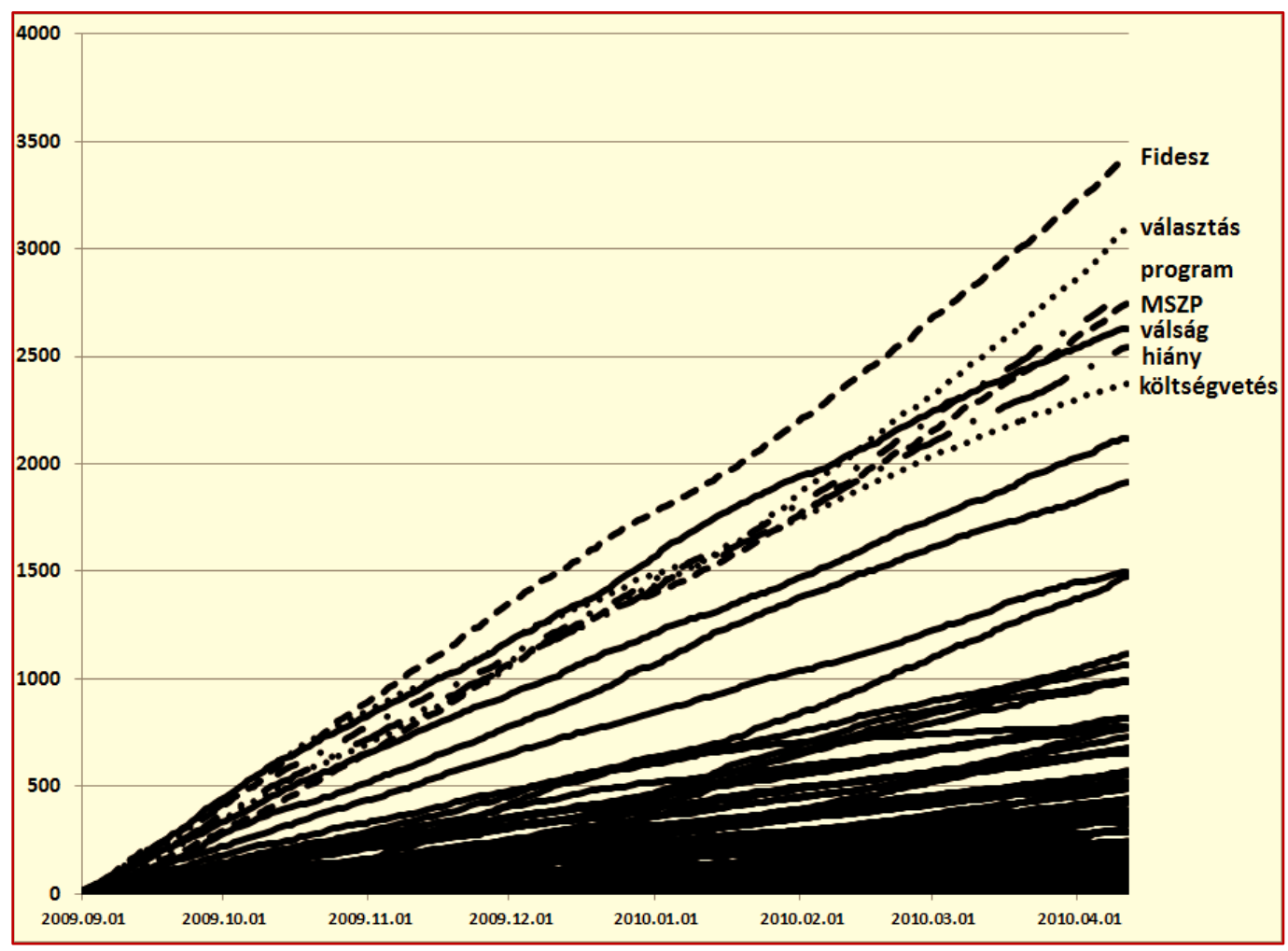


3(a-b). ábra

3a) 2014 NOL: kampánytémák kumulatív gyakoriságának idősorai

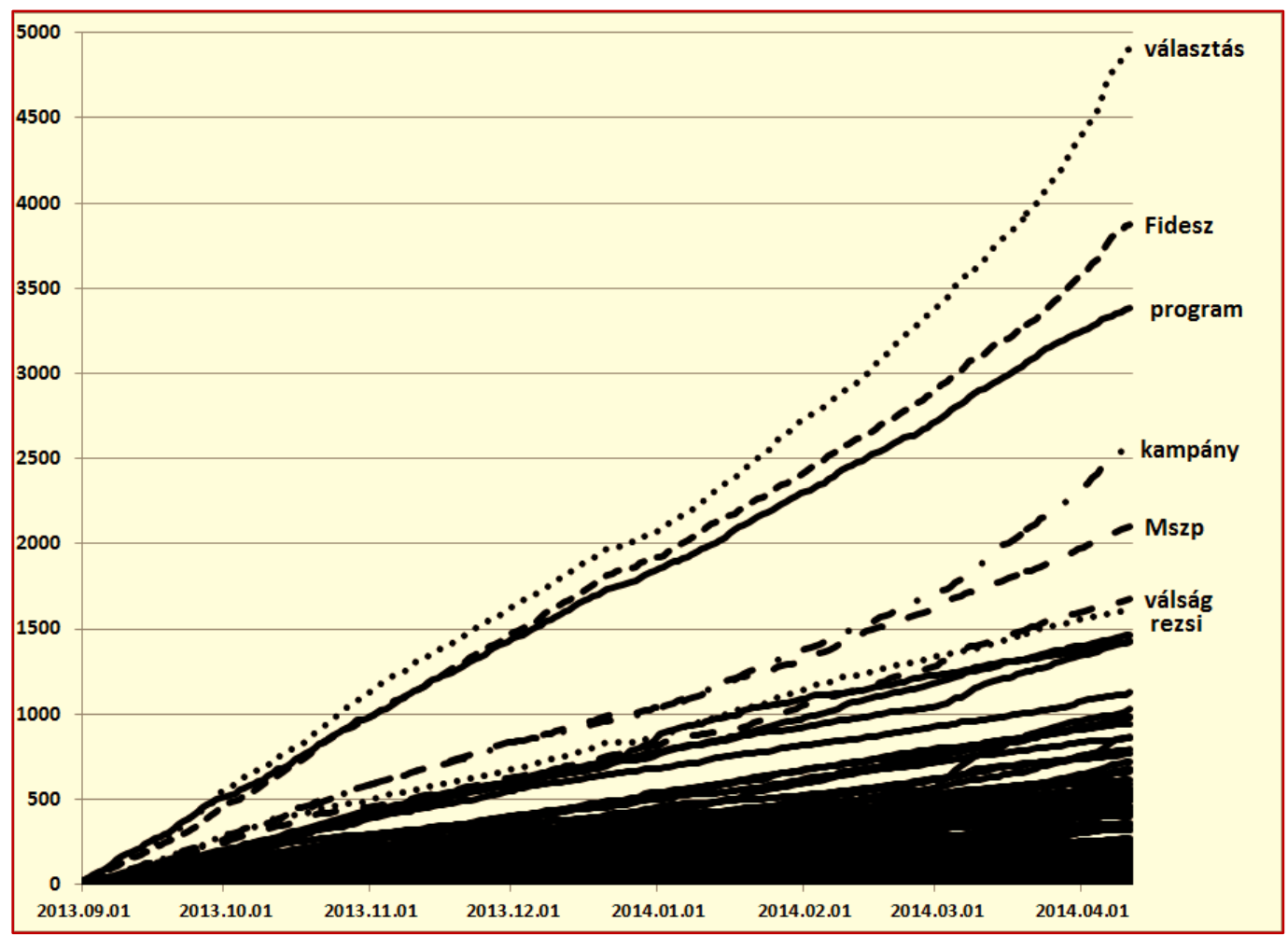

3b) 2014 MNO: kampánytémák kumulatív gyakoriságának idösorai

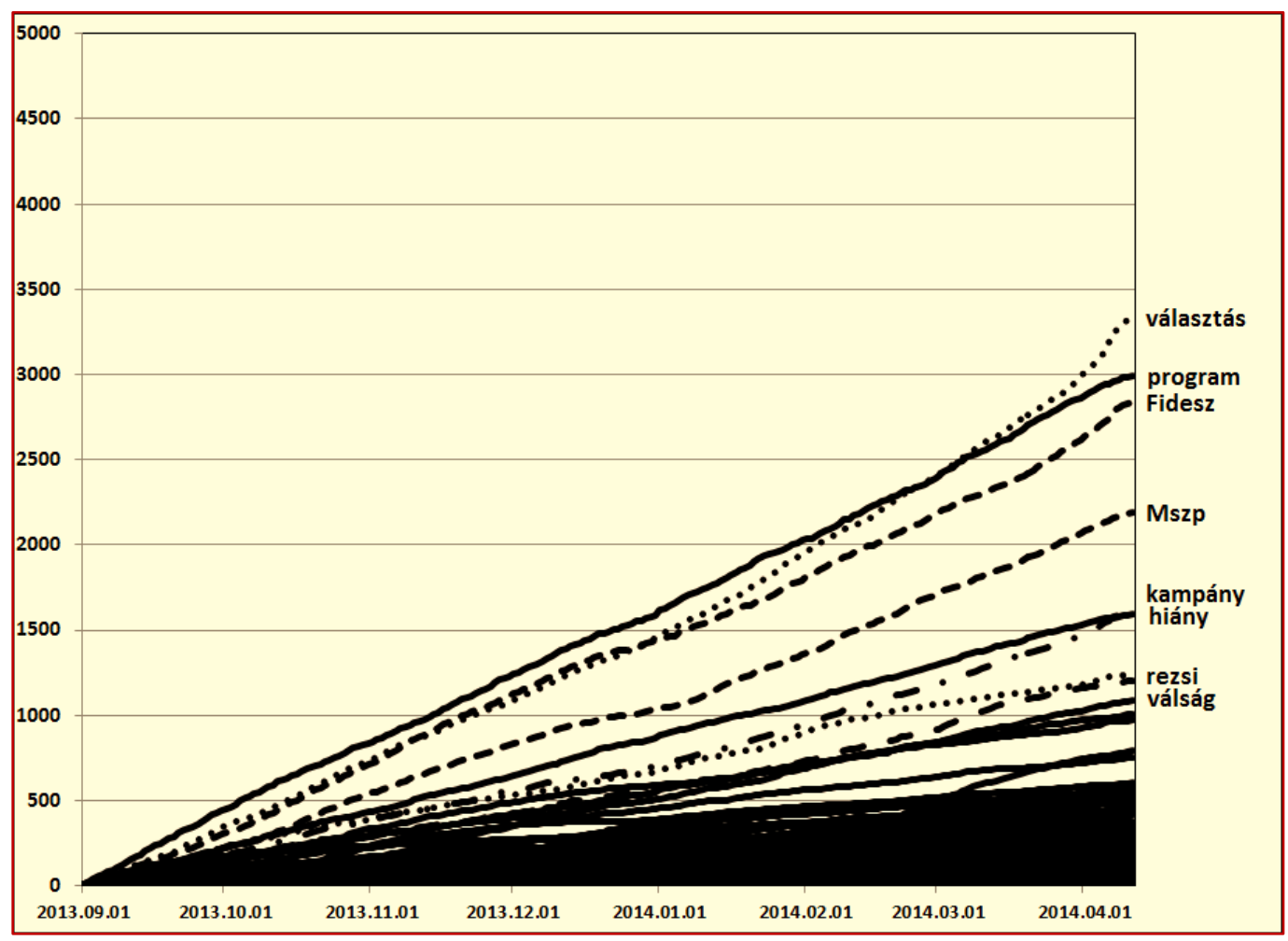


A fenti legyezőszerü forma azért is állhatott elő, mert az említési rangsor élvonalában szereplö témák kumulatív relatív-cikkszámainak idősora többségében lineáris grafikont formáz.

A kevés kivételhez tartoznak egyebek mellett az éllovas „választás”, s kisebb említés számmal a „,kampány” témák, illetve a „Fidesz” és az „,MSZP”, amelyek diagramjai a kampány végéhez közeledve - érthetö, de mégis figyelemre méltó egyöntetüséggel - valamennyi esetben enyhén gyorsuló növekedést mutatnak.

Ezen témák dinamikájának kampányvégi felgyorsulása sem teszi érvénytelenné azonban a lineáris grafikonok dominanciáját. Márpedig ez azt jelenti, hogy a kumulatív relatív-cikkszám - a továbbiakban egyszerüen kumulatív említésszám - szerinti legnagyobb említésszámú kampánytémák között többségben vannak azok, a más szempontból döntően gyüjtőfogalomként múködő témák, amelyek a kampányidőszak egészében lényegében azonos intenzitással vannak jelen. Megjelenésük nem köthető valamilyen meghatározott apropóhoz, a velük kapcsolatos hírek megjelenése az adott időszakban szinte rutinszerü, a továbbiakban ezért állandósult jelenlétü rituális témáknak fogjuk nevezni őket.

A lineáris grafikonnal ábrázolható állandósult jelenlétü rituális témák azonban az eddig vizsgált 3000 feletti kumulatív említésszámú témák világánál jóval lejjebb az ezres említésszám alatti témák között is előfordulhatnak. (4a-b. ábra) A 2010-es kampányban mindkét újságban állandósult jelleggel van jelen a „,korrupció”, ,gazdasági válság”, „,civil”, „hazugság”, ,pénzügyi válság” téma. Igaz a „roma” és ,szélsőjobb” témák ezen az említés szinten és állandósult intenzitással csak a NOL-on, míg az „IMF” és ,foglalkoztatás” témák csupán az MNO-on jelennek meg.

\section{4(a-b). ábra}

4a) 2010 NOL: korrupció, gazdasági válság, roma, szélsőjobb, civil, hazugság, pénzügyi válság, élöitélet

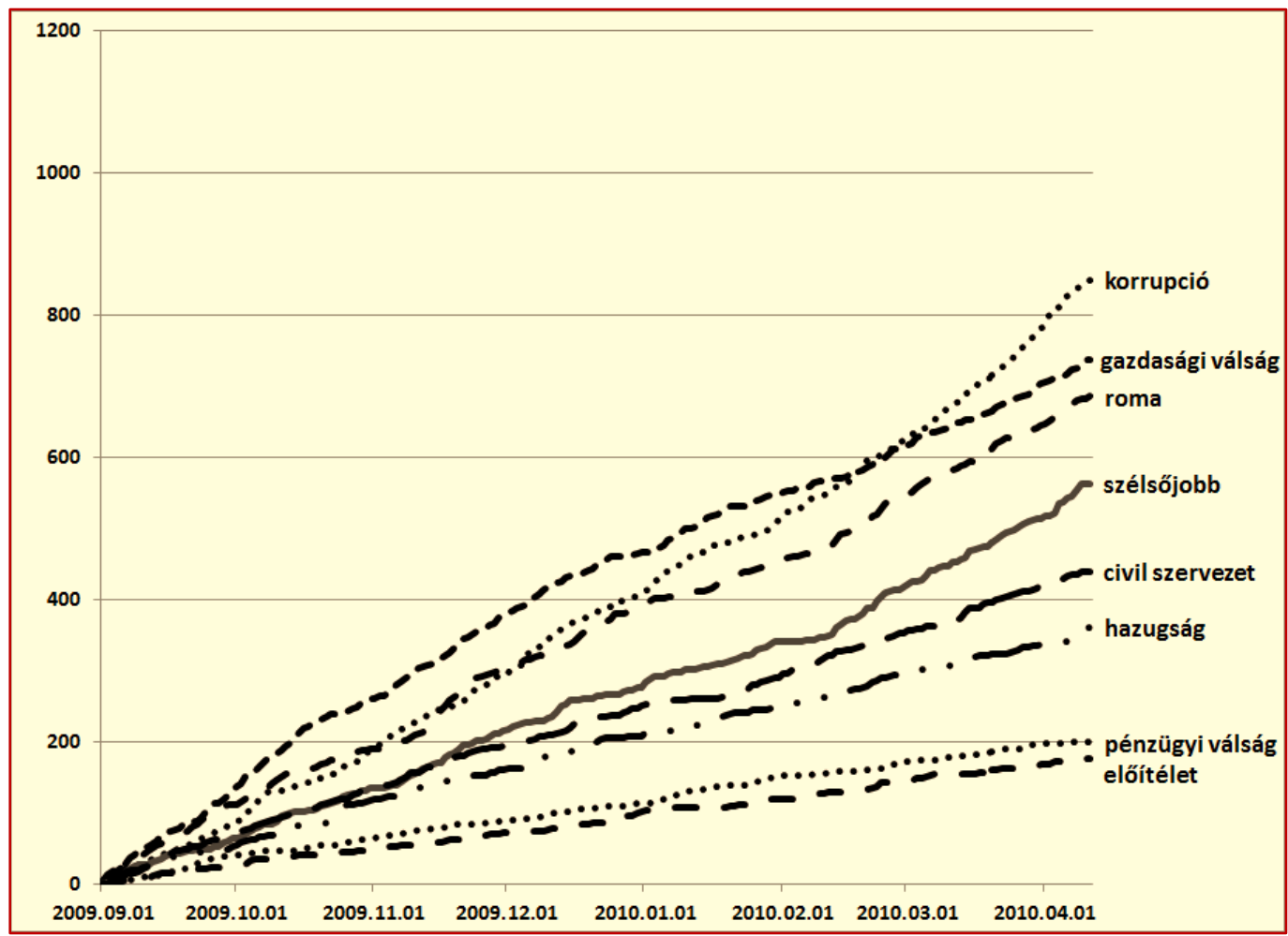


4b) 2010 MNO: civil, IMF, korrupció, gazdasági válság, foglalkoztatás, valutaalap, hazugság, felsőoktatás, pénzügyi válság

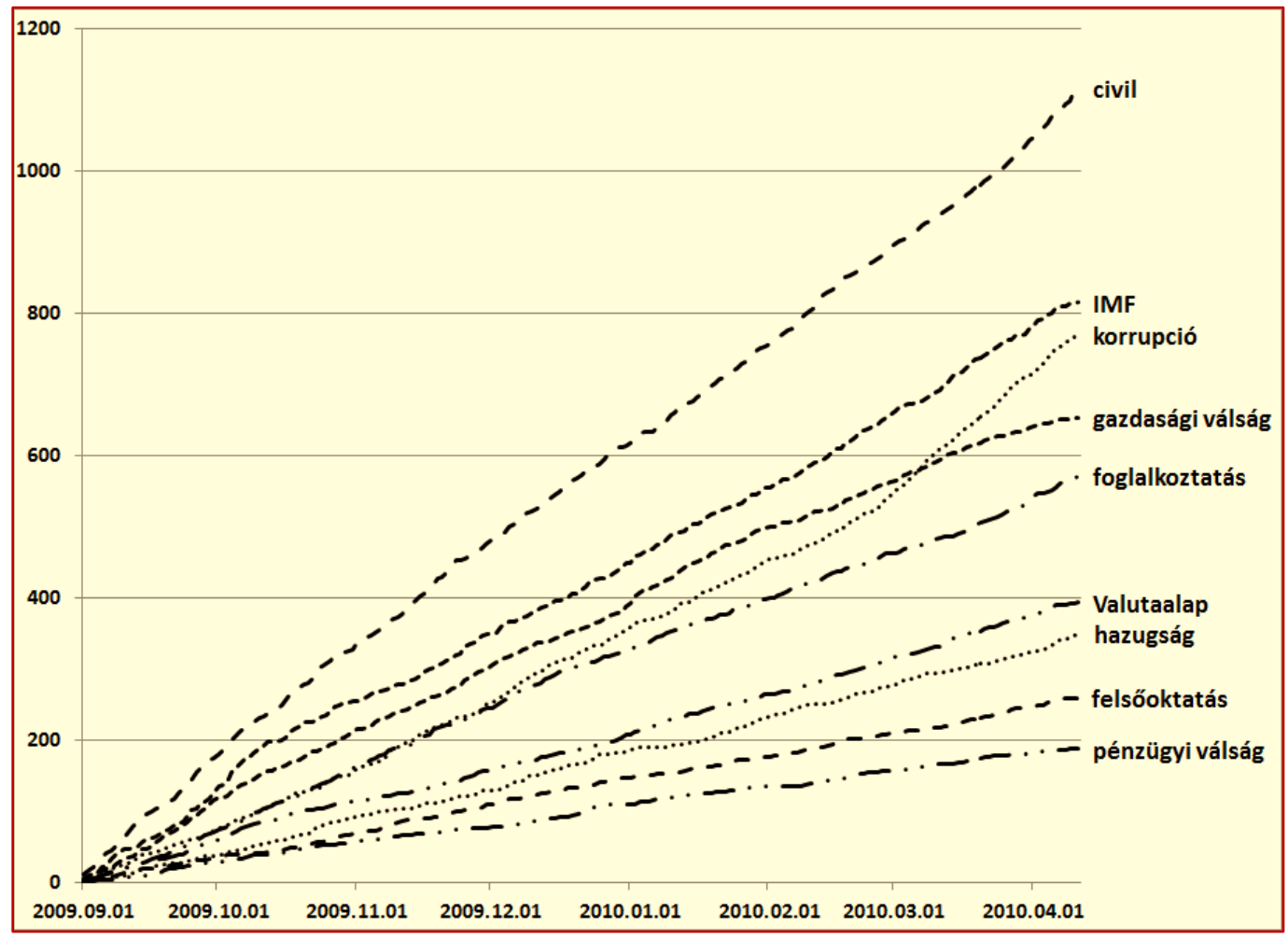

Mégis a konkrét médiumok közötti különbségnél jelentősebbnek tarjuk, hogy a szerkesztőségi szelekciók ezen a szinten nem meghatározó jelentőségüek. Sőt a médiumok közös reakciója még az olyan részletekben is megjelenik, mint például a „korrupció” témájának médiajelenléte. A kampány közeledtével e téma diagramjainak meredeksége mindkét újságban lényegében ugyanakkor kezdett el enyhén növekedni.

A 2014-es kampányidőszakban megint azt tapasztaljuk, hogy a témák terén nyoma van ugyan a szerkesztőségi preferenciáknak (5a-b. ábra), például a NOL ezen az említési szinten állandósult jelleggel a „korrupció” és ,,közmunka” témákkal, míg az MNO az „oktatás” és „reform” témákkal foglalkozik. Ezzel együtt a cikkek említésszáma terén ez a szerkesztőségi szelekció megint korlátozott hatásúnak tünik. A „rezsicsökkentés”, a „vita”, és a „Görögország” témák mindkét médiumban ugyanolyan állandósult jelenlétü rituális jelleggel vannak jelen. 
5(a-b). ábra

5a) 2014 NOL: rezsicsökkentés, vita, korrupció, közmunka, Görögország

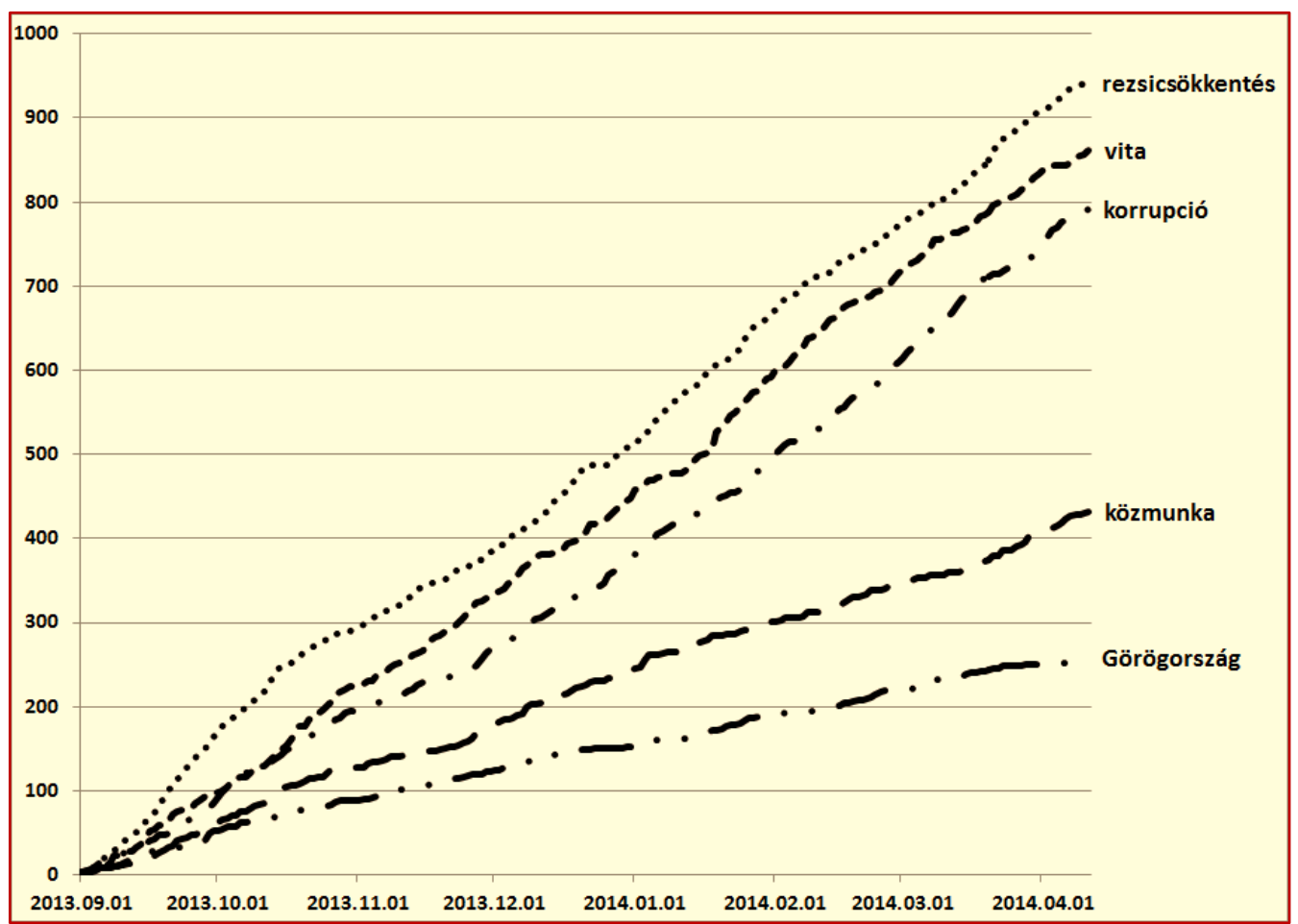

5b) 2014 MNO: rezsicsökkentés, oktatás, reform, vita, Görögország

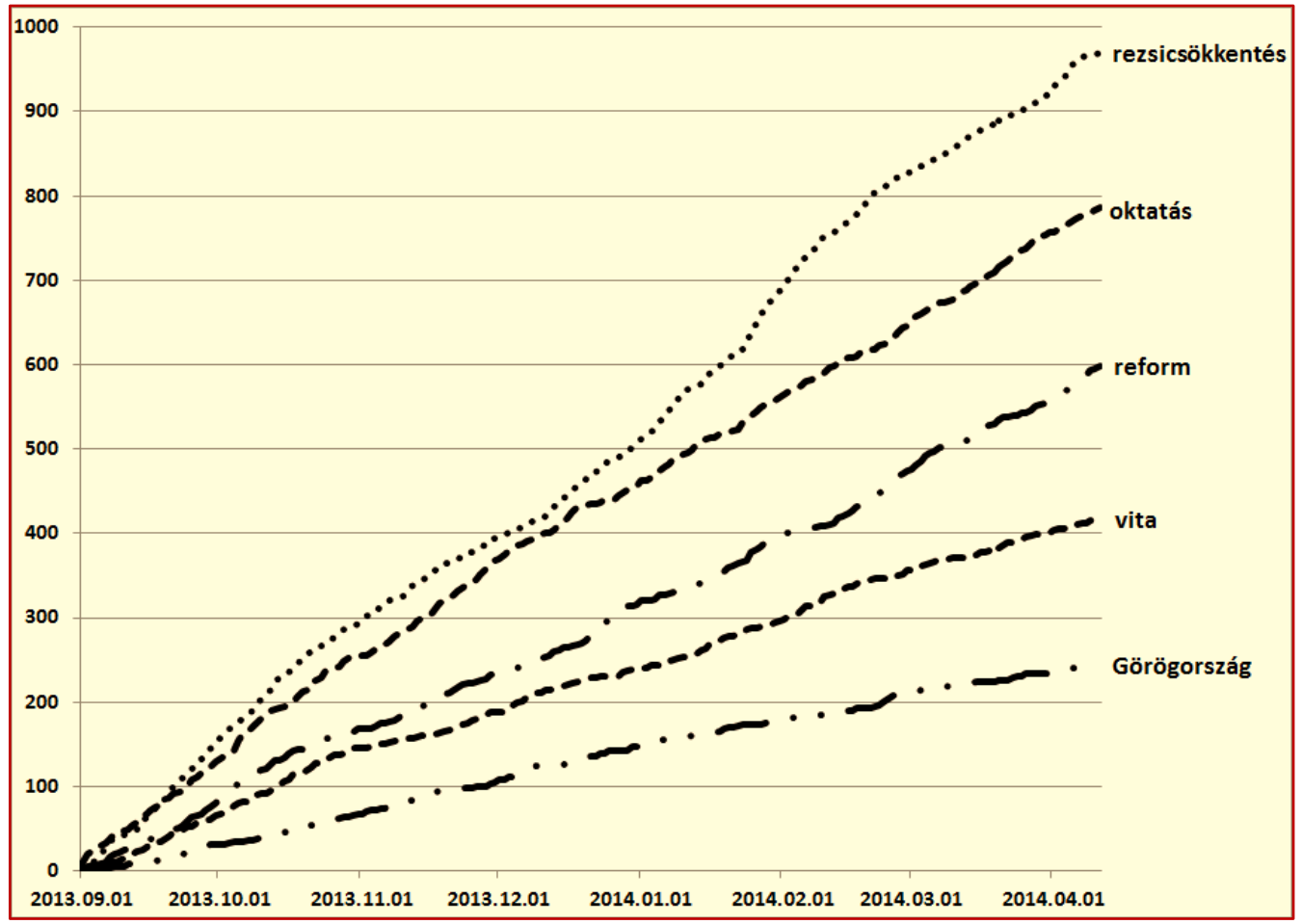

Egészen mélyen behatolva a kampánytémák említési rangsorok szerinti talapzatába, ahol a gyüjtőfogalom jellegü témák előfordulása is ritkul, a kettőszáz kumulatív említés alatti tartományban azt tapasztaljuk, hogy a 2010-es kampányidőszakban (6a-b. ábra) az „elöitélet”, 
„antiszemitizmus” és „szociális kártya” témák, a 2014-es időszakban (7a-b. ábra) pedig a „bünözés”, „,nemzeti színház”, „nyugdíjak” és „elöítélet” témák mindkét médiumban állandósult jelenlétü rituális témákként fordulnak elő.

6(a-b). ábra

6a) 2010 NOL: elöitélet, antiszemita, jövedelemadó, szociális kártya

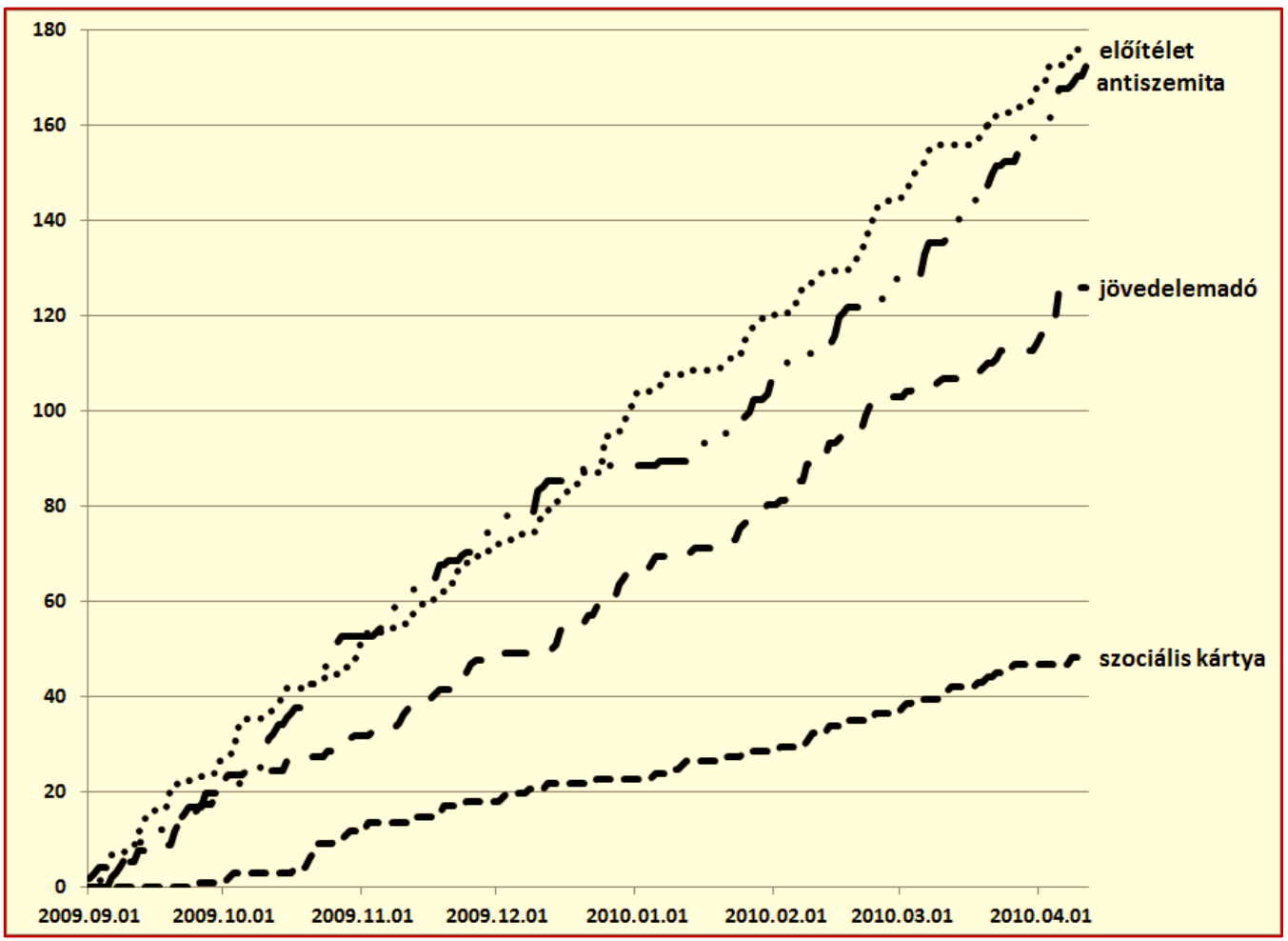

6b) 2010 MNO: hitelesség, elöitélet, antiszemitizmus, szociális kártya

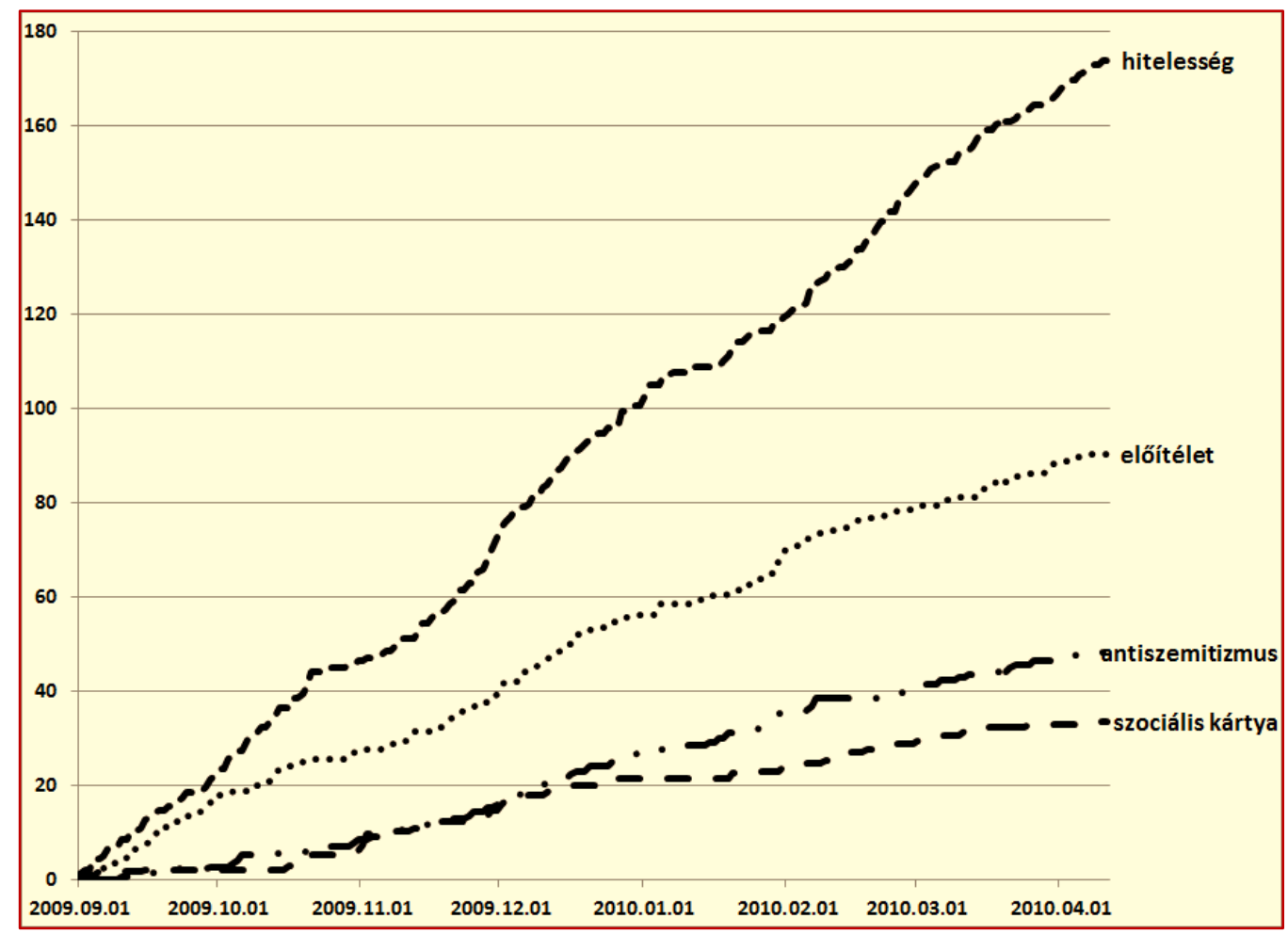


7(a-b). ábra

7a) 2014 ábra NOL: bünözés, Nemzeti Színház, nyugdíjak, elöitélet

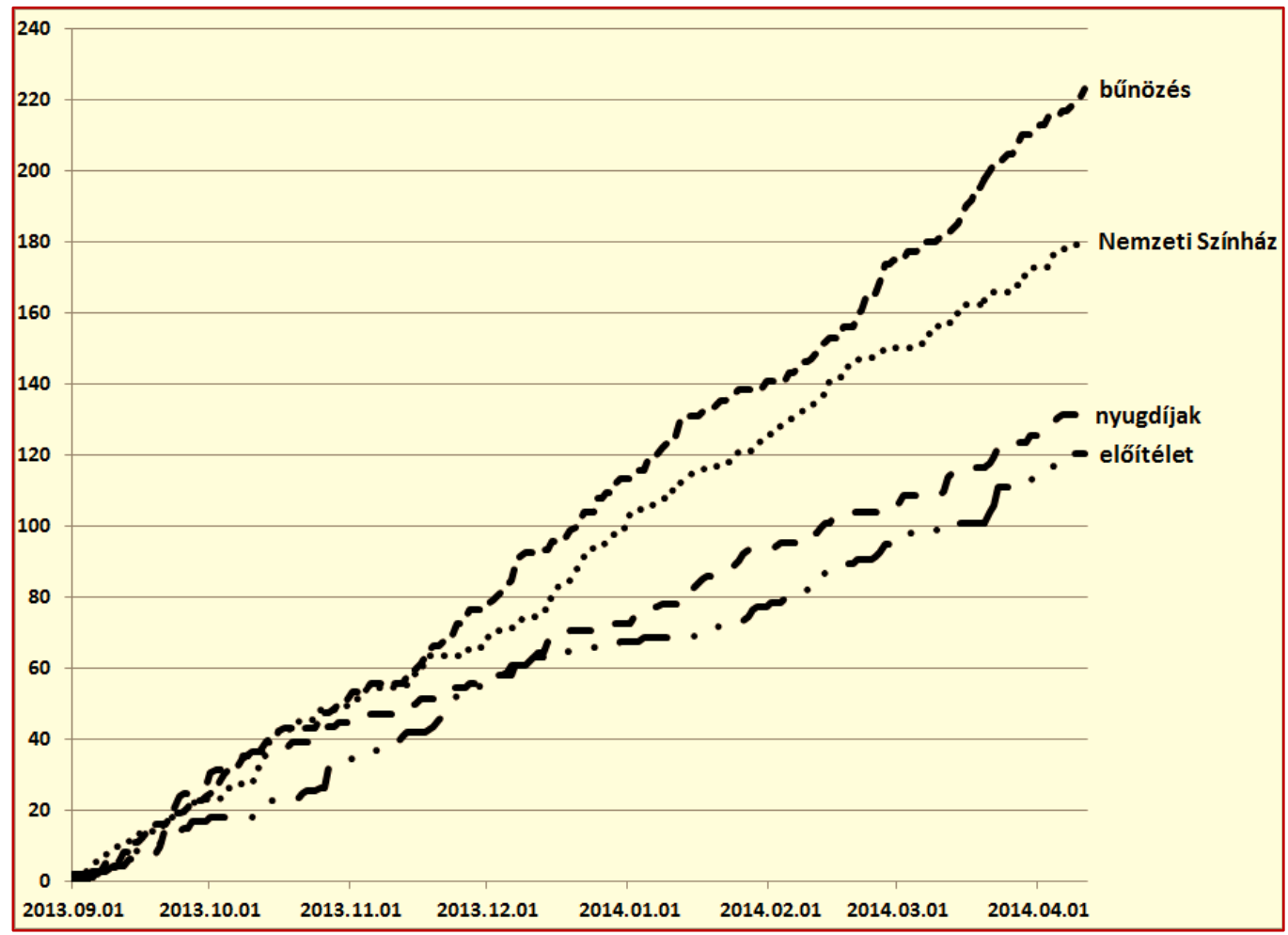

7b) 2014 MNO: fogyaték, nyugdíjak, bünözés, Nemzeti Színház, elöitélet

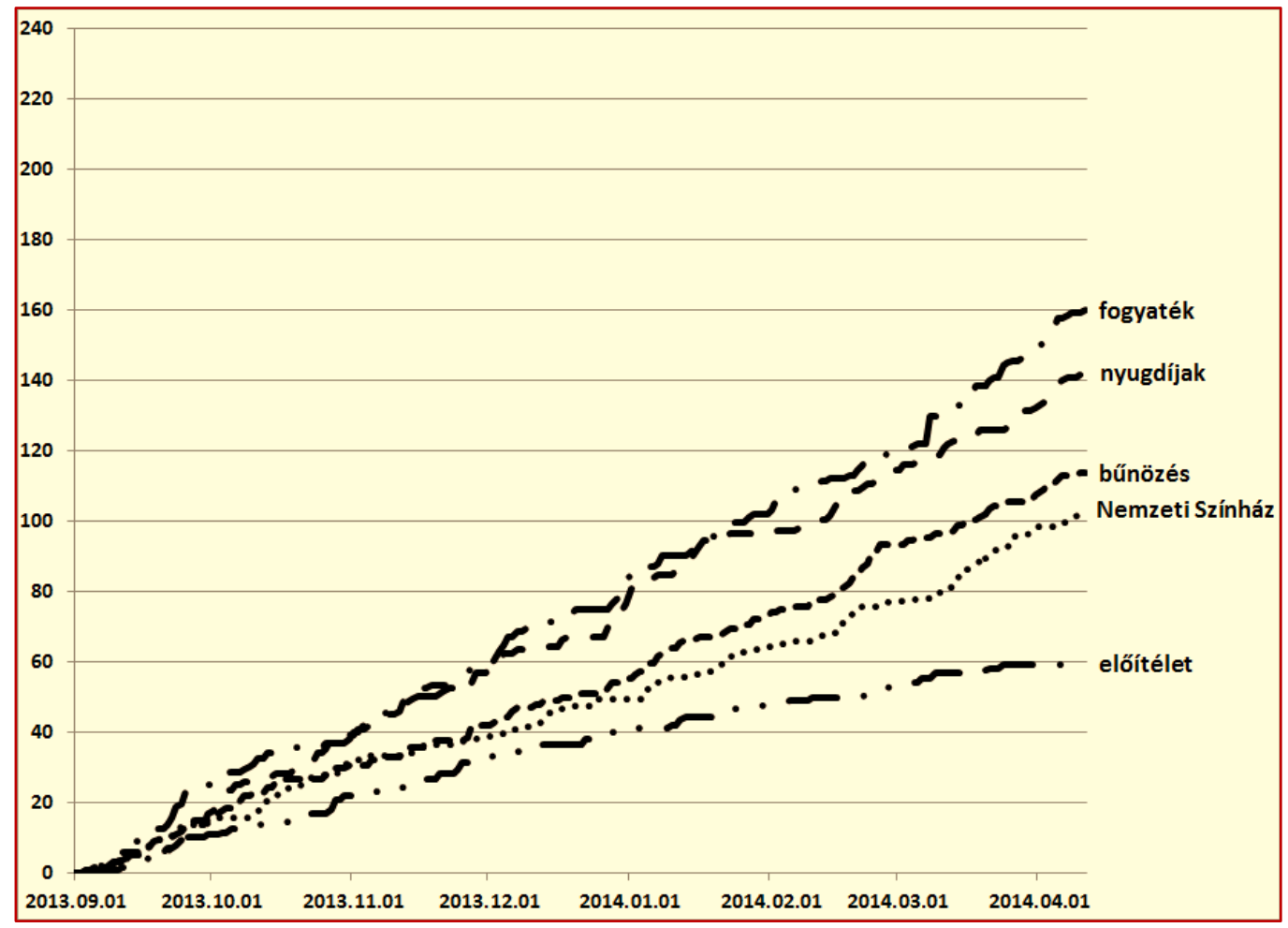


Összefoglalva tehát megállapíthatjuk, hogy a kampány teljes időszakán átívelő, lineáris kumulatív diagramokkal ábrázolható, állandósult jelenlétü témák az említési rangsorok minden szintjén előfordulhatnak. Ráadásul, ha egy téma az egyik médiumban lineáris diagramú kampánytémának bizonyult, akkor a másikban is. Még figyelemre méltóbb, hogy többségük esetében a kumulatív említésszámok szerint vett rangsorbéli helyezésükben is csekélyek az eltérések. A továbbiakban ezen állandósult jelenlétü rituális témák összességét az adott közbeszédi időszak alapstruktúrájának nevezzük.

\section{Aktualitások, újdonságok, szenzációk}

Ahhoz, hogy lineáristól látványosan eltérő dinamikára bukkanjunk, a háromezer vagy annál is több kumulatív említésszámú ${ }^{9}$ témák világából le kell süllyednünk az ezres említések alá. Figyelemre méltó, hogy a 2010-es kampányban mindkét médiumnál ugyanazzal a két témával találkozunk (8a-b. ábra). Időben elsőként a 2009 októberének második felében felbukkanó, majd a szenzáció ${ }^{10}$ alapú közbeszédi témák tipikus útját követve - a NOL-on január elejétől, míg az MNO-on jó egy hónappal később - lecsengő „HINI” témát emelhetjük ki. Emlékezhetünk még arra, hogy ez a téma a betegség újdonsága és a közvetlenül hozzákötött halálesetek miatt világszerte riadalmat keltő szenzációvá vált. Magyarországon a téma politikai jelleget is öltött. A 8a-b. ábráról jól látható, hogy ez a téma a NOL esetében dinamikai értelemben lényegében helyet cserél a 2010 februárjában látványosan felívelő pályára kerülő „Jobbik” témával.

$$
\text { 8(a-b). ábra }
$$

8a) 2010 NOL: újdonság, Jobbik, H1N1

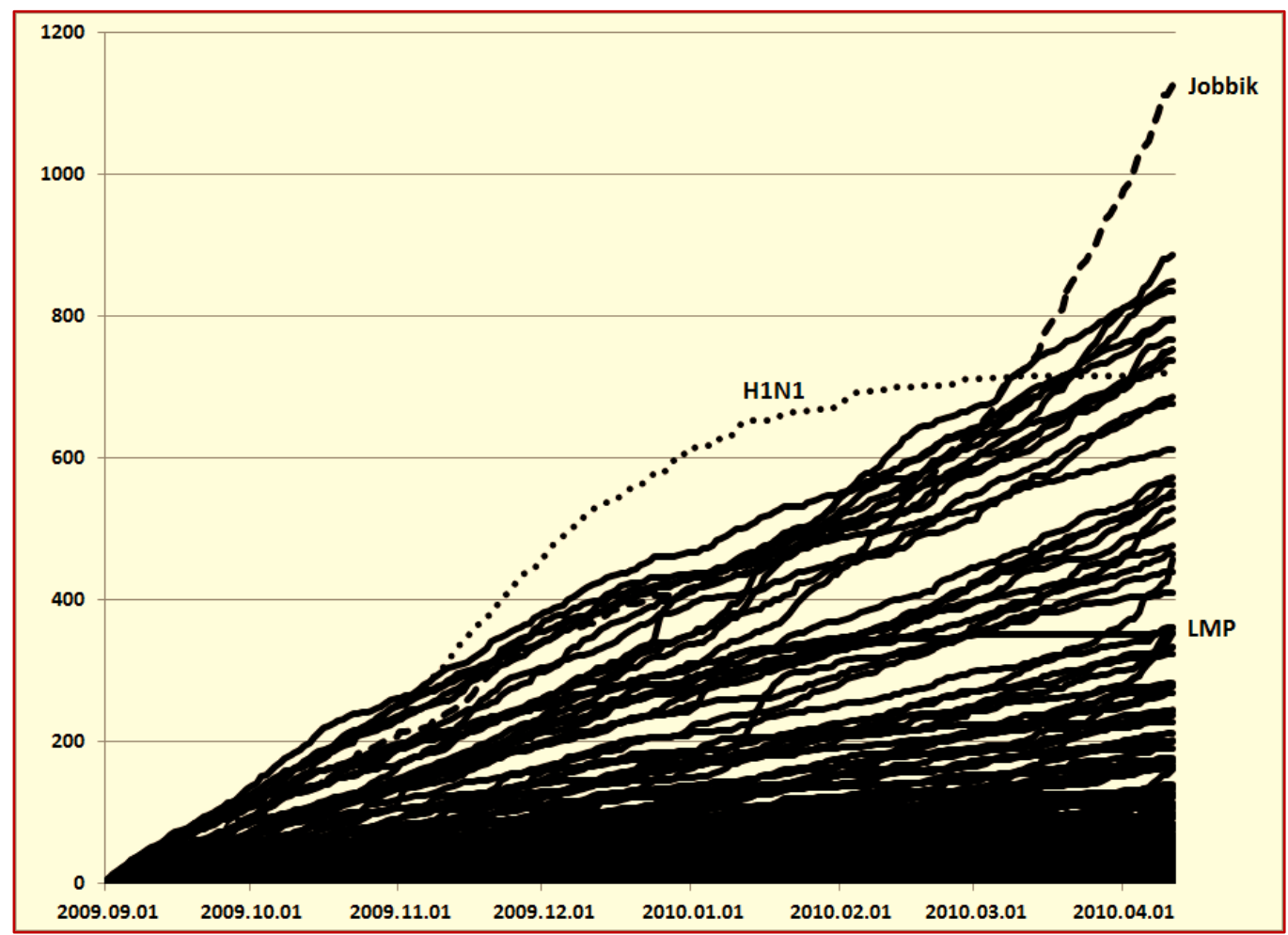

${ }^{9}$ Emlékeztetünk arra, hogy az említésszám itt teljes kampányidőszakra vonatkozó kumulatív relatívcikkszámokra utaló rövidített beszédmód.

${ }^{10}$ Lásd Fokasz 2008. 
8b) 2010 MNO: újdonság, H1N1, Jobbik

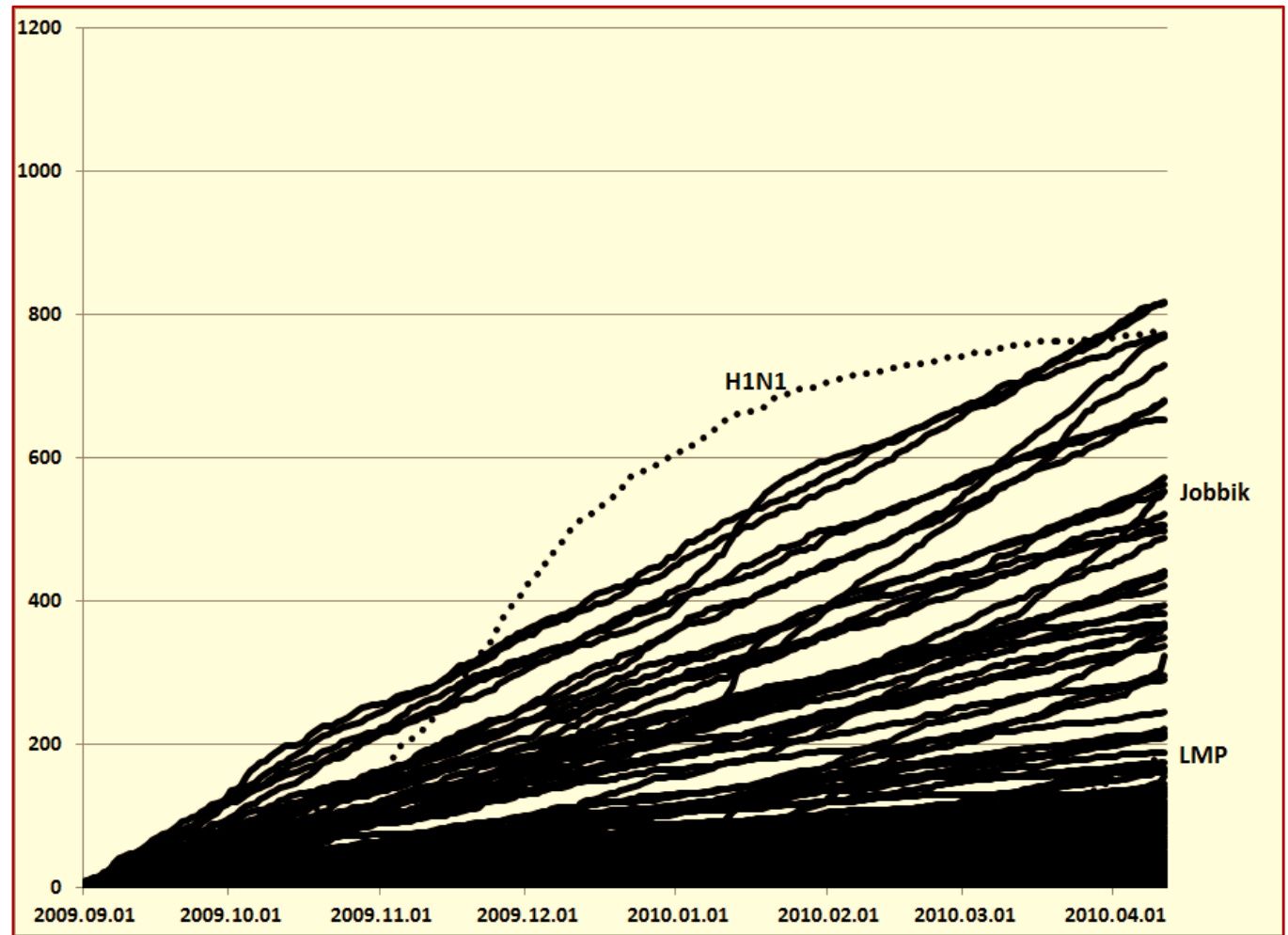

Figyelemre méltó, hogy a rendkívül hasonló növekedési forma mellett - a szerkesztőségi szelekció első látványos jeleként - a „Jobbik” kumulatív említésszáma az MNO-on csupán fele a NOL-énak. Az MNO-on a „Jobbik” témát igazából csak akkor lehet világosan detektálni, ha az állandósult jelenlétü nem nevesített rituális témáknak a 8a-b. ábra nagy részén feketéllő sürü szövevényét a 100 említésszám feletti tartományban alaposan tovább ritkítjuk. Így állítottuk elő a 8a-b. ábrából a 9a-b. ábrát, amelyet nagyrészt már megszabadítottunk a nem nevesített közbeszédi témáknak - lásd az ábra alján még megmaradó fekete diagramokat - a 8a-b. ábrát még domináló tengerétől. 
9(a-b). ábra

9a) 2010 NOL: Jobbik, H1N1, szakszervezet, sztrájk, influenza, LMP

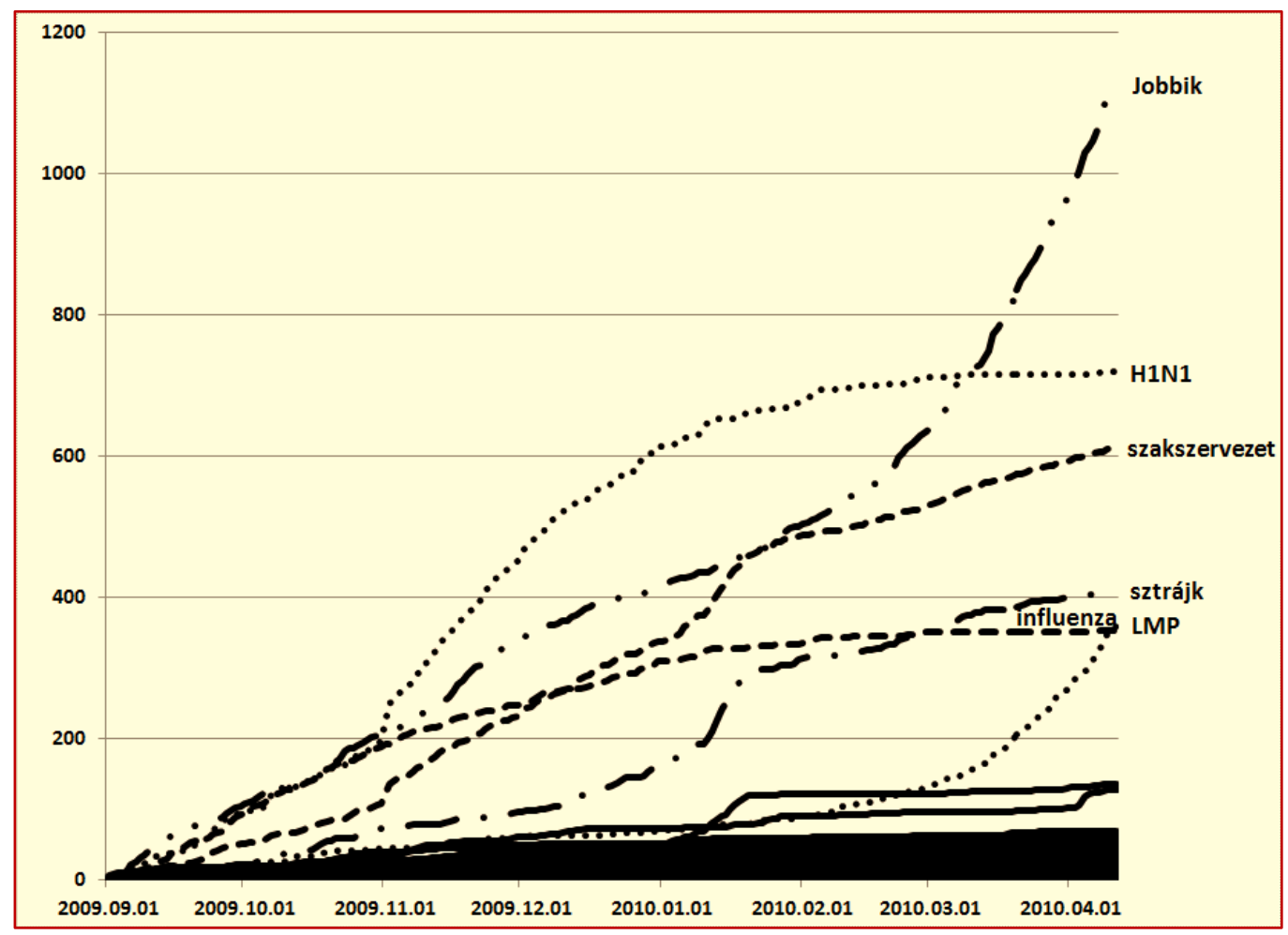

9b) 2010 MNO: H1N1, szakszervezet, Jobbik, sztrájk, LMP, kollektív szerzödés (jobboldalt)

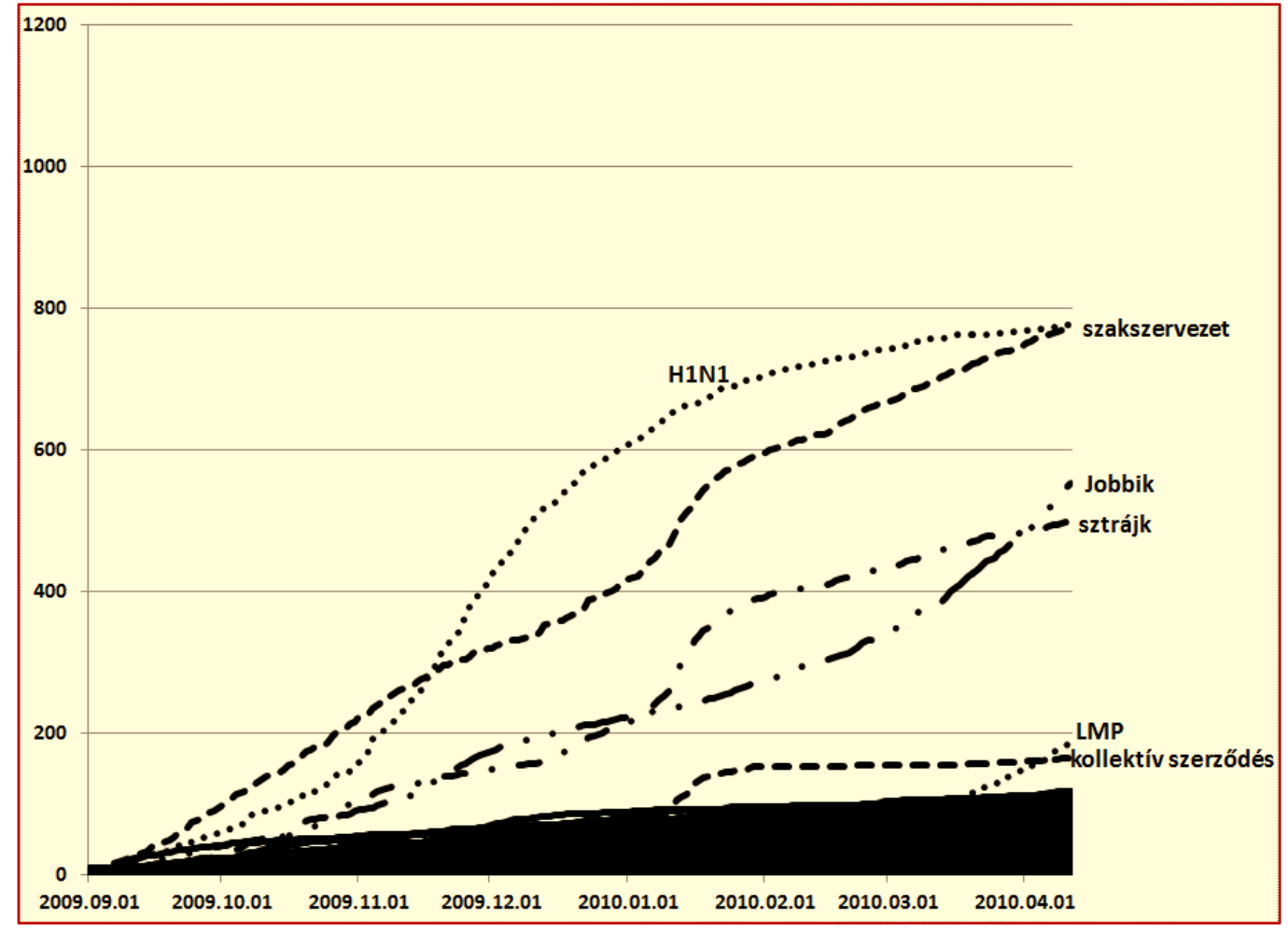


A „Jobbik”-hoz hasonló típusú dinamikát követő közbeszédi témákat - megkülönböztetve az elöre kalkulálható aktualitáshoz kötött, illetve az elözmény nélküli, váratlan szenzáció alapú témáktól - a továbbiakban újdonság alapúaknak nevezzük. A Jobbik esetében a szóhasználatot az indokolja, hogy bár a párt korábban alakult, parlamenti választási kampánybeli jelenlétét a média, ha szenzációként nem is, de kétségtelenül újdonságként kezelte. Ezt az értelmezést erôsíti, hogy a 2010-es kampányidőszakban az LMP média jelenléte jóval kisebb kumulatív említésszámmal ugyan, de hasonló növekedési mintázatot követett. Figyelemre méltó, hogy a 2014-es kampányban már mindkét párt médiajelenléte az állandósult jelenlétu rituális témák mintázatát követte.

Ha most áttérünk a 2014-es kampány újdonságainak és szenzációinak elemzésére, akkor mindenekelőtt az tünik fel, hogy az állandósult jelenlétü rituális témáktól jelentősen eltérő dinamikájú kampánytémák a 2010-es kampányidőszakhoz hasonlóan ezúttal is az ezres említési szint alatt bukkannak elő (10a-b. ábra). Elsőként a szeptembertől szenzációként induló, majd állandósult jelenlétű rituálissá átalakuló „Szíria”, később a novembertől több hullámban szenzációként nekilóduló „Ukrajna” téma mutat viszonylag nagy előfordulási számú és a lineáristól feltünően eltérő, sajátosan hullámzó dinamikát. A belpolitikai események terén a bajai időközi választással kapcsolatos médiareakció esik ebbe a kategóriába, s mutat az egykori „H1N1” témához meglepően hasonló szerepet.

A fenti példák alapján óvatosan felvethető annak lehetősége, hogy egy kampányban sajátos médiadinamikai funkciója lehet egy olyan sémának, amelyben egy az időszak elején megjelenő, korán beinduló, majd a kampányidőszak közepére lecsengő téma mintegy szokásszerűen átadja a dinamikai stafétabotot egy hirtelen felívelő új témának. Úgy tünik, hogy 2010-ben a „H1N1” és a „Jobbik”, 2014-ben pedig a „bajai választás”, illetve „Ukrajna” témák stafétája képviselte ezt a sajátos dinamikai mintázatot. Hangsúlyozzuk, hogy ez a „staféta” nem a témák tartalmára csupán funkcionális dinamikai szerepükre vonatkozik.

10(a-b). ábra

10a) 2014 NOL: újdonság, Ukrajna, Baja

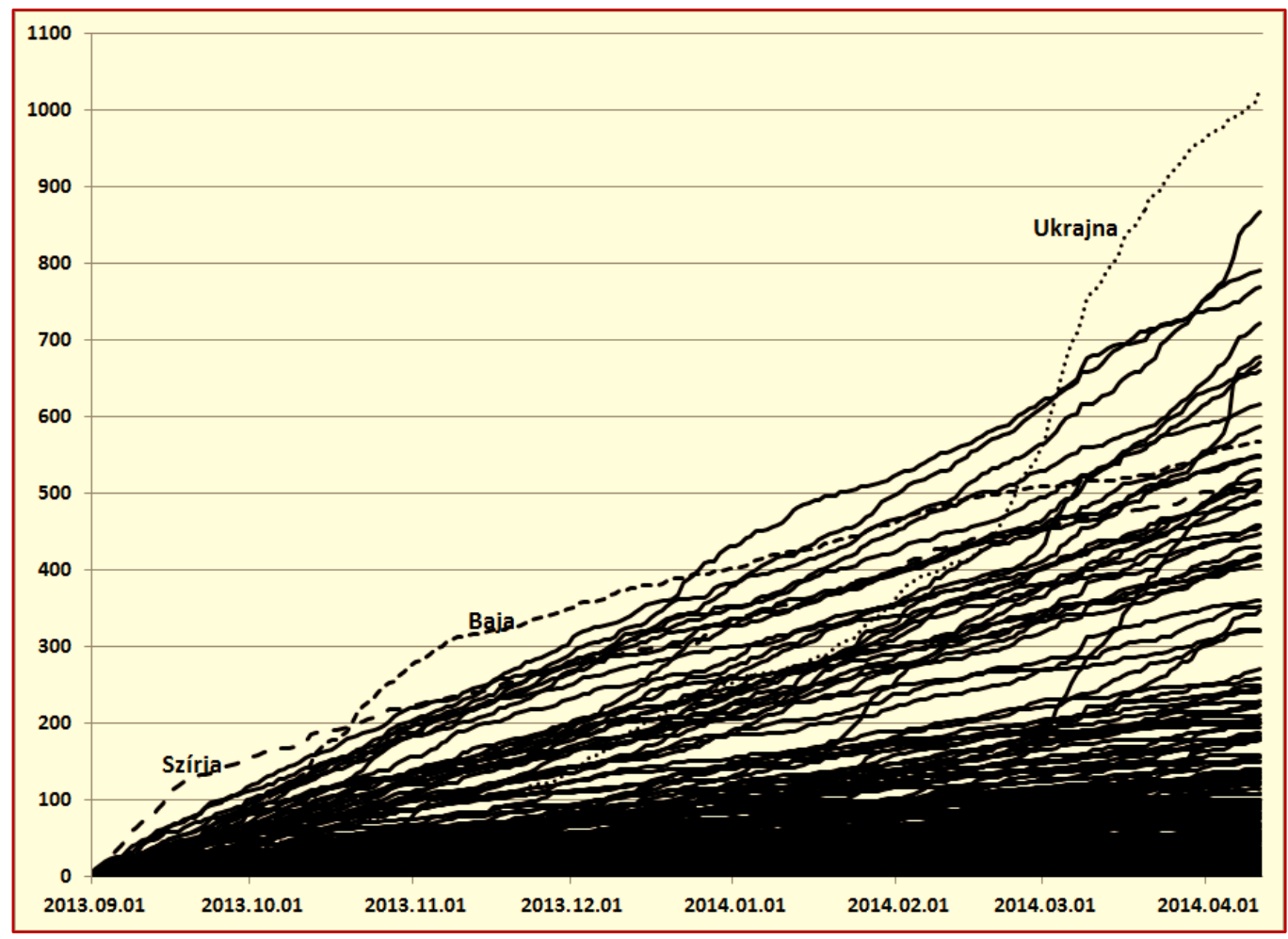


10b) 2014 MNO: újdonság, Ukrajna, Baja

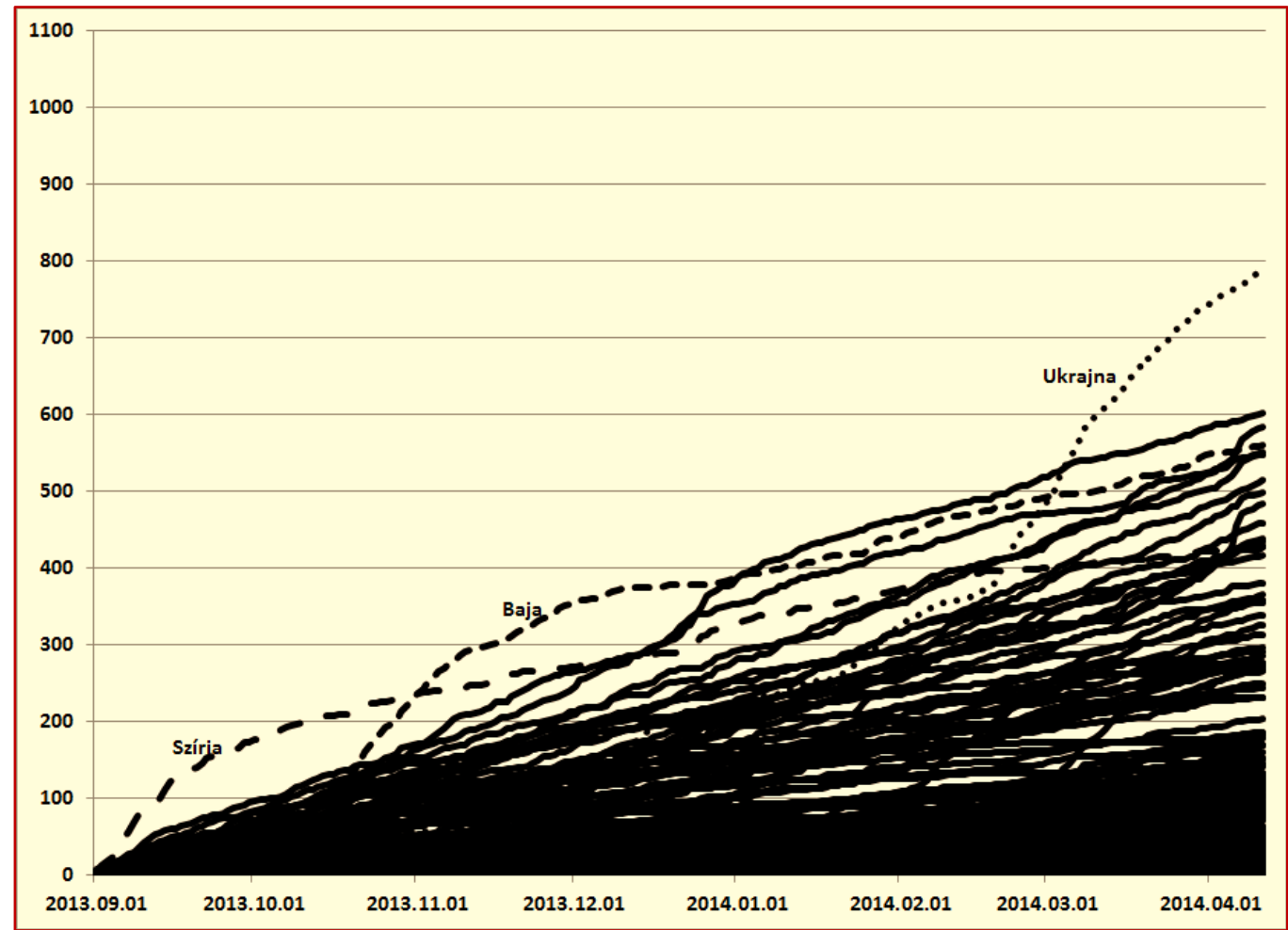

Ha az állandósult jelenlétü rituális témáknak a 10a-b. ábrán feketéllő szövevényét megritkítjuk, akkor kiderül, hogy a vizsgált újságokban az „Ukrajna”, „Putyin”, „Krím”, „Szocsi” témák egyaránt sokat szereplö, többszörösen összefonódó, szenzáció alapú témákként müködtek (11a-b. ábra a 10a-b. ábra ily módon „ritkított” változata). Az így felbukkanó közbeszédi témák újságokon belüli relatív súlya azonban eltérő volt. Különösen feltűnő, hogy az MNO a NOL-hoz képest alig több mint feleakkora teret biztosított Putyinnak. A belpolitikai témák közül ezen a szinten „Baja” egy őszi szenzációból a kampány egész időszakán átívelő állandósult jelenlétű rituális témává változott. Figyelemre méltó különbség, hogy az ezzel a témával szoros kapcsolatban lévő, de attól mégis különböző „,bajai videó” témának az MNO jóval nagyobb teret adott. Ezzel szemben a NOL-on január közepe táján erös botrányként jelenik meg a „holokauszt" téma, amely a választásokig hátralévő rövid idő alatt is 460 említésig jut, szemben az MNO-val, ahol bár szintén botrányként tálalják, 170-es említésszámmal mintegy harmad akkora teret szentelnek a kérdésnek (11a-b. ábra). 
11(a-b). ábra

11a) 2014 NOL: Ukrajna, Putyin, Baja, Szíria, Krím, Holokauszt, Simon Gábor, Szocsi

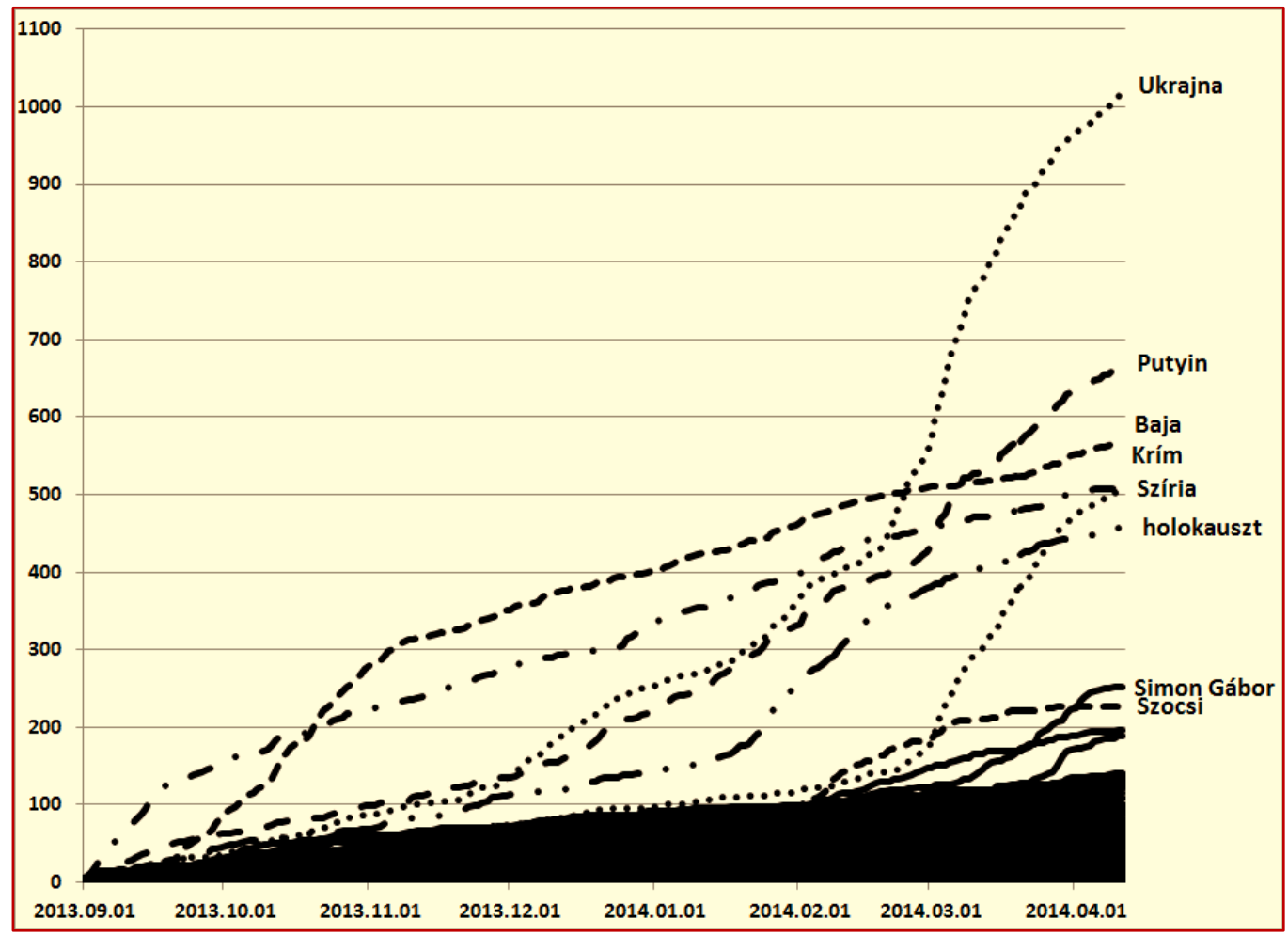

11b) 2014 MNO: Ukrajna, Baja, Szíria, Putyin, Krim, Szocsi, bajai videó

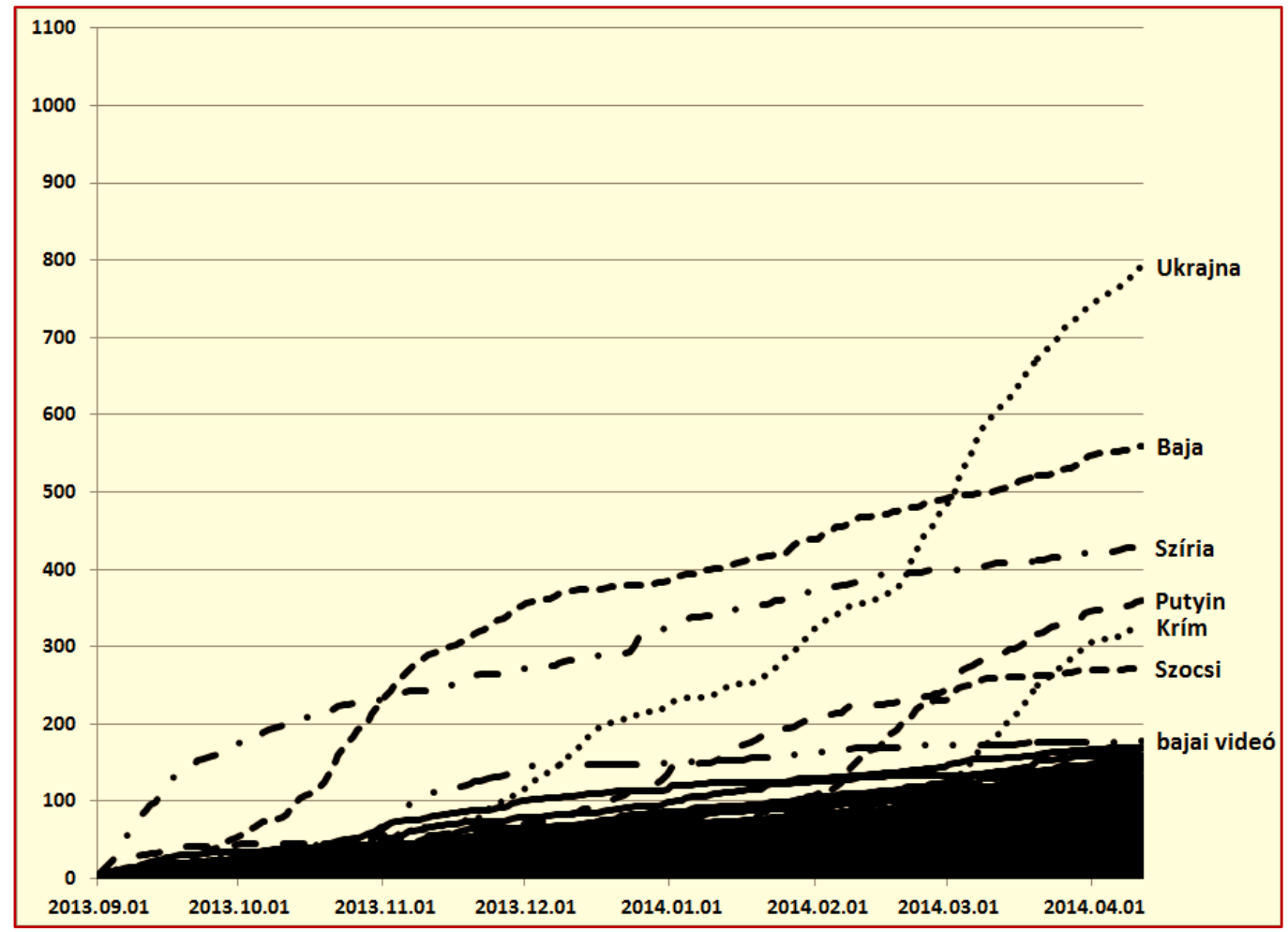


Az állandósult jelenlétủ rituális témáktól eltérően az aktualitások és újdonságok terén egyértelmủ szerkesztőségi preferenciákkal szembesülünk. Arra számítunk, hogy a szenzációk, konfliktusok, botrányok esetében ennek még világosabb jelét tapasztaljuk.

\section{Kampányfinis - szenzációk, botrányok}

Visszatérve most a 2010-es kampány idöhöz kötött változó dinamikájú témáinak elemzéséhez, a 9(a-b). ábrán egy szenzáció alapú - „H1N1" - és két újdonság alapú - „Jobbik”, "LMP”közbeszédi téma mellett a „kollektív szerzödés” egy egyszerü aktualitáshoz kötött témát képviselt. A ,szakszervezetek” és a „sztrájk” témák január elejei nekilendülése viszont mármár szenzáció számba vehető aktualitást jelzett. Ismeretes, hogy 2010 januárjában került sor a BKV történetének leghosszabb sztrájkjára. A fenti közbeszédi témák ezért átvezetnek bennünket a 2010-es kampányfinis BKV-ügyként összefoglalható botránysorozatába. Mint a 12(a-b). ábráról látszik a „BKV”, és a ,sztrájk” témák a sztrájk idején erőteljes együtt járást mutatnak. A „BKV” jellegénél fogva az egész kampányidőszakban jelenlévő aggregált témaként viselkedik. Az egyetlen sztrájk eseményt leszámítva - amely az adott pillanatban izgalmas aktualitást és növekvő intenzitású médiajelenlétet kölcsönöz a témának - tulajdonképpen állandósult jelenlétü rituális témával van dolgunk. Az igazán meglepő, hogy kisebb említésszám mellett ugyan, de ugyanez mondható el a BKV-hoz közvetlenül kapcsolódó „végkielégités” témáról is.

\section{2(a-b). ábra}

12a) 2010 NOL: BKV, sztrájk, Végkielégités, Hagyó Miklós, Antal Attila, Mesterházy Ernö, Hunvald György, Kolompár Orbán, BKV-botrány

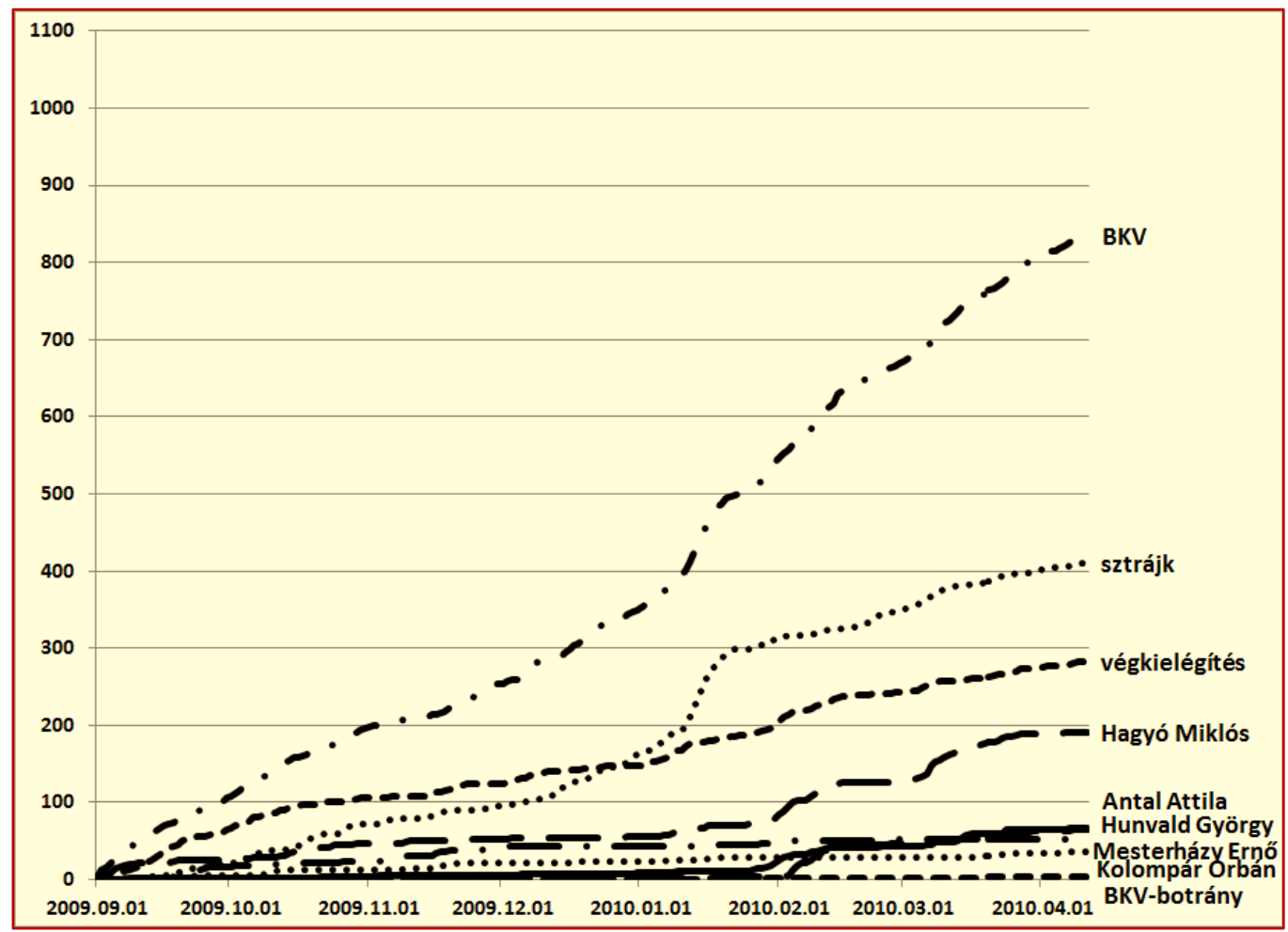


12b) 2010 MNO: BKV, sztrájk, végkielégités, Hagyó Miklós, Kolompár Orbán, Antal Attila, Hunvald György, Mesterházy Ernő, BKV-botrány (jobboldalt)

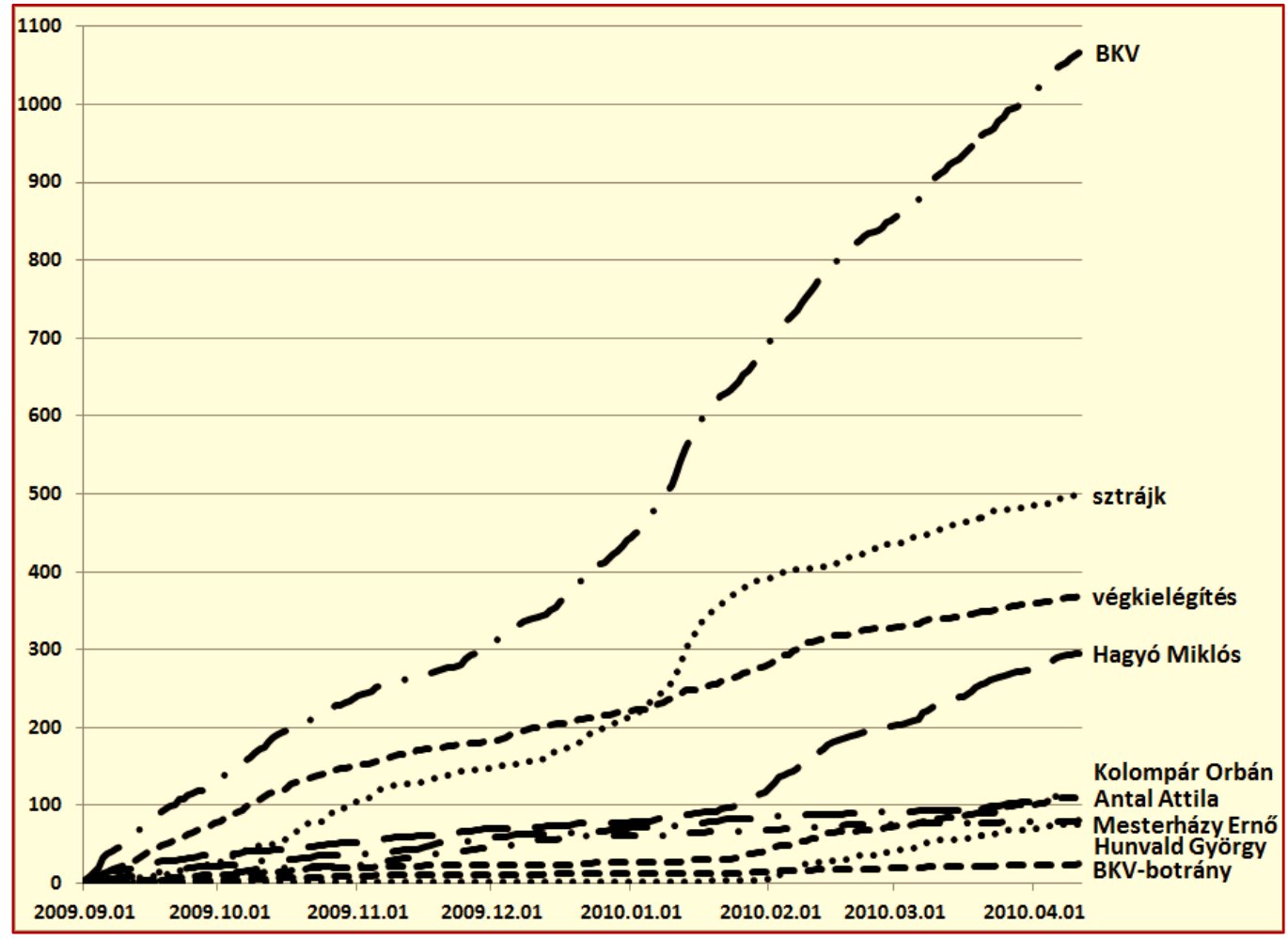

Úgy véljük, hogy folyamatos jelenlétével ez utóbbi téma teremti meg azt a szükebb értelmezési keretet, ${ }^{11} \mathrm{~s}$ szolgáltatja azt a háttértudást, amelyen belül a botránysorozat - mint a 13(a-b). ábrán látható, most már döntően személyekre fókuszáló - finomhangolását el lehetett végezni. A konkrét botránysorozatban a keretezést két büntetőügyhöz kapcsolt személy „Kolompár Orbán” és „Hunvald” lényegében állandósult jelenlétű rituális jellegü szerepeltetése tette teljessé. Ez a keretezési technika kétségtelenül hozzájárult ahhoz, hogy a 2010-es kampány idején ez a botránysorozat vált a kampányfinis meghatározó elemévé.

Érdemes felfigyelnünk arra, hogy most először bizonyos állandósult jelenlétü rituális témák és egyes szenzációk, botrányok sajátos összjátékára bukkantunk. Ennek értelmezését azonban egy kicsit később végezzük el.

${ }^{11}$ Egy kicsit tágasabb keretben ezt a szerepet az „őszödi” beszéd és „hazugság” témák játszották, de erről majd később. 
13(a-b). ábra

13a) 2010 NOL: végkielégítés, Hagyó Miklós, Antal Attila, Mesterházy Ernö, Hunvald György, Kolompár Orbán, BKV botrány

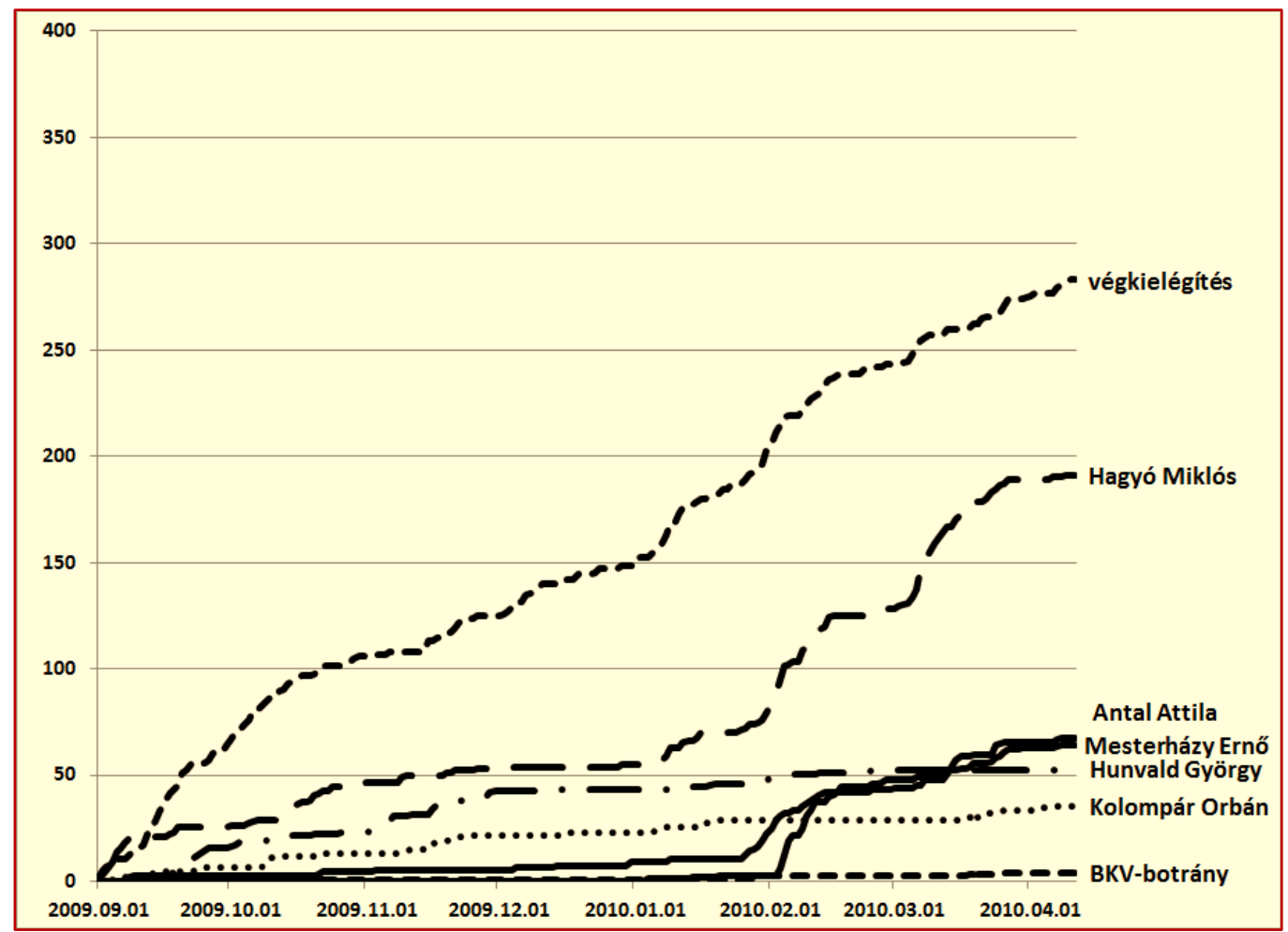

13b) 2010 MNO: végkielégítés, Hagyó Miklós, Kolompár Orbán, Antal Attila, Hunvald György, Mesterházy Ernö, BKV botrány

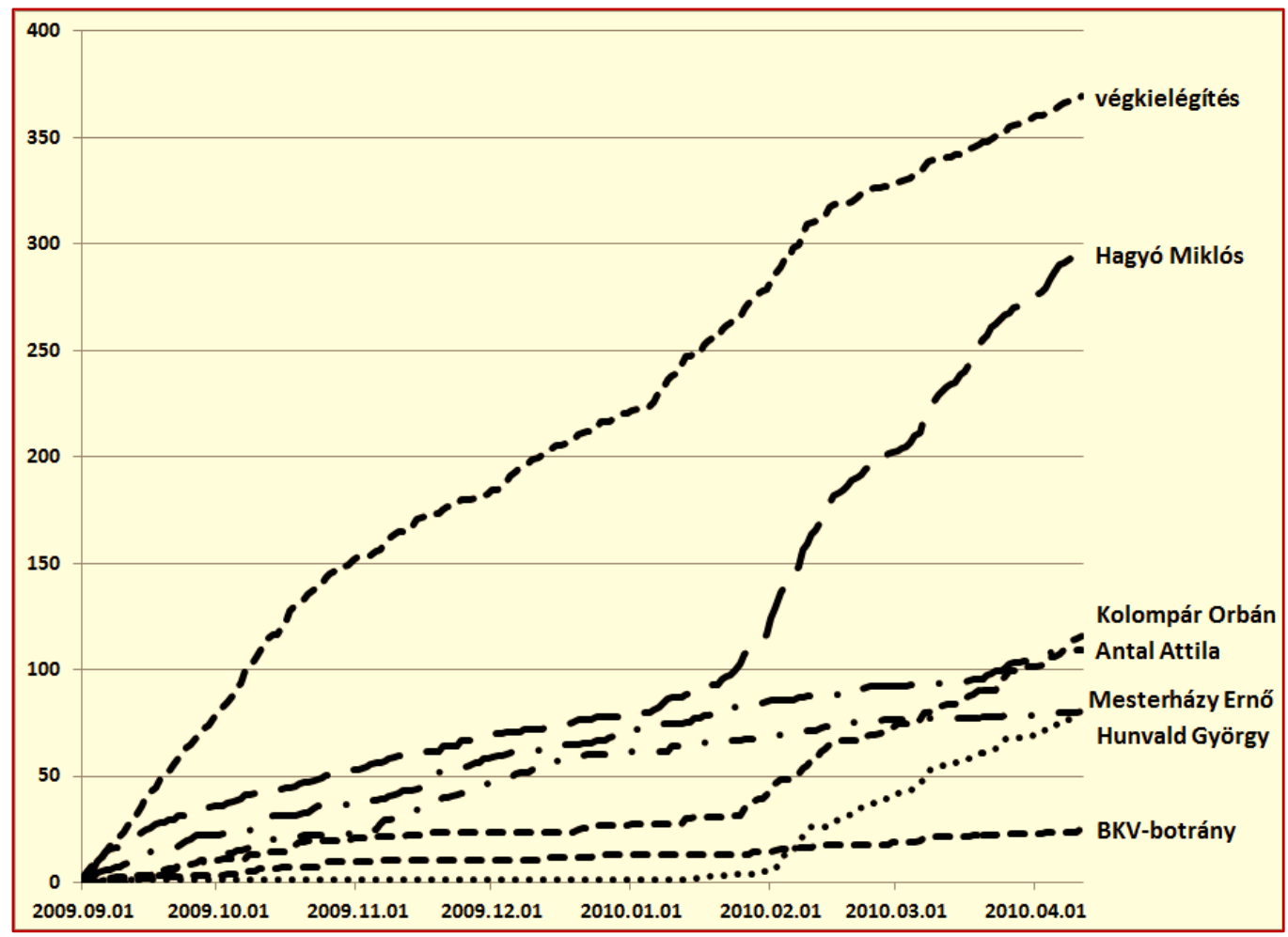


Áttérve most a 2014-es kampányfinis elemzésére, ennek meghatározó témái csak február elején törtek be a közbeszédbe (14a-b. ábra). A heves politikai viták tárgyát képező „Paks” és „vagyonnyilatkozat” hívószavú témák, bár említési sorrendjük eltérő volt, növekedési dinamikájukat tekintve lényegében mindkét médiumban hasonló szerephez jutottak. Meggyőződésünk azonban, hogy a választási célegyenesre való ráfordulás tematikai finomhangolásában a „Simon Gábor” ügy és kapcsolódó társai az „Öszöd”, „őszödi beszéd”, és „Zuschlag” témák játszottak funkcionálisan a 2010-es BKV ügyekhez hasonló szerepet. Figyelemre méltó, hogy a személyekhez kötött közbeszédi témák itt is - akárcsak a BKV esetében 2010-ben - központi szerepet kaptak a kampányfinis tematizálásában. Nem elhanyagolható különbség azonban, hogy ezúttal nem létezik a finist az egykori „végkielégítés” témához hasonlóan, közvetlenül keretező történet.

14(a-b). ábra

14a) 2014 NOL: Simon Gábor, Paks, Öszöd, vagyonnyilatkozat, öszödi beszéd, Zuschlag János

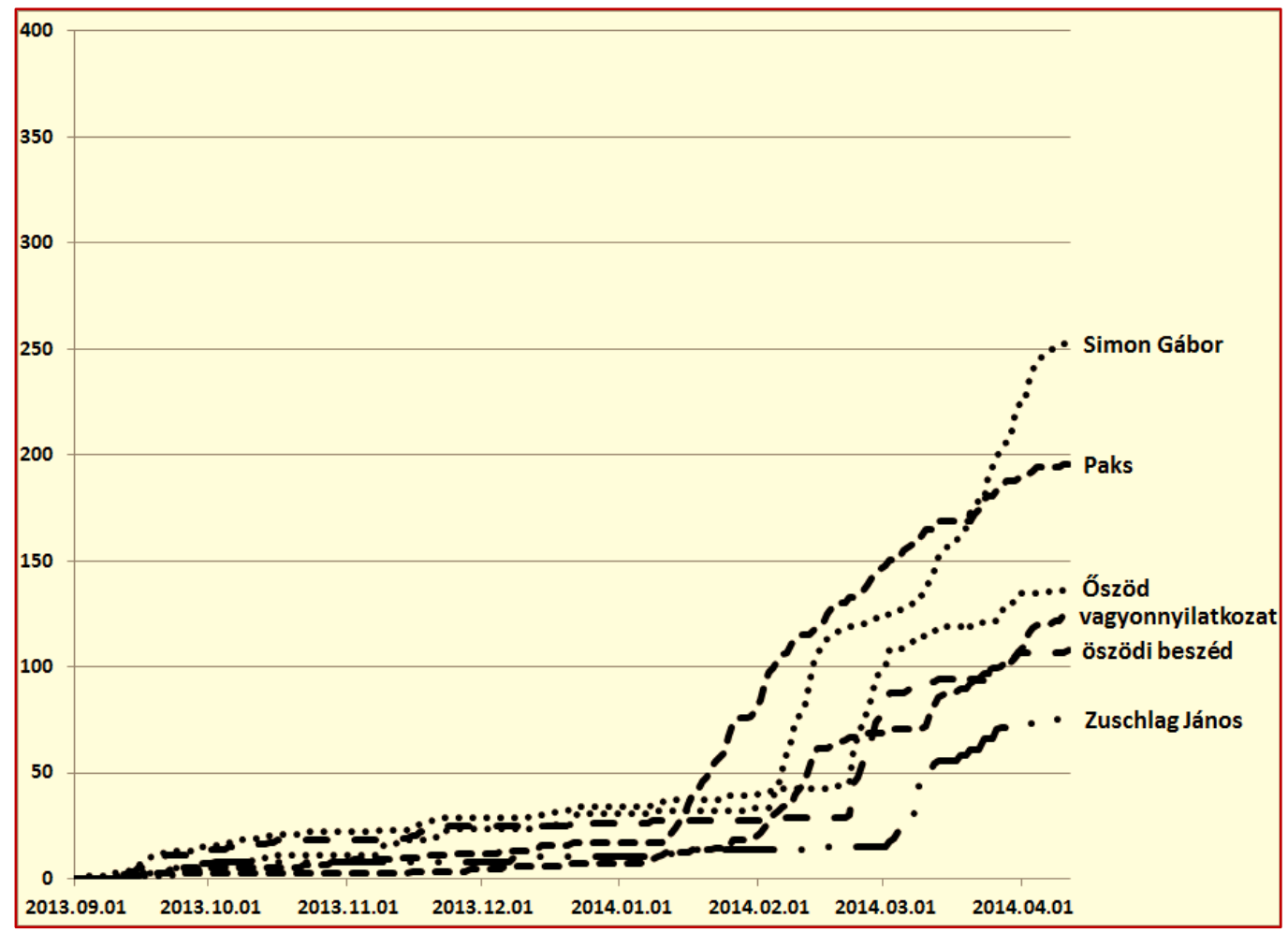


14b) 2014 MNO: Simon Gábor, ÁFA, Öszöd, bajai videó, holokauszt, vagyonnyilatkozat, öszödi beszéd, Paks, békemenet

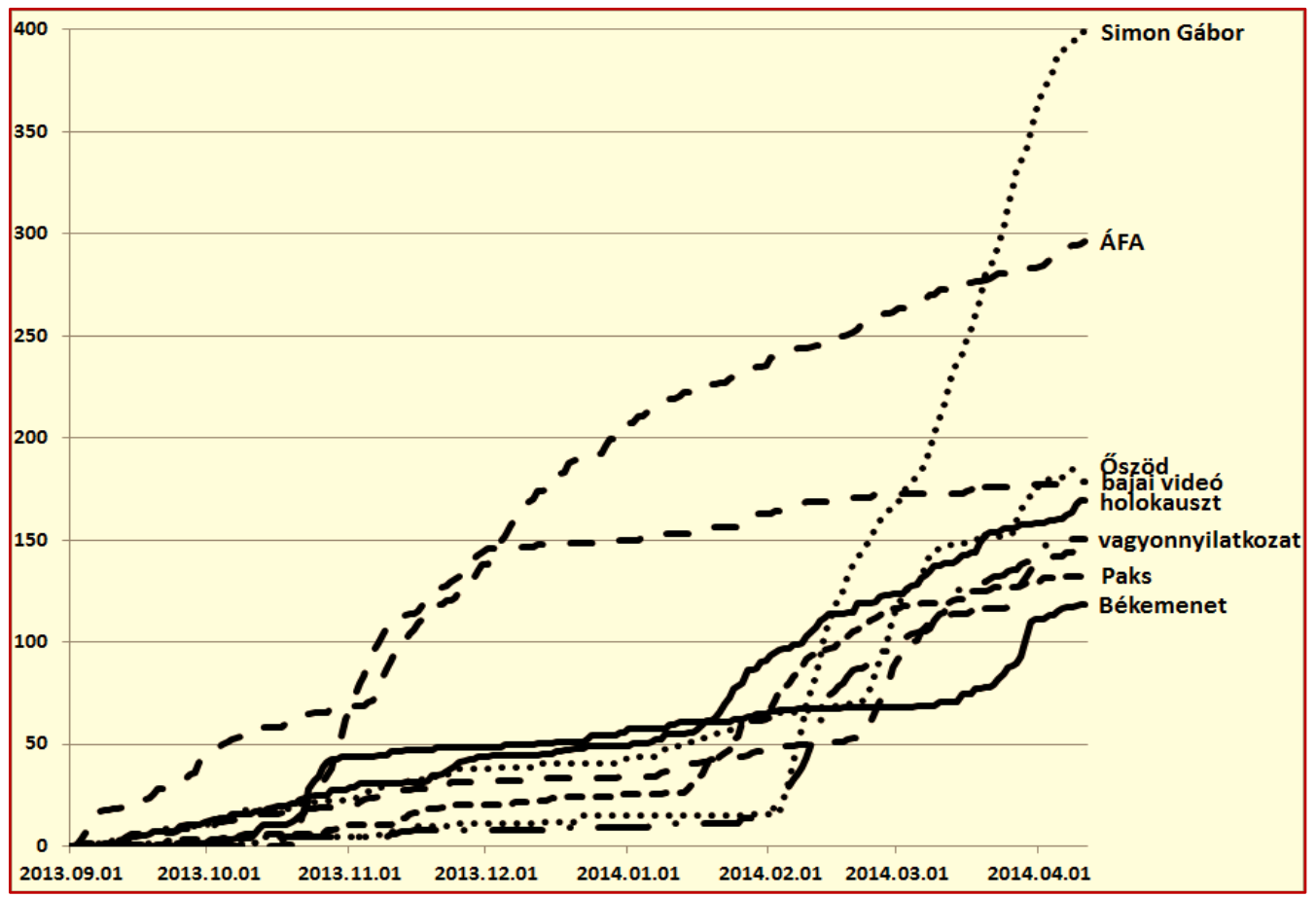

Hipotézisünk, hogy a 2014-es kampányidőszakban egy a „végkielégítés” témánál tágasabb keret, a „rezsicsökkentés” játszotta ezt a szerepet. Ez a téma mindkét általunk vizsgált médiumban rituális egyöntetüséggel ívelte át a kampány összes aktualitáshoz, újdonsághoz, netán botrányhoz kapcsolódó belpolitikai témáját (15a-b. ábra).

\section{5(a-b). ábra}

15a) 2014 NOL: rezsicsökkentés, mint keret

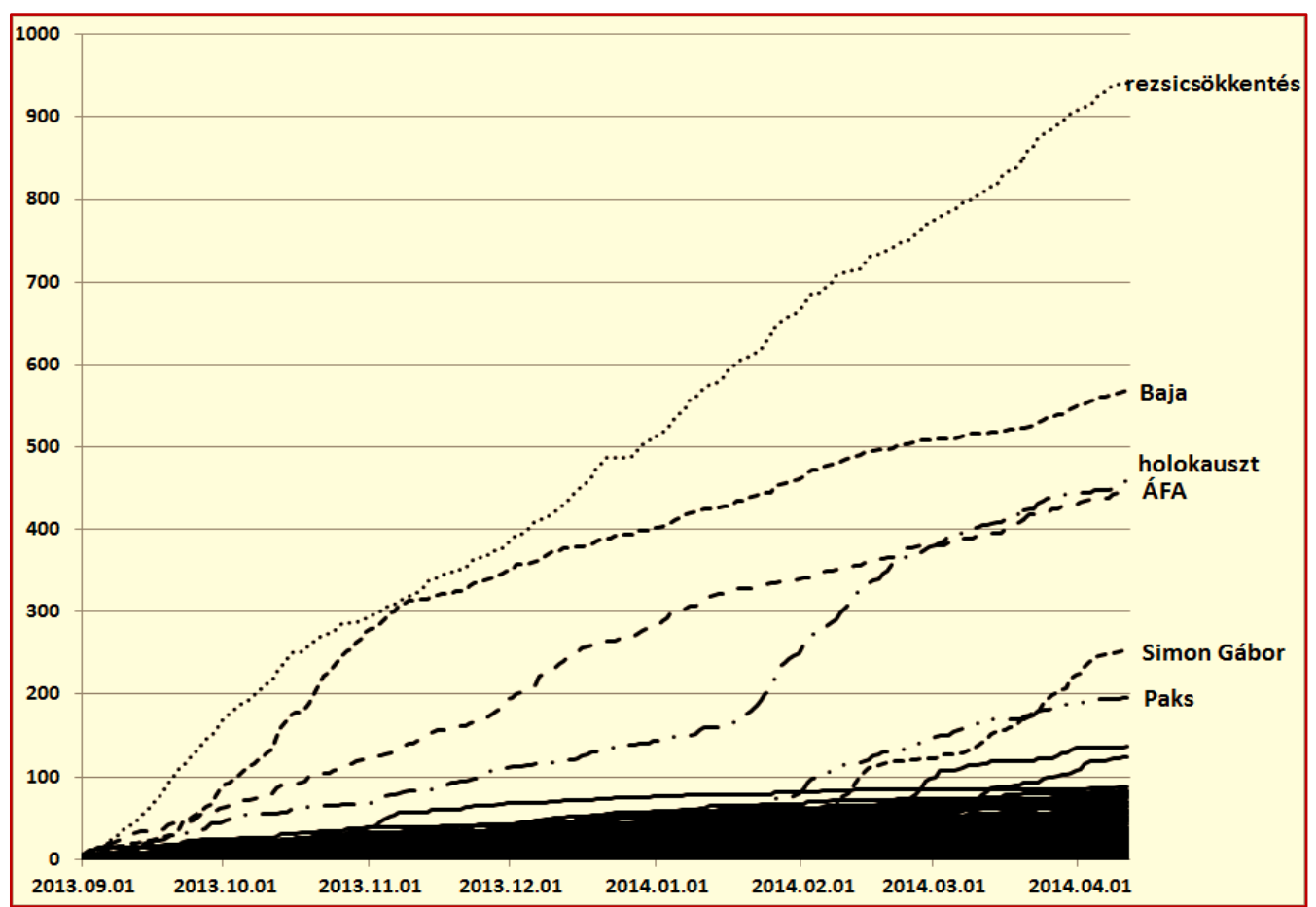


15b) 2014 MNO: rezsicsökkentés, mint keret

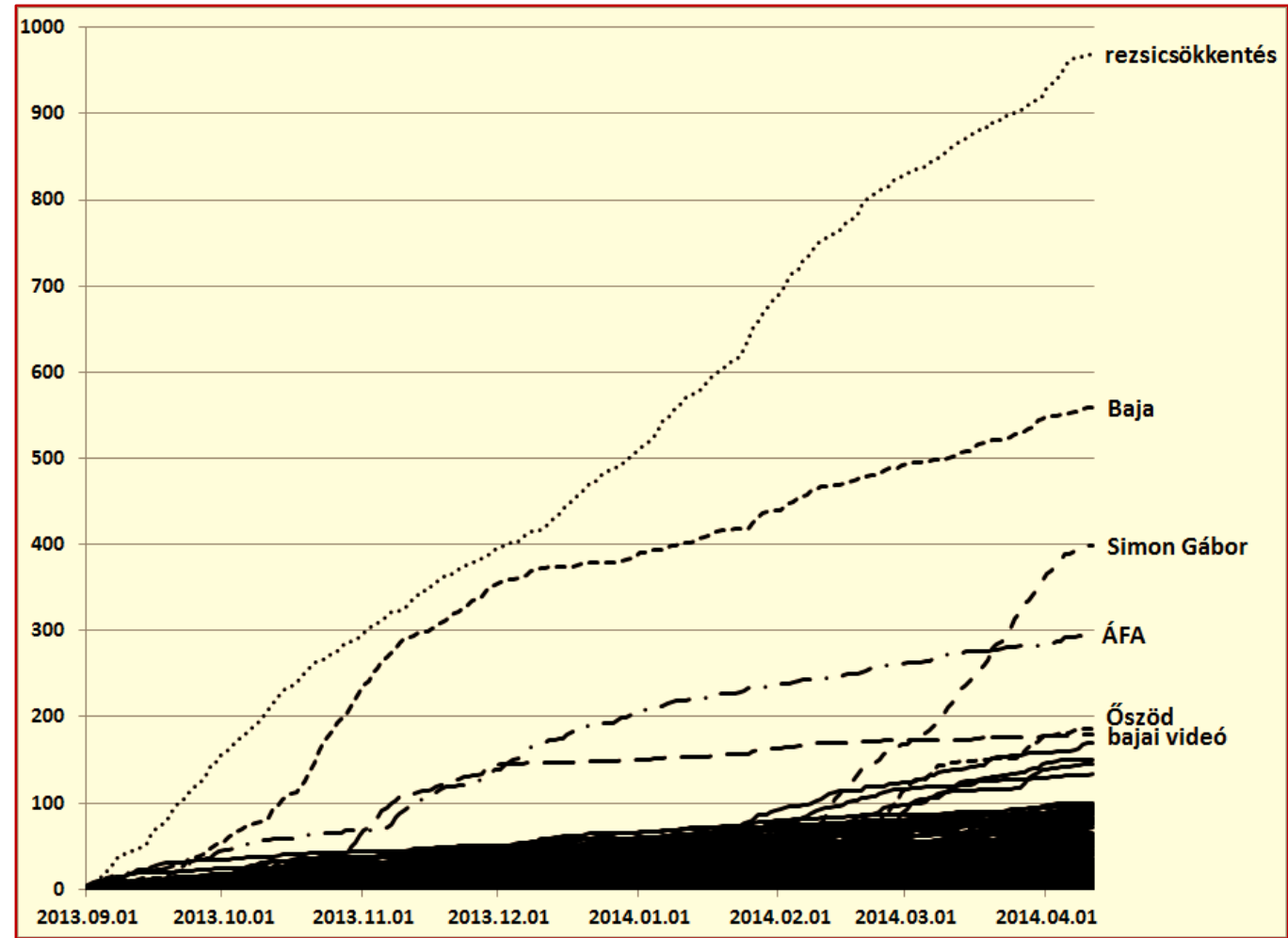

\section{Kampányfinis - örökzöldek, botrányok}

A „végkielégítés” és a „rezsicsökkentés” kapcsán ezen állandósult jelenlétü rituális témák és egyes szenzációk-botrányok sajátos összjátékára figyelhettünk fel. Az előbbiek értelmezési keretet, tulajdonképpen kontextust szolgáltatnak a botrányok botrányként történő értelmezéséhez. Az utóbbiak pedig felfrissítik, új jelentéssel dúsítják fel, s élénk színekkel ruházzák fel ezeket a továbbiakban már örökzöldeknek nevezett állandósult jelenlétü rituális témákat. Korábbi publikációnkban (Fokasz 2006) minden lineáris grafikonnal ábrázolható közbeszédi témát örökzöldnek neveztünk. Most finomítva az ott bemutatott tipológiát, az úgynevezett örökzöldeket az állandósult jelenlétü rituális témák egy speciális részhalmazaként definiáljuk.

A „végkielégités” és a „rezsicsökkentés” alapján annyit már első közelítésben is elmondhatunk, hogy az örökzöldek, mint közbeszédi témák láthatóan „túlmutatnak saját magukon”. (Fokasz-Kopper 2015) Korábbi vizsgálódásaink során a nemzetközi sajtóban a „Watergate botrány”, és a „9/11" New York-i terrortámadás, míg a hazai sajtóban az „Olaszliszka” illetve a „hazugság” témákról mutathattuk ki, hogy a közbeszéd olyan állandósult referencia pontjaivá váltak, amelyeket a „közönség különböző beállítottságú szereplői eltérően értelmeztek ugyan, de orientációs szerepük mindenki számára nyilvánvaló volt”. (Fokasz-Kopper 2015) Ezek az örökzöldek - Pierre Norával (1999) szólva - a közbeszédi térnek a közelmúlt eseményeiből alkotott, de a jelenben való orientációt elősegítő emlékezet helyeivé, lieux de mémoirejaivá lényegültek át. (Fokas-Kopper 2012)

Ezt az értelmezőkeret és orientációs jelleget az örökzöldek meghatározó jellemzőjének tekintjük. Fontos, hogy az örökzöldek dinamikai szempontból megkülönböztethetetlenek az állandósult jelenlétü rituális témáktól. Paradox módon egy döntően kvantitatív irányultságú tanulmányban arra az eredményre jutottunk, hogy az örökzöldeknek az állandósult jelenlétü rituális témától való megkülönböztetése nem kvantitatív médiadinamikai kérdés. 
Az örökzöldek a természet eseteit és a társadalom történéseit „sémába tagolják, vagy valamilyen ismert sémával kötik össze" (Luhmann 2008: 126), amely szabályozza, hogy az eseményképzés során a hírgyártók mit őriznek meg, használnak fel újra, s teszik lehetővé nem csak az ismerős, de az ,ismerősben az ismeretlen felismerését” (Luhmann 2008: 126), s ezáltal a hírfolyam továbbfolytatását.

Az örökzöldek segítségével teljesíti a tömegmédia azt a feladatát, hogy ,ismerőséget generáljon” (Luhmann 2008: 76), s egyúttal rugalmasan „,percröl percre változtassa azt, hogy az ezután következő kommunikáció résztvevői mind az elfogadás, mind az elutasítás elöidézésének kockázatát vállalhassák." (Luhmann 2008: 76)

Mint a fenti idézetekből is látható, empirikus eredményeink itt találkoznak először Niklas Luhmannak a tömegmédia valóságkonstrukciójára vonatkozó elméletével. Az örökzöldek olyan közbeszédi kategóriát képviselnek, amelyek révén a „mindenkori tárgyalt valóságmetszetekre (témák) [...] egy második, közmegegyezést nem igénylö valóság rakódik" (Luhmann 2008: 76), s amelyek segítségével a kommunikációban „bizonyos valósághipotéziseket ismertnek feltételezünk, anélkül, hogy külön be kellene vezetnünk és meg kellene indokolnunk ezeket a kommunikációban." (Luhmann 2008: 76) Az örökzöldek hozzájárulása ezért meghatározó a tömegmédiumok társadalmi funkciójához, amelyet Luhmann „nem a mindenkori aktuális információk összességében [...], hanem az ezáltal létrejött emlékezetben" (Luhmann 2008: 77) találja meg.

A luhmanni elmélet szempontjából az örökzöldek jelentősége abban áll, hogy a társadalom, mint kommunikációs rendszer stabilitásához járulnak hozzá. Luhmann ugyanis vitatja azt az évszázados elméleti hagyományt, amely szerint a társadalmi rendszer egy „explicite vagy implicite megkötött társadalmi szerződésre, [...] konszenzuálisan elfogadott közös meggyőződésre” épül. (Luhmann 2008: 126) Luhmann szerint ugyanis „,nagyon kockázatos lenne [...] konszenzusokra támaszkodni, amelyek tulajdonképpen normatív szükségletek" (Luhmann 2008: 126), s nem biztos, hogy fennállnak.

A társadalom, mint a kommunikáció rekurzív müködéséből keletkező rendszer „stabilitása (=reprodukáló képessége) elsődlegesen” a kommunikáció ezen rekurzív müködése révén elöállított „objektumok generálásán alapszik, amelyek a későbbi kommunikációban adottnak vehetők." (Luhmann 2008: 126) Mint láttuk, ezen objektumok egyikét képviselik az örökzöldek. Jelentőségüket pedig az adja, hogy „nehéz lenne elképzelni, hogy egy kommunikatív müveletekre épülö, az egyéni horizontokon messze túlmutató társadalom hogyan lenne képes müködni, ha ezt a nélkülözhetetlen feltételt nem biztosítaná maga a kommunikációs folyamat." (Luhmann 2008: 126)

Felmerül azonban a kérdés, hogy miként tehettek szert az örökzöldek ilyen tulajdonságra? A kérdés annál is fontosabb, mivel Luhmann szerint a tömegmédia rendszere, mint minden rendszer müveletileg zárt. Az elme szintjén ez egyszerüen szólva azt jelenti, hogy semmilyen idegen gondolat nem kerülhet a fejünkbe, s mi sem plántálhatjuk gondolatainkat mások elméjébe. A rendszerek „müveleti szinten nem képesek [...] elérni környezetüket.” (Luhmann 2008: 134) S minden rendszernek csak saját - a tömegmédia esetében kommunikációs - műveletei állnak rendelkezésre, ahhoz, hogy struktúráit felépítse. „Ennek ellenére bekövetkezhetnek erőteljes és ismételt ingerlések, amelyeket a rendszeren belül mindenkor információkká dolgoznak fel. Hosszabb távon nézve a strukturális fejlődés meghatározott forrásokból eredő ingerlések folyamatos áramlásával magyarázható.” (Luhmann 2008: 134)

A rendszerek strukturális fejlődésének ilyen ,pavlovi” jellegü kondicionálására szolgáltatnak példát az örökzöldek, s ennek is két eltérő jellegü alfaját képviselik a „hazugság”, illetve a „rezsicsökkentés” közbeszédi témák.

A 16. ábra a társadalmi rendszer három egymással részben átfedő alrendszere - a politika, a média, és a politikai közösség - közti viszony sematikus ábrázolásával szemlélteti ezt a 
folyamatot. Felhívjuk a figyelmet arra, hogy szóhasználatunkban a „Rezsicsökkentés” valamint „Öszöd-hazugság” közbeszédi témákat megkülönböztetjük a rezsicsökkentés és az Őszödhazugság névvel jelölt politikai történésektől.

16. ábra

Örökzöldek két eltérö kialakulási mechanizmusa

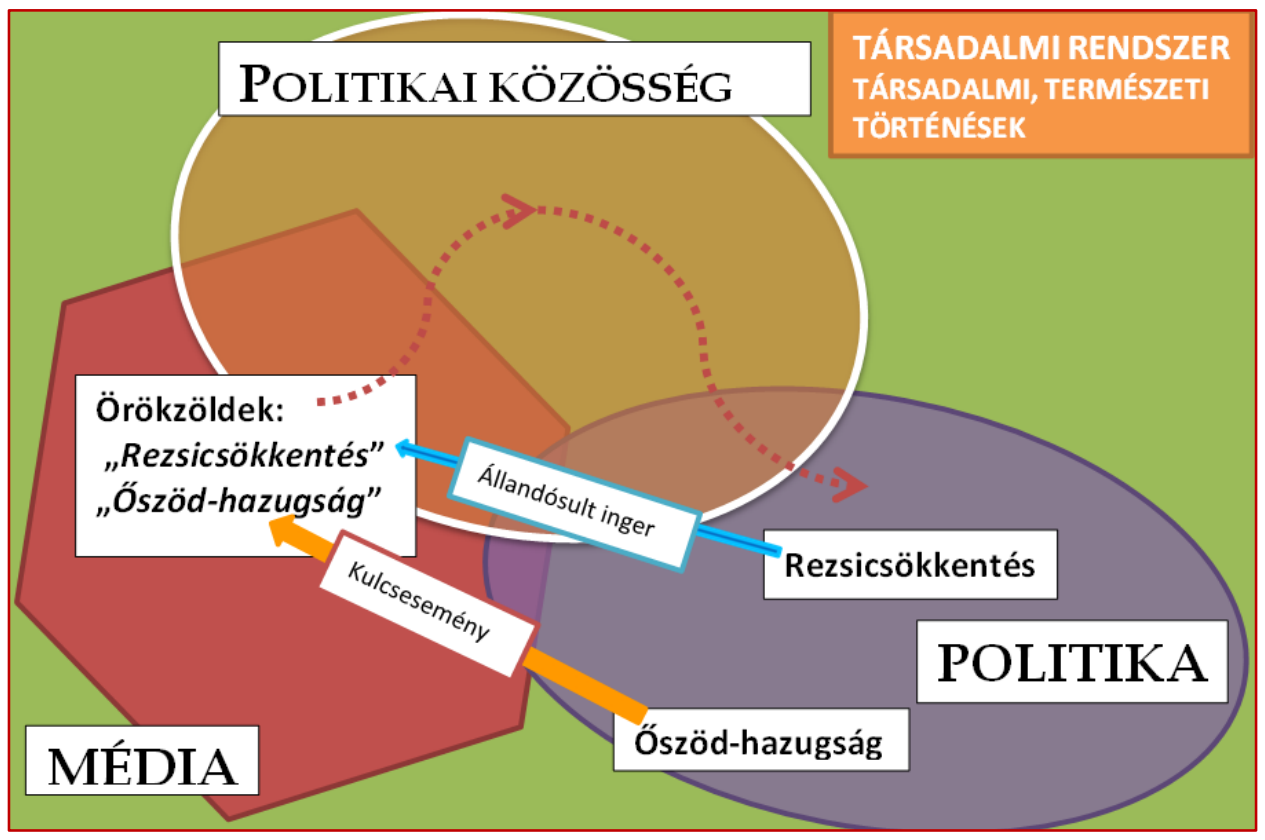

Az „Öszöd-hazugság” (a továbbiakban röviden „hazugság”), mint örökzöld közbeszédi téma egy a média szféráján kívülröl - a politikából - jött egyszeri, bár korántsem folytatás nélküli rendkívül erős inger - az őszödi beszéd napvilágra kerülésének - hatására kialakult kulcseseményre (Kepplinger 2007: 396) támaszkodik (16. ábra mustársárga nyíl). Ebben az esetben - hasonlóan ahhoz, ahogy a Watergate botrány, a 9/11-es New York-i terrortámadás, vagy az Olaszliszkai gyilkosság esetében is - a normasértés, a botrány által a publikumban kiváltott közös érintettség rendkívül erős érzése alapozta meg, hogy ez a közbeszédi téma állandó helyet vívott ki magának a tömegmédia témái között.

Referencia pontként müködő örökzölddé pedig az tette, hogy erkölcsi értékeléseket lehetett társítani hozzá. A tömegmédiának ugyanis ennyiben „fontos szerepe van az erkölcsök megőrzésében és újratermelésében. Ez persze nem úgy értendő, mintha képesek volnának etikai alaptételeket leszögezni, vagy akár a társadalom erkölcsi szintjét, a jó cselekvés irányában emelni. [...] Csak azt lehet a fülön csípett vétkeseken demonstrálni, hogy ilyen kritériumokra szükség van." (Luhmann 2008: 41)

A 17. ábra megerősíti, hogy az állandósult jelenlétü rituális témák és az örökzöldek médiadinamikailag megkülönböztethetetlenek. Az őszödi beszéd napvilágra kerülését megelőzően a „Hazugság” amennyire mindennapos, annyira hatás nélküli, állandósult jelenlétü rituális közbeszédi téma volt. A 2006 szeptemberében berobbant botrány által kiváltott hirtelen publikációs boom - a 17. ábrán piros pontok jelölik ezen időintervallum kezdetét és végét elmúlta után, a téma dinamikája ismét lineáris grafikonnal volt ábrázolható, de a fenti erkölcsi hatás miatt már egészen más kommunikációs szerepben jelent meg. Figyelemre méltó, hogy bár jelentősége fokozatosan csökkent, a téma utalásszerü referenciaként, az őszödi beszéd napvilágra kerülésének módja körüli eszmecsere jóvoltából még a 2014-es választási kampányban is elöbukkant. 
17. ábra

A „Hazugság” téma kapcsán az MNO portálon megjelent cikkek kumulatív száma

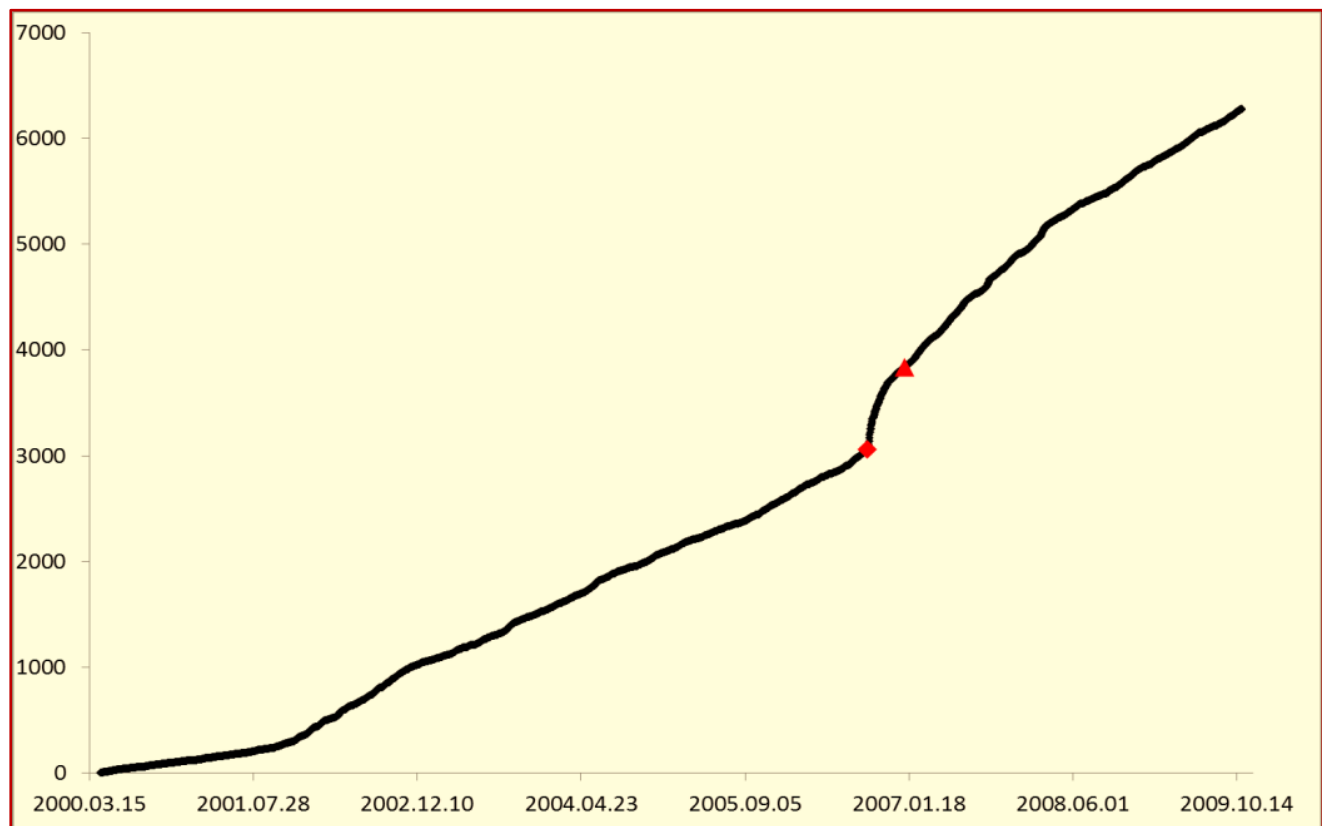

A fentiektől eltérő módon jött létre a „Rezsicsökkentés”, mint örökzöld közbeszédi téma. Ismert, hogy még 2013 legelején, tehát jóval a 2014-es kampányidőszak előtt, a kormány mintegy kísérleti jelleggel, egy egyszeri rezsicsökkentés mellett döntött. A kezdeményezés tehát a politika szféráján belül indult, majd ennek kedvező fogadtatását látva a kormánypárt, nyilvánvaló politikai szándékkal, tudatosan tervezett ismételt stimulusokkal érte el, hogy a tömegmédia végül is örökzöldként formálta meg a „Rezsicsökkentés” közbeszédi témát (18. ábra). Ebben az esetben tehát a társadalom egy másik alrendszeréből, a politika felől (16. ábra kék nyíl) a média alrendszerét folyamatosan érő ingerlés strukturális közbeszédi eredményével van dolgunk.

18. ábra

Rezsicsökkentéssel kapcsolatos cikkek kumulatív száma: $M N O, N O L$

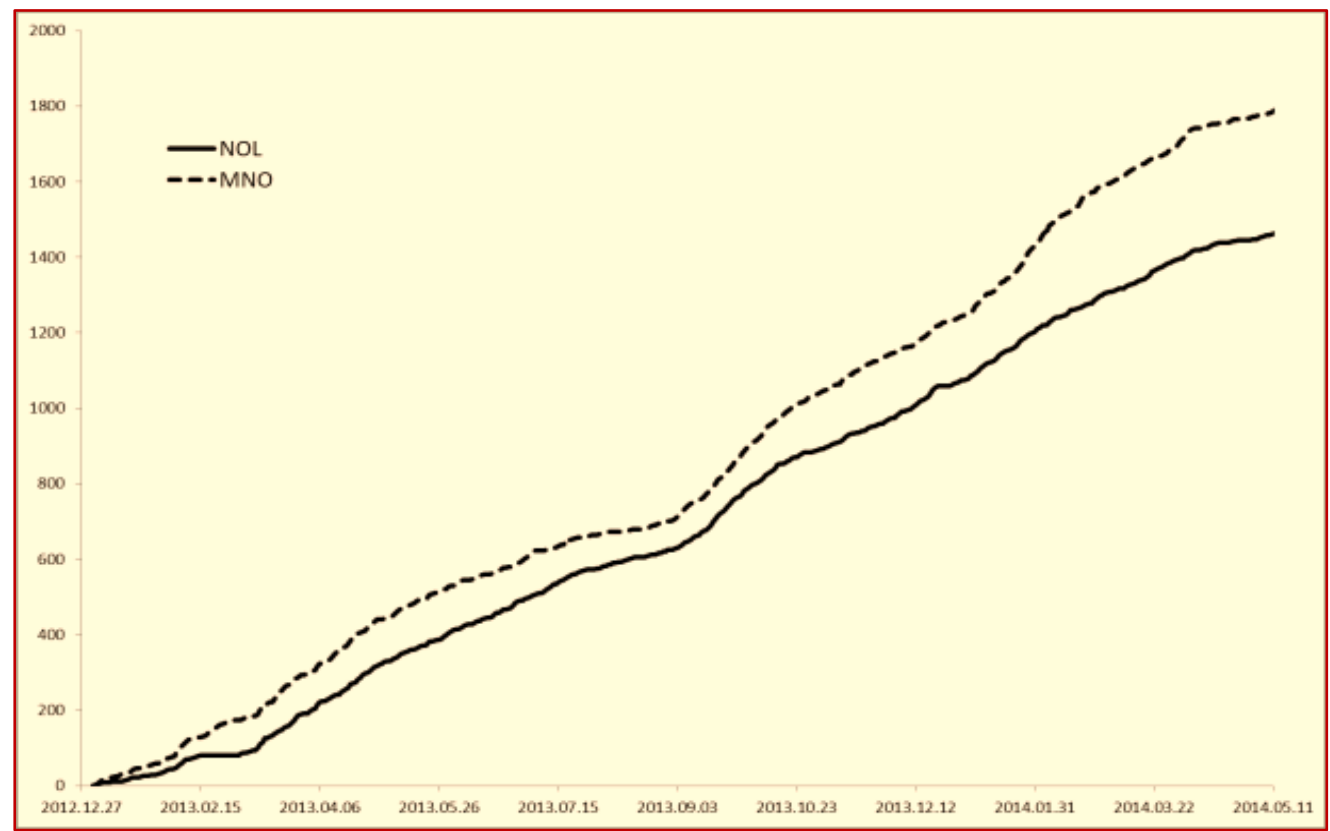


Szempontunkból a politika felöl érkező folyamatos ingerlésen túl, az örökzölddé válás döntő tényezője ezúttal is az erkölcsi elem, a lakossági terhek csökkentésének imperatívusza volt. Ez tette lehetetlenné, hogy a politikai szféra többi szereplöje kitérjen a téma elöl s ez a politika felöl érkező állandósult inger vezetett a téma örökzöldként történő rögzüléséhez.

\section{Hírfolyamok - botrányok}

Már eddigi példáink során is világossá válhatott, hogy az állandósult hírfolyamok kialakítására törekedve a média miért is részesíti előnyben a konfliktusos témákat. Mivel egy konfliktus során jó darabig nem ismertek a győztesek és a vesztesek, ezen „témáknak megvan az az elönyük, hogy a spontán létrejött bizonytalanságra játszanak rá." (Luhmann 2008: 38) Ez olyan feszültséget teremt, amely fenntarthatja a közönség folyamatos érdeklödését. Ezen belül különösen hatásosnak tünik a normasértések, s ezen belül is a botrányok szerepeltetése. Ez utóbbiakról szóló jelentésekkel a „tömegmédiumok képesek a leginkább kiváltani a közös érintettség és felháborodás érzését." (Luhmann 2008: 41)

Eddigi empirikus áttekintésünkböl látható volt az is, hogy számos fontos botránynak személyek adnak identitást, s ezek után magától értetődően beszélünk „Hagyó Miklós” vagy „Simon Gábor" ügyekről. A botrány ugyanis, mint közbeszédi típus, valamilyen normasértéshez köthető szenzáció. A normasértéshez pedig felelősök kellenek. Erre jó egy közbeszédi téma személyhez kötése. Másfelöl a ,személyek a társadalom számára egy ismeretlen jövő kézzelfogható szimbólumai. Egyrészt ismertek, [...] másrészt tudható, hogy ennek ellenére sem tudjuk, hogyan fognak cselekedni." (Luhmann 2008: 43) A személyek szerepeltetése révén a tömegmédia olyan történetet mesél el, amely „maga teremtette és folyamatosan megújított bizonytalanságot hoz létre, amely bizonytalanság további információkra van utalva. Önmaga keltette meglepetésekből, saját maga által felépített feszültségekböl él.” (Luhmann 2008: 64)

Leszállva most már az említési rangsorok legalsó régióiba, erősen változó dinamikájú témák egész sora tárul fel előttünk. A 2010-es kampányban ezt a szintet dominálja a rádiófrekvenciák ügye (19a-b. ábra). A „Class FM", „Danubius”, „Neo rádió,, „Sláger Rádió” kulcsszavakkal fémjelezhető témacsokrot a média először a két nagy párt közötti osztogatásként tálalta, majd később a Fidesz elleni támadásba fordította át. Itt bukkan fel a „,kötcsei beszéd" téma, amelyet a média egy része igyekezett Orbán Viktor őszödi önleleplező beszédeként megkonstruálni, s itt találhatjuk az „UD Zrt.”-féle lehallgatási botrányt, amelynek kapcsán egy a jobboldalon belüli törésvonalat igyekeztek felmutatni. A kampány legeslegvégén bukkant fel a Fidesz pártigazgatójának nevével fémjelzett úgynevezett „Kubatov botrány” illetve „Kubatov-lista”. 


\section{9(a-b). ábra}

19a) 2010 NOL: Sláger Rádió, Danubius Rádió, UD Zrt., Kubatov, rádiófrekvencia, Mádi, Dzsudzsák Balázs, Kötcse, Class FM, kötcsei beszéd, Neo rádió, Kubatov lista

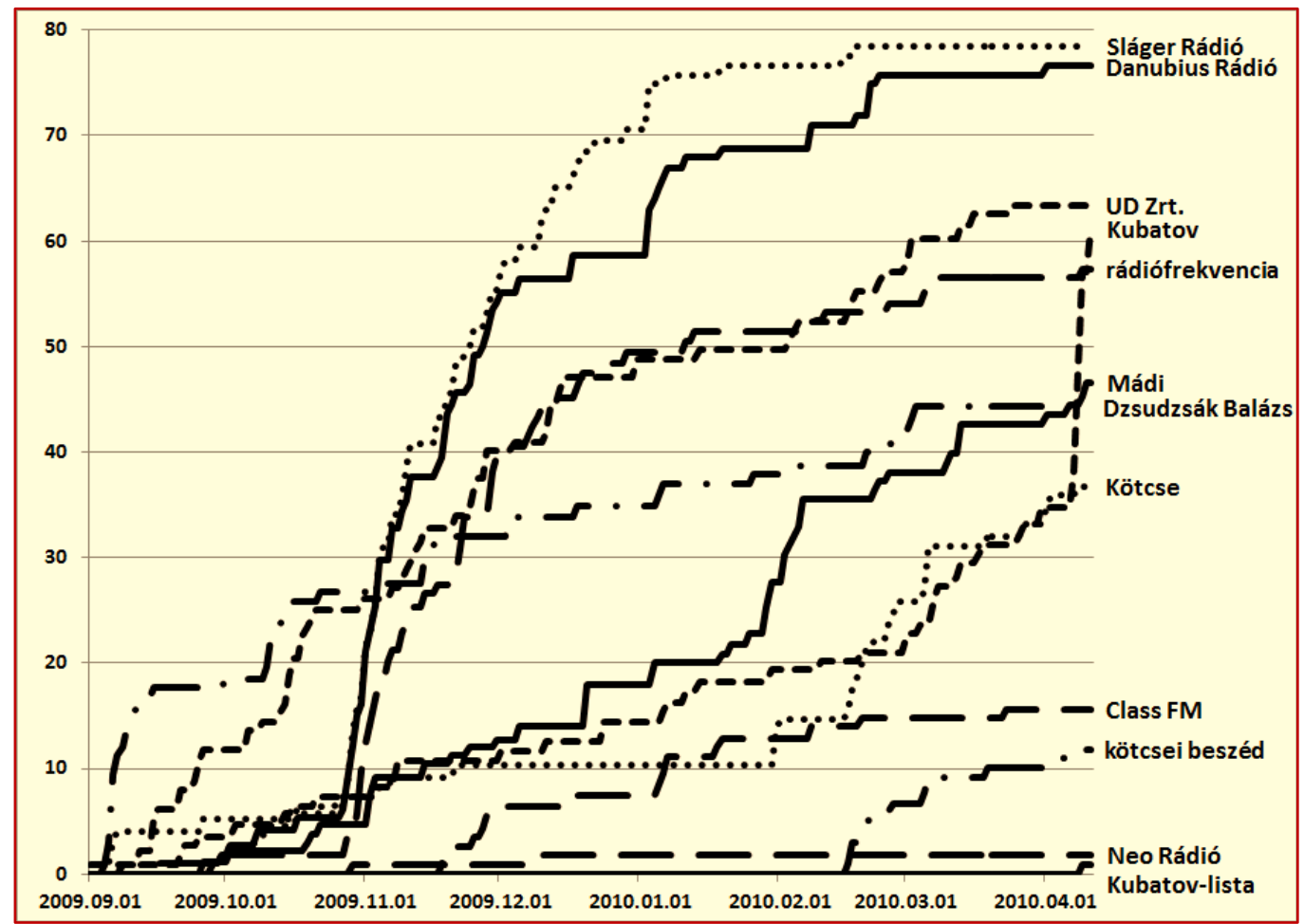

19b) 2010 MNO: Sláger Rádió, Danubius rádió, UD Zrt., Kubatov, rádiófrekvencia, Mádi, Dzsudzsák Balázs, Kötcse, Class FM, kötcsei beszéd, Neo rádió, Kubatov lista

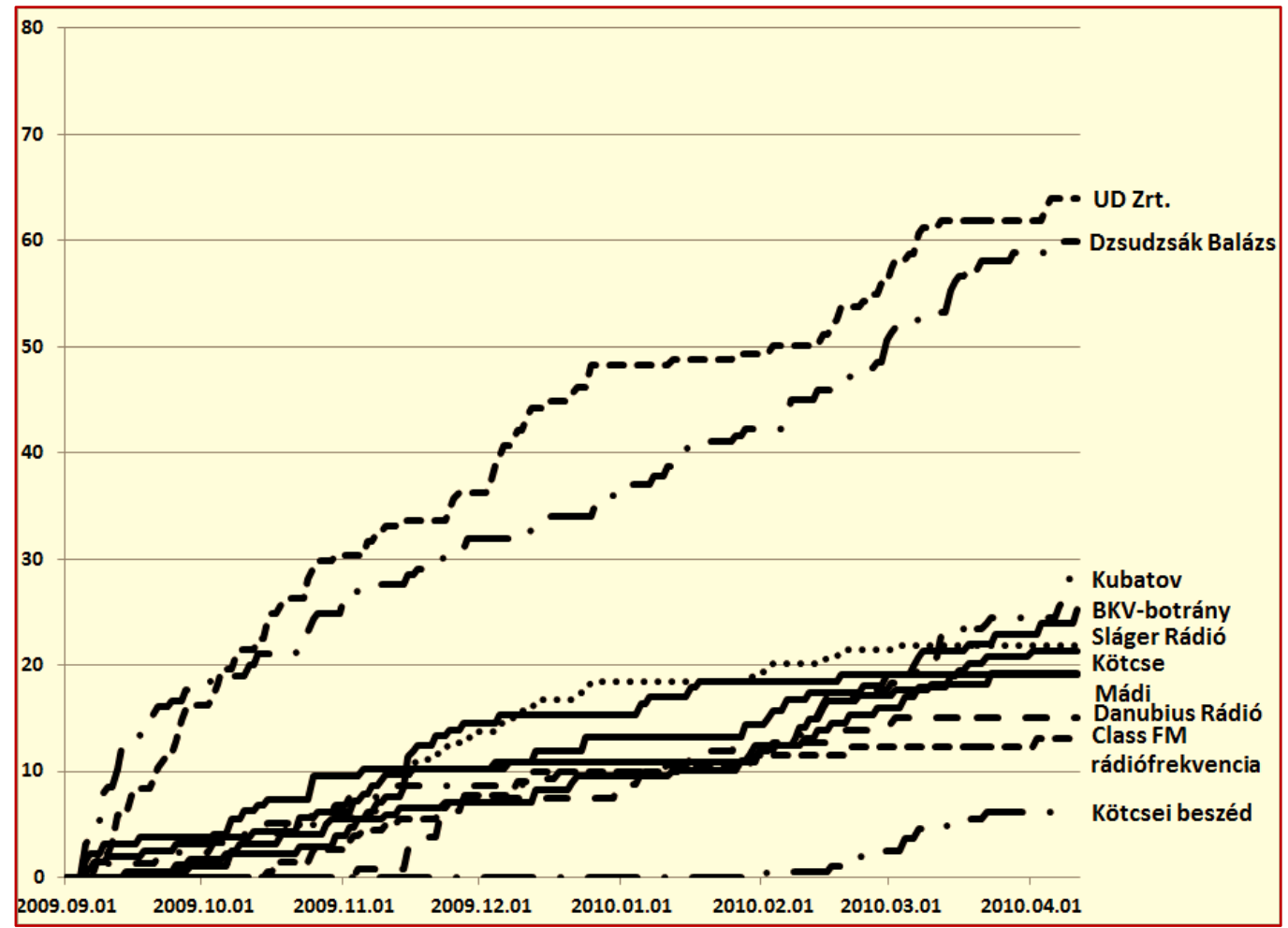


Tisztán kvantitatív alapon azt várnánk, hogy az 5 és 80 közötti tartományba eső, tehát tényleg rendkívül alacsony kumulatív említésszámaik miatt, ezek a témák a közönség számára teljességgel észlelhetetlenek maradtak. Ennek ellenére zajos botrányokként ragadtak meg közösségi emlékezetünkben.

\section{Kampánytémák dinamikája - botrányok mibenléte}

Ez az eredmény felveti a botrányok kvantitatív jellemezhetőségének igényét. Erre az adhat esélyt, hogy ezek a botrányszagú témák az állandósult jelenlétü rituális témáktól eltérően nagyon is időhöz kötöttek. Elöször is korántsem fogják át a kampányidőszak egészét. Nem biztos, hogy már az elejétől jelen vannak, s az is gyakran előfordul, hogy még a kampány vége elött kikerülnek a közbeszédből. Ezen túlmenően médiajelenlétük nagyon változékony intenzitású. Hirtelen fellobbanások és stagnáló időszakok váltják egymást előre jelezhetetlen szabálytalanságban.

Indexek sokaságával próbálkoztunk. A legkézenfekvőbb mérőszámok, mint például az egyes témákkal kapcsolatos napi relativ-cikkszámok változása, e változások témánkénti összegezése, vagy a témák e változás sorrend szerinti rangsora nem vezettek semmilyen eredményre.

Miután láttuk, hogy a botrányok rendszerint nem a kampányidőszak elejétől vannak jelen a közbeszédben, meghatároztuk azt is, hogy mikor és a teljes kumulatív relatív-cikkszámhoz képest mekkora lépéssel lépnek be az egyes témák. A botrányok változékonyságának mutatószámához azonban úgy is eljuthatunk, ha az egyes témák napi relatív-cikkszámai változását az adott téma teljes időszakra számított kumulatív relatív-cikkszámához viszonyítjuk. Az egyes témák „volatilitását” az így kapott idősorok szórásával, maximumával, minimumával és terjedelmével mértük.

Általános tapasztalat volt, hogy az indexek segítségével egyes botrányos témák kiemelhetők ugyan az állandósult jelenlétü rituális témák tengeréből, de továbbra is szétválaszthatatlanul keverednek bizonyos nem botrányos újdonságokkal.

A sokféle indexgyártási kísérlet illusztrációjaként az egyik legsikeresebbet mutatjuk be a 20. ábrán. Egy téma relatív, önmagához mért intenzitását mérhetjük az adott témára vonatkozó teljes említés szám 10\%-ról a 90\% eléréséig eltelt idő hosszával. Ha eszerint rakjuk sorba a témákat, akkor az idő rövidsége az egyes témák életciklusának intenzitását méri. Az itt látott diagram is azt mutatja, hogy a botrányok egy része (ezeket pirossal jelöltük) kiemelkedik a témák tengeréből, nem lehet azonban egyértelmüen elkülöníteni őket az erősen fókuszált aktualitással bíró témáktól. 
20. ábra

2010 MNO: Közbeszédi témák a napokban mért saturációs idő sorrendjében

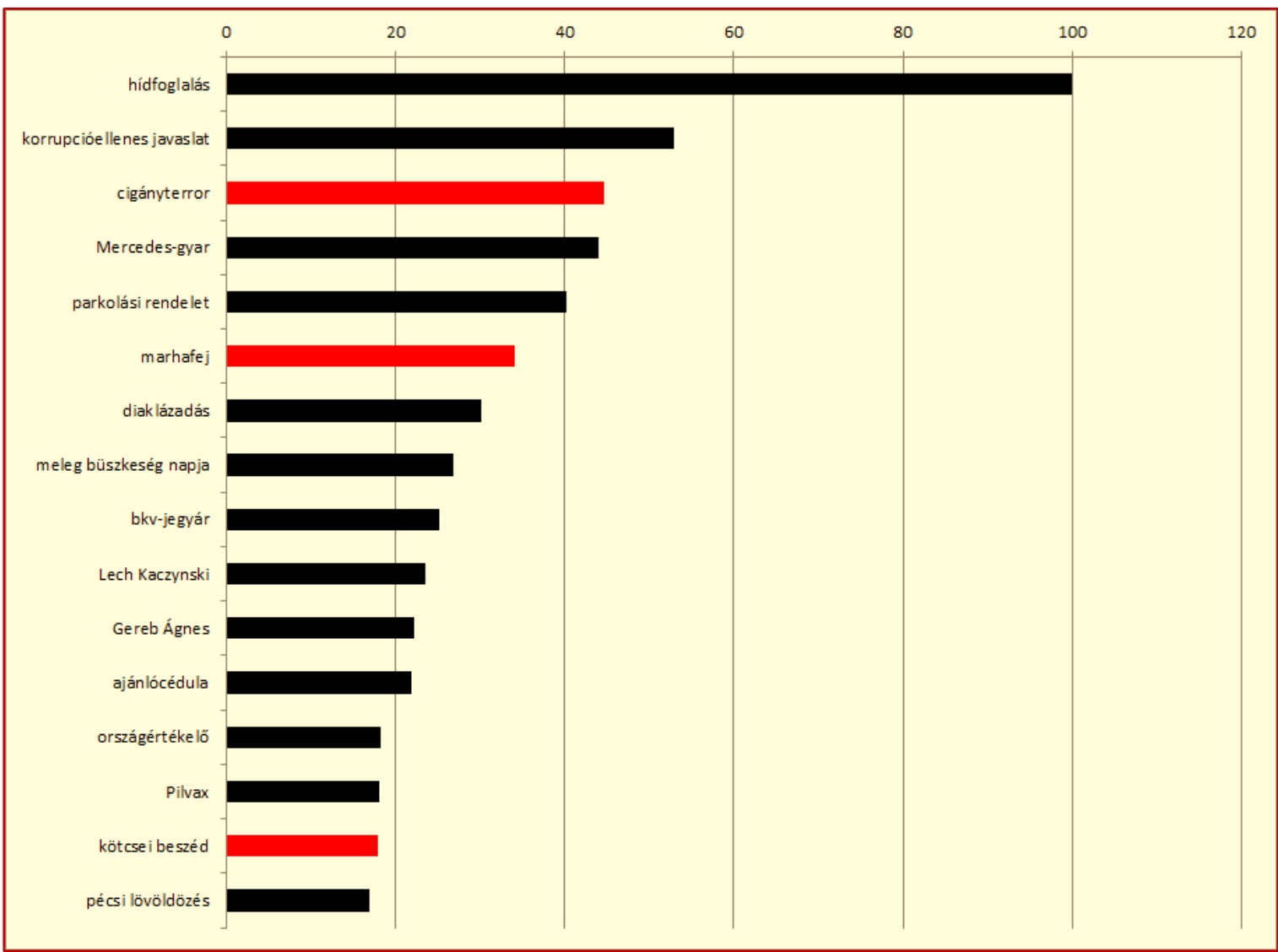

Láthatóan egy botrány mibenléte nem tisztán kvantitatív kérdés. Ez tulajdonképpen világos, hiszen nyilvánvalóan nincs botrány az adott eseményt botrányosnak tartó publikum nélkül. Ahogy egy regény olvasói vagy egy szappanopera nézői kizárt harmadikként részesei egy történetnek, úgy egy közbeszédi téma involválódó megfigyelőiként a publikum is része a botránynak. A botrányok kutatását ezért két irányban lehetne kiteljesíteni. Egyrészt a publikumra vonatkozó követő vagy introspektív vizsgálatokkal tárhatjuk fel az egyes közbeszédi témák hatásmechanizmusát. Másrészt empirikusan megragadható, hogy a média miként formál meg egy eseményt annak érdekében, hogy a publikumot érintettként bevonja bizonyos botrányként felkínált eseményekbe. Mindkét irány azonban meghaladja a jelen tanulmány kereteit.

\section{Botrányok és valóságkonstrukció}

Visszatérve most a botrányok dinamikájának kvantitatív elemzésére, a 2014-es kampányban a száz kumulatív említés alatti tartományban (21a-b. ábra) találjuk az „áfacsalás” témáját, amely a vizsgált két médiumban nagyon hasonló időbeli dinamikát követ. A másik médiumbeli helyzetéhez képest a NOL esetében ide szorult le a „,bajai videó”, itt jelent meg a „Közgép”, míg az MNO esetében itt bukkan fel a „szobordöntés”. Mindkét médiumban ezen alacsony említésszám alatt jelennek meg a „Veritas”, a „Szakály Sándor” és a „Megszállási Emlékmü"' egymással összefonódó, zajosan tárgyalt, botrányosnak kezelt közbeszédi témái. Az említésszámok tekintetében azonban erős szerkesztőségi szelekció érvényesült, mert ezek jelentősen és szisztematikusan eltérnek egymástól. A NOL-on a kumulatív relatív-cikkszámok 89, 70, 93 rendre jóval nagyobbak, mint az MNO esetében mért 14, 11, 28. 


\section{1(a-b). ábra}

21a) 2014 NOL: áfacsalás, Közgép, Megszállási Emlékmü, Veritas, bajai videó, Szakály Sándor, stadionépités

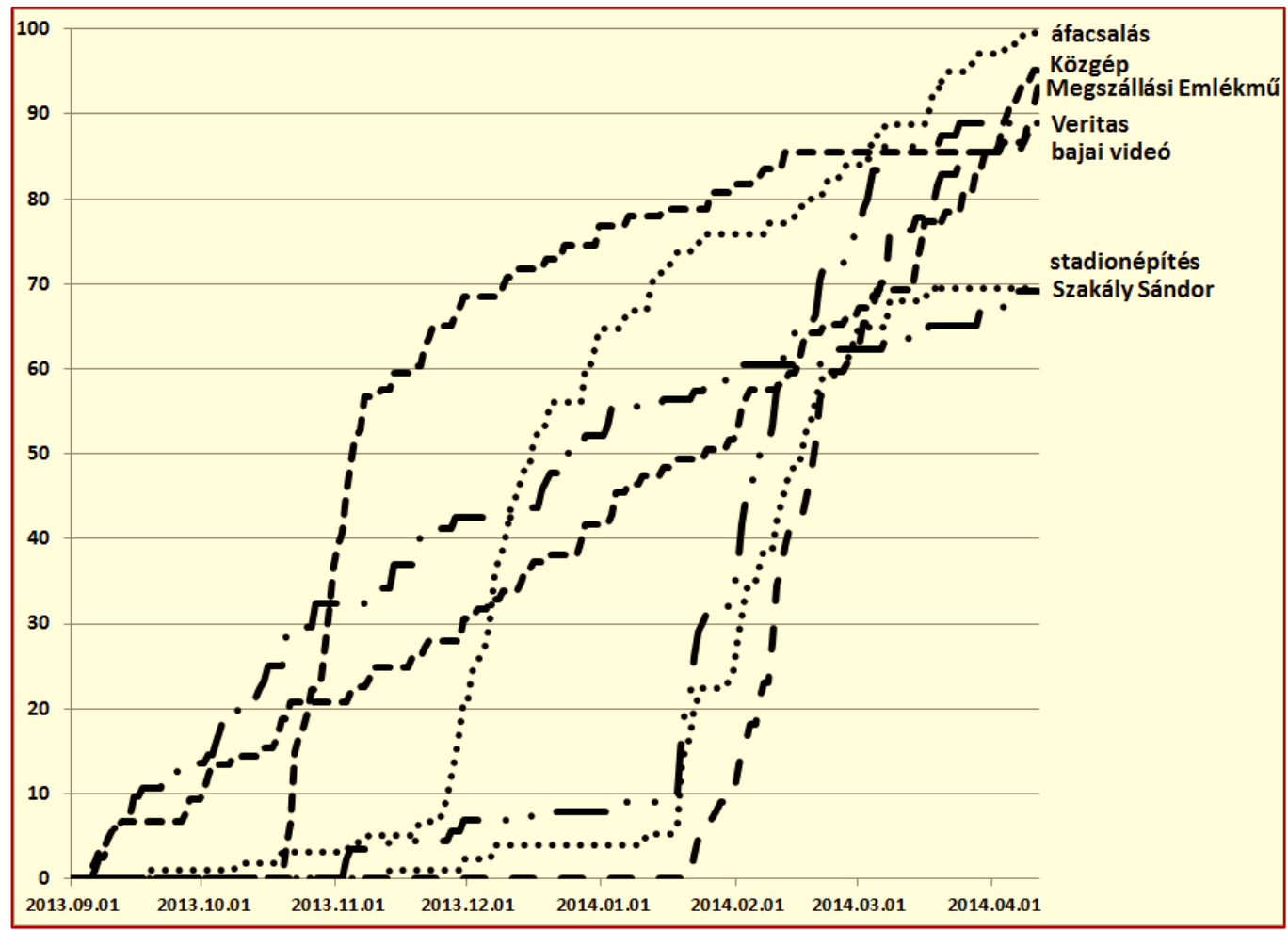

21b) 2014 MNO: szobordöntés, áfacsalás, Megszállási Emlékmü, Veritas, Szakály Sándor (jobboldalt)

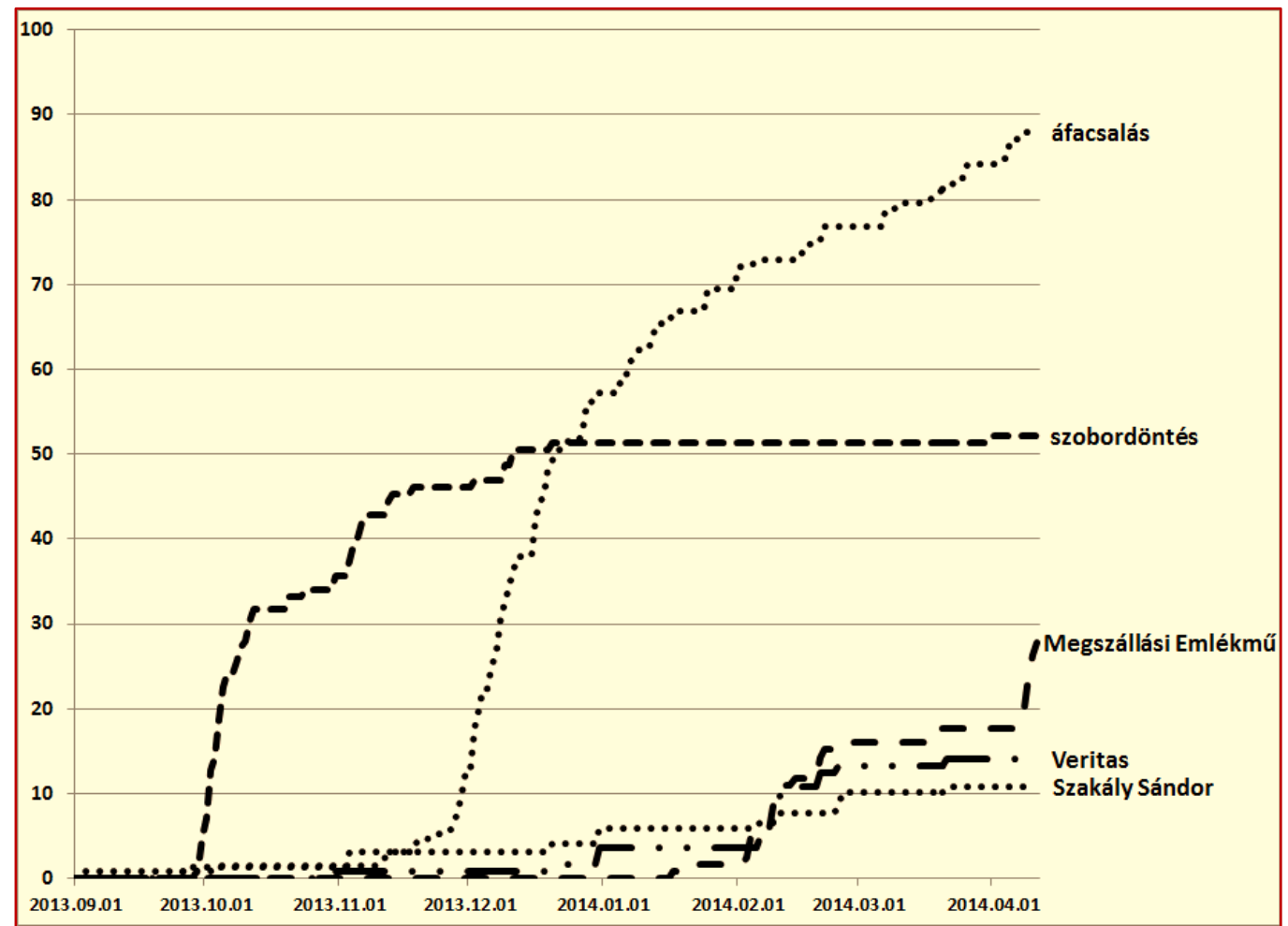


2014-ben mindkét médiumban a rendkívül alacsony, 35 említés alatti tartományban (22a-b. ábra) találhatók a „HAHA” és a „Hallgatói hálózat” egykor sokat emlegetett közéleti témái. Kifejezetten a kampányra időzítve, igazán zajos botrányként, de mindkét médiumban ezen a nagyon alacsony említési szinten jelentek meg a „Kishantos”, „,trafikpályázat”, „paksi szerzödés” kampánytémák. A 2010-es kampányidőszakra utal vissza „Kötcse” témája. A másik médiumhoz képest a NOL esetében ide szorult le a „szobordöntés”, míg az MNO esetében a „stadionépités” és a „Közgép”. A „Rogán vagyonnyilatkozata” hívószavú téma pedig a NOL-on mindössze egyetlen említéssel a mérhetőség alsó határán van, míg az MNO-on meg sem jelenik.

22(a-b). ábra

22a) 2014 NOL: trafikpályázat, Kishantos, hallgatói hálózat, szobordöntés, Kötcse, paksi szerzödés, HAHA, Rogán vagyonnyilatkozat (jobboldalt)

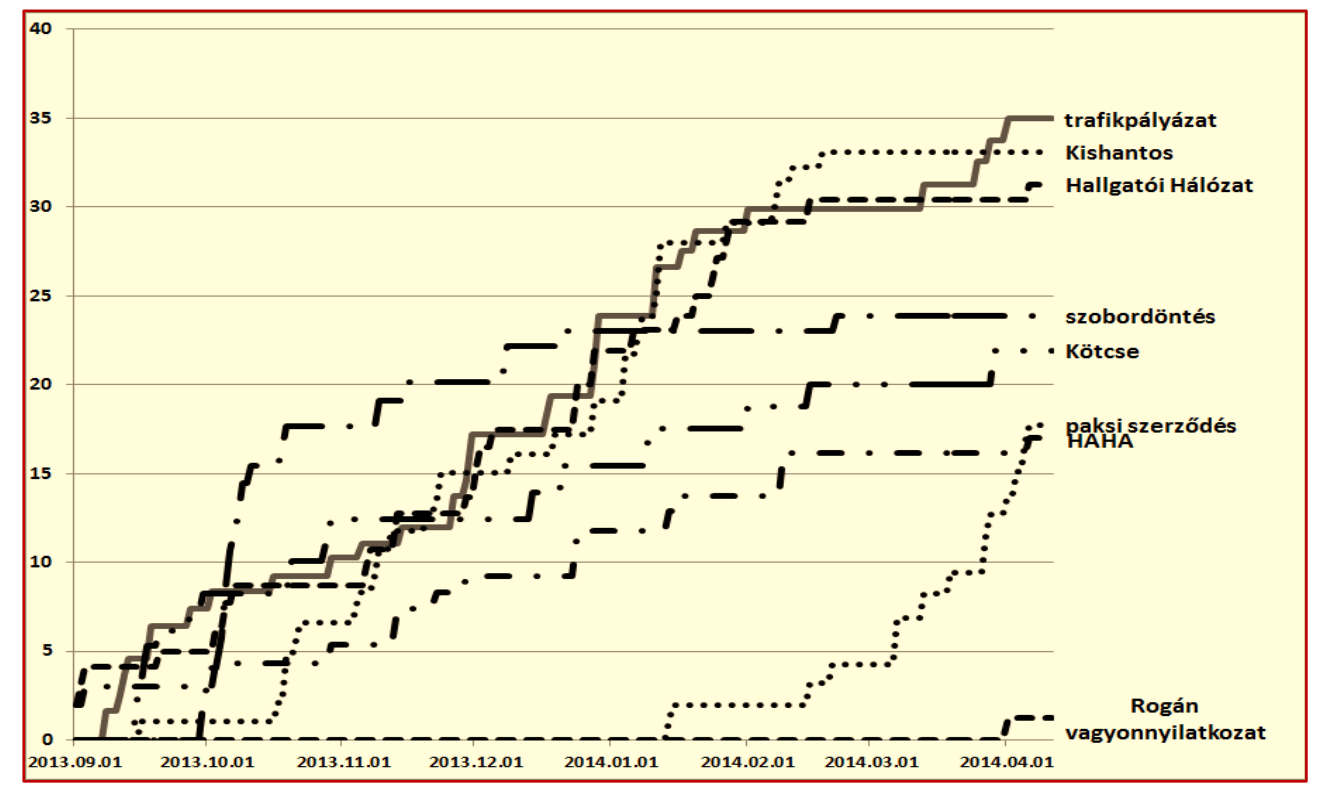

22b) 2014 MNO: stadionépités, hallgatói hálózat, HAHA, paksi szerzödés, Kötcse, Kishantos, Közgép, trafikpályázat

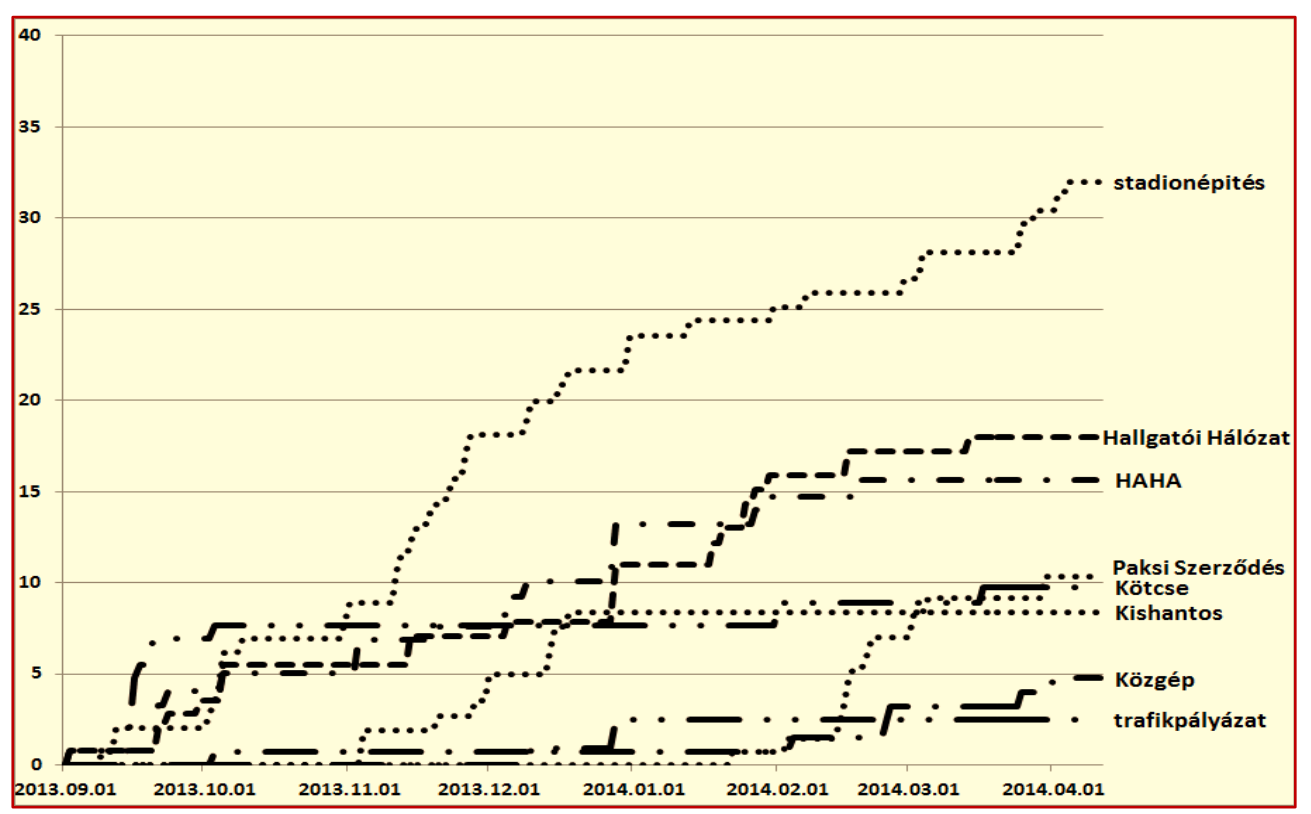


Mivel a legutóbbi fejtegetésekben egyre hangsúlyosabban jelent meg a szerkesztőségi szelekció hatása a hírfolyamok formálásában, ezen a ponton egyre indokoltabbá válik a kérdés, hogy tényleg úgy vannak-e a dolgok, ahogy arról a média beszámol? A megfigyelhetö szerkesztőségi szelekció láttán, nem merülhet-e fel a politikai-ideológiai preferenciákra alapozott politikai, esetleg gazdasági távirányítás lehetősége?

A kampányidőszak alapstruktúrájának elemzése során erőteljesen hangsúlyoztuk, hogy a szerkesztőségi szelekció ott alig érzékelhető, a botrányok esetében azonban, úgy tünik, más a helyzet. Ennek pontosabb detektálására 2010-re és 2014-re is a teljes kumulatív említésszámok alapján mindkét médiumban sorba raktuk a vizsgált közbeszédi témákat. Az MNO-on kapott helyezésszámból kivontuk a NOL-beli helyezésszámokat, majd a témákat e különbségek szerint rangsoroltuk. A nagy pozitív értékek azt jelentik, hogy az adott téma az MNO-on mennyivel hátrébb, a negatív értékek pedig, hogy mennyivel elörébb helyezkedik el az említésrangsorban.

Nehéz arról objektív ítéletet mondani, hogy a helyezésrangsorokban mekkora különbséget tekinthetünk jelentősnek. A 23. és 24. ábrákon elemi statisztikai megfontolások alapján a $20 \%$-nál nagyobb helyezés rangsorbeli eltéréseket mutató témákat ábrázoljuk. ${ }^{12}$ Ezen témák száma a 2010-ben elemzett 117 és a 2014-ben vizsgált 239 témához viszonyítva rendre 6\% illetve 5\%, tehát jelentéktelennek mondható.

23. ábra

Kumulativ emlités helyezésrangsorok eltérése 2010

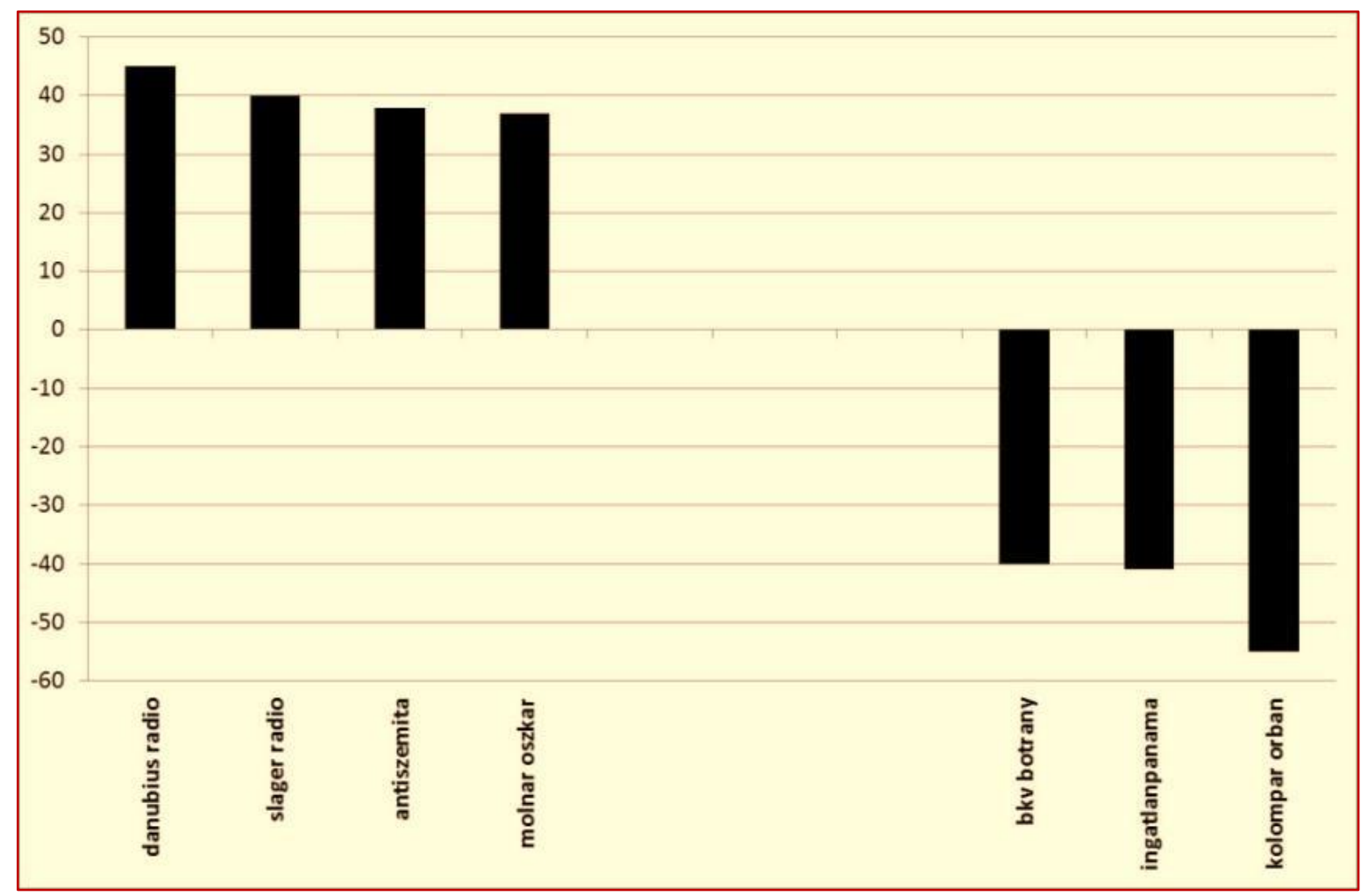

${ }^{12}$ Mivel a helyezésrangsorok eltérése esetében nulla átlagú, csaknem szimmetrikus eloszlással van dolgunk, a fenti kritérium lényegében megegyezik azzal az elvárással, hogy a két szórásnyinál nagyobb eltéréseket tekintjük jelentőseknek. 
24. ábra

Kumulativ-emlités helyezésrangsorok eltérése 2014

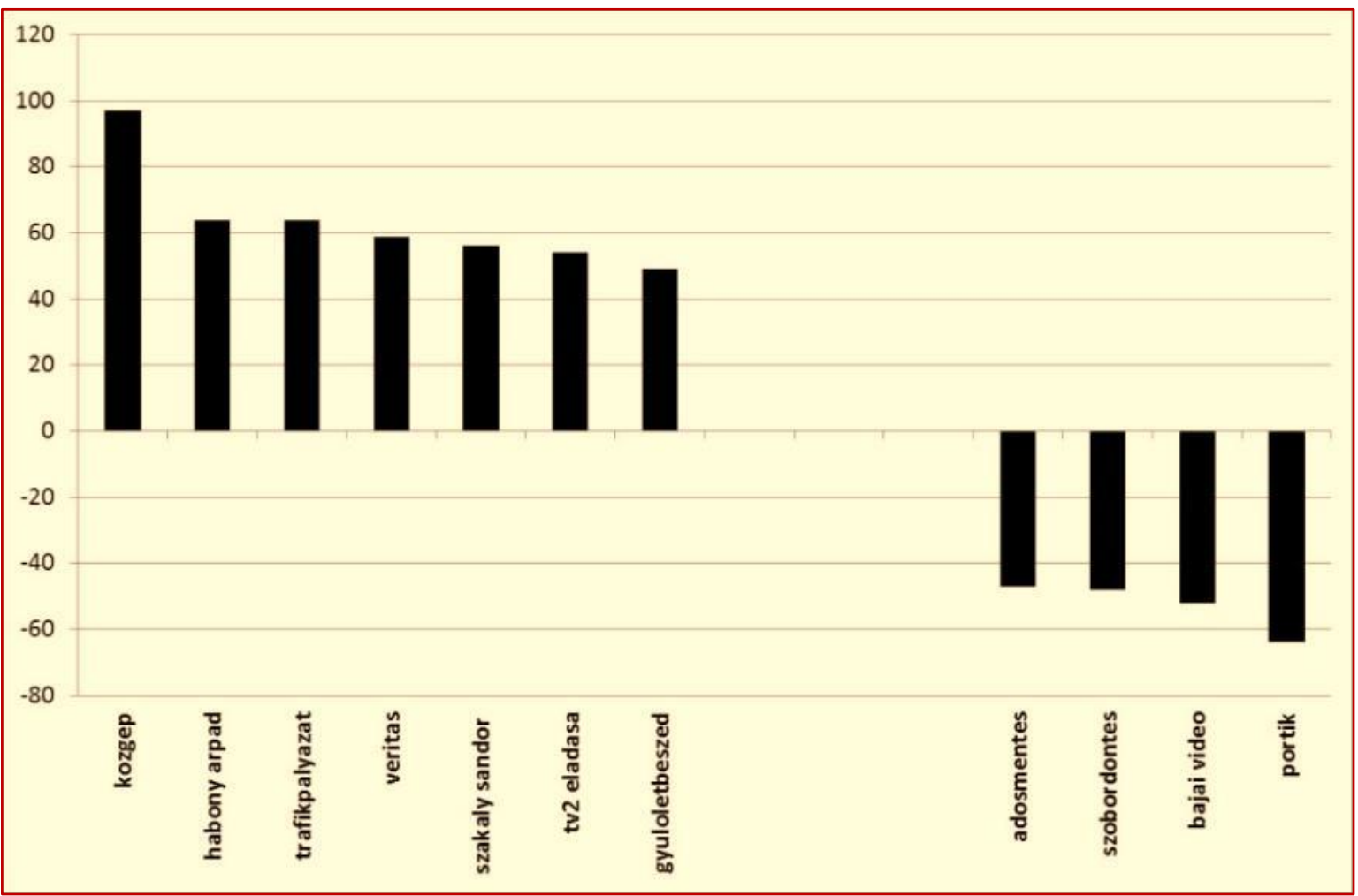

Más a helyzet azonban, ha arra gondolunk, hogy a 2014-ben megfigyelt mintegy két tucat politikai médiabotránynak lényegében a fele a kumulatív említésszámok tekintetében a két médium részéről egészen más bánásmódban részesül. Ráadásul a „Közgép”, „Habony Árpád”, „,trafikpályázat”, „,Veritas”, „,Szakály Sándor”, „TV2 eladása”, valamint az „,adósmentés”, „szobordöntés”, „,bajai videó”, „Portik” témák egyértelmű politikai színezettel rendelkeznek, esetükben tehát nyilvánvalóan politikai preferenciák szerinti szerkesztőségi szelekcióval van dolgunk. ${ }^{13}$

Az ilyen helyzetek miatt merülhet fel rendre az a gyanú, hogy a dolgok nem feltétlenül vannak úgy, ahogy azokról a média beszámol, s hogy az egyes médiumok esetenként, a tömegmédia pedig amúgy általában is eltorzítja a valóságot, egyszóval „manipulál’”.

A manipulációs vád legsúlyosabb változata, amikor a médiáról egyenesen azt feltételezik, hogy „politikai vagy vallási, vagy újabban katonai irányultságú távirányításnak” (Luhmann 2008: 34) alávetve müködik. Persze a „,kifejezetten politikai jellegü részrehajlás” (Luhmann 2008: 161) eredhet a szerkesztőségen belülről is. Jeffrey Alexander, például, a nyugati média kapcsán egyenesen úgy ítélte meg, „hogy a hírekben kifejezésre jutó értékítéletek sokkal inkább a riporterek szocializált értékorientációjának, mint a médiatulajdonosok irányításának következményei." (Luhmann 2008: 166)

De akkor ez már nem is lenne manipuláció? Legalábbis addig nem, amíg megfelel bizonyos szakmai követelményeknek? Csakhogy a hírek nem egyszerüen közlö, hanem inter-

${ }^{13}$ Hangsúlyoznánk, hogy itt a relatív pozíciók eltéréséről van szó. A teljes kumulatív relatív cikkszámok tekintetében ezek a témák igen-igen csekély súlyt képviselnek. Láttuk például, hogy a kumulatív-említés helyezésrangsorok eltérése a „Habony Árpád” közbeszédi téma esetében kiugróan magas volt. Mindeközben azonban ez a téma mindkét médium esetében igen alacsony, az MNO esetében nulla, míg a NOL-on is csak 23 teljes kumulatív említésszámmal szerepelt. 
pretáló és magyarázó, ennyiben talán „manipulatív” funkciója megmutatkozik „abban a szigorú szakmai követelményrendszerben, amit az újságírók a hírekkel kapcsolatban megfogalmaznak. A nagyobb hírügynökségek elöírásai mind egybehangzóak abban a tekintetben, hogy erősen hangsúlyozzák az egyszerü, közérthető stílus fontosságát. Ennek az egyszerüségnek az oltárán azonban szükségszerüen föláldoznak számos mozzanatot, tehát arra kényszerülnek, hogy csak a legfontosabb részleteket emeljék ki.” (Luhmann 2008: 162)

Fenti fejtegetéseinkkel mintha visszakanyarodtunk volna az eseményképzés, valamint a hír/nem hír szelekció tanulmányunk legelején felvetett kérdésköréhez. Ahhoz viszont, hogy túllépjünk az ott elmondottakon, ezt a szelekciót a továbbiakban már nem a szerkesztőségek választási szabadsága szempontjából, hanem Luhmann nyomán a tömegmédia, mint a modern társadalom egyik funkció szerint differenciált alrendszere működésmódja és valóságkonstrukciója felöl kellene megközelítenünk. Ez azonban egy másik önálló tanulmány feladata lesz.

\section{1. Összefoglalás}

Tanulmányunkban a vizsgált közbeszédi témákat három szempont szerint különböztettük meg. Az alapstruktúrát alkotó témák időtlen dinamikájúak, érdemi szerkesztőségi szelekció alig-alig figyelhető meg. Ezen állandósult jelenlétü rituális témákon belül a publikum érintettsége alapján különítjük el az úgynevezett örökzöld témákat. Az időhöz kötött - látható kezdő és végponttal, valamint változó dinamikával rendelkező - közbeszédi témákat aktualitásoknak nevezzük. Mivel az alkalmilag rendre ismétlődő témák, például az évfordulók is szert tehetnek pillanatnyi aktualitásra, ezen a kategórián belül megkülönböztethetjük az újdonságokat. A tömegmédia müködésében alapvető szerepet játszó botrányokat a publikum érintettsége alapján különíthetjük el. (25. ábra)

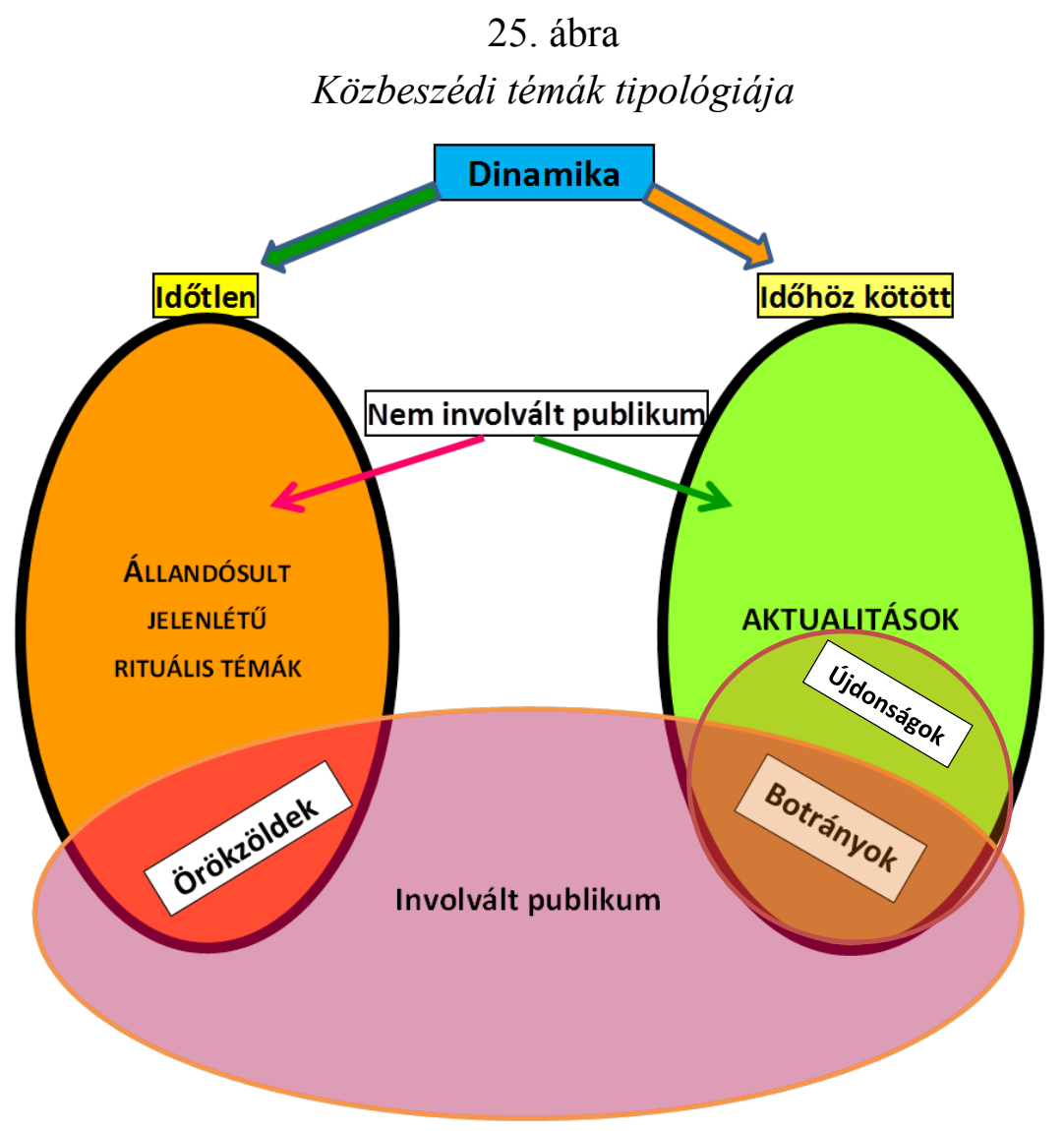




\section{Irodalom}

Alexander, Jeffrey (2007) A tömegmédia rendszerszemlélete történelmi és összehasonlító nézőpontból. In: Angelusz, Róbert - Tardos, Róbert - Terestyéni, Tamás (2007 szerk.) Média, nyilvánosság, közvélemény. Budapest, Gondolat Kiadó. 157-168.

Bandy, Alex (2014) A csokoládé gyilkosság. Budapest, Akadémiai Kiadó.

Baumgartner, Frank - Jones, Bryan (1993) Agendas and instability in American Politics. Chicago. University of Chicago Press.

Baumgartner, Frank - Jones, Bryan (2002) Policy Dynamics. Chicago, University of Chicago Press.

Baumgartner, Frank - Jones, Bryan (2004) Representation and Agenda-setting. Policy Studies Journal, 2004/1. 1-24.

Dearing, James - Rogers, Everett M. (1996) Agenda-setting. Thousand Oaks: Sage.

Fokas, Nikos (2008) Evergreens, sensations and the rest. A quantitative analysis of dynamics of news articles on domestic politics. Review of Sociology, Vol. 14. 2008 I. 5-24.

Fokas, Nikos - Kopper, Ákos (2012) Sensations, Evergreens in the Media and Social Memory, Watergate scandal, $9 / 11$ and others as places and milieus of remembering. Review of Sociology, 2012/4. 17-33.

Fokasz, Nikosz - Kopper, Ákos (2015) Média, emlékezés, identitás In: Bodor Péter (szerk.) Emlékezés, identitás, diskurzus. Budapest, L'Harmattan. (Előkészületben)

Görke, Alexander - Scholl, Armin (2006) Niklas Luhmann's Theory of Social Systems and Journalism Research. Journalism Studies, 2006/4. 644-655.

Kepplinger, Hans Matthias (2007) A kommunikációtudományi jelenségfogalom. In: Angelusz, Róbert - Tardos, Róbert - Terestyéni, Tamás (2007 szerk.) Média, nyilvánosság, közvélemény. Budapest, Gondolat Kiadó. 391-412.

Luhmann, Niklas (2008) A tömegmédia valósága. Budapest, Gondolat-AKTI.

Manheim, Jarol B. (1986) A model of agenda dynamics. In: McLaughlin, Margaret (1986ed.) Communication yearbook 10. Newbury Park, Sage. 499-516.

McCombs, Maxwell - Shaw, Donald (1991) A tömegmédia témakijelölő funkciója. In: Angelusz, Róbert - Tardos, Róbert - Terestyéni, Tamás (2007 szerk.) Média, nyilvánosság, közvélemény. Budapest, Gondolat Kiadó. 252-260.

Molotch, Harvey - Lester, Marilyn (2007) A hír mint célirányos viselkedés In: Angelusz, Róbert - Tardos, Róbert - Terestyéni, Tamás (2007 szerk.) Média, nyilvánosság, közvélemény. Budapest, Gondolat Kiadó. 413-432.

Nora, Pierre (1999) Emlékezet és történelem között. A helyek problematikája. Aetas, 1999/3. $142-157$.

Rogers, Everett M. - Kincaid, D. Lawrence (1981) Communication Networks. New York, The Free Press.

Sándor, Péter - Vass László (2010szerk.) Magyarország politikai évkönyve 2009-röl [Elektronikus dokumentum]. Budapest, Demokrácia Kutatások Magyar Központja Alapítvány.

Sándor, Péter - Vass László (2011szerk.) Magyarország politikai évkönyve 2010-röl [Elektronikus dokumentum]. Budapest, Demokrácia Kutatások Magyar Központja Közhasznú Alapítvány. 
Szabó, Gabriella - Mihályffy, Zsuzsanna - Kiss, Balázs (2011szerk.) Kritikus kampány: A 2010-es országgyülési kampány elemzése. Budapest, L'Harmattan.

Török, Gábor (2005) A politikai napirend. Budapest, Akadémiai Kiadó.

Weber, Stefan (szerk.) 2010[2003] Theorien der Medien. Von der Kulturkritik bis zum Konstruktivismus. Stuttgart, UTB. 